\title{
Anaplasma phagocytophilum-a widespread multi-host pathogen with highly adaptive strategies
}

\author{
Snorre Stuen $^{1 *}$, Erik G. Granquist ${ }^{2}$ and Cornelia Silaghi ${ }^{3}$ \\ 1 Department of Production Animal Clinical Sciences, Norwegian School of Veterinary Science, Sandnes, Norway \\ 2 Department of Production Animal Clinical Sciences, Norwegian School of Veterinary Science, Oslo, Norway \\ ${ }^{3}$ Department of Veterinärwissenschaftliches, Comparative Tropical Medicine and Parasitology, Ludwig-Maximilians-Universität München, Munich, Germany
}

Edited by:

Agustín Estrada-Peña, University of

Zaragoza, Spain

Reviewed by:

Lee-Ann H. Allen, University of

lowa, USA

Jason A. Carlyon, Virginia

Commonwealth University School of

Medicine, USA

${ }^{*}$ Correspondence:

Snorre Stuen, Department of

Production Animal Clinical Sciences,

Norwegian School of Veterinary

Science, Kyrkjeveien 332/334,

N-4325 Sandnes, Norway

e-mail: snorre.stuen@nvh.no
The bacterium Anaplasma phagocytophilum has for decades been known to cause the disease tick-borne fever (TBF) in domestic ruminants in Ixodes ricinus-infested areas in northern Europe. In recent years, the bacterium has been found associated with Ixodes-tick species more or less worldwide on the northern hemisphere. A. phagocytophilum has a broad host range and may cause severe disease in several mammalian species, including humans. However, the clinical symptoms vary from subclinical to fatal conditions, and considerable underreporting of clinical incidents is suspected in both human and veterinary medicine. Several variants of $A$. phagocytophilum have been genetically characterized. Identification and stratification into phylogenetic subfamilies has been based on cell culturing, experimental infections, PCR, and sequencing techniques. However, few genome sequences have been completed so far, thus observations on biological, ecological, and pathological differences between genotypes of the bacterium, have yet to be elucidated by molecular and experimental infection studies. The natural transmission cycles of various $A$. phagocytophilum variants, the involvement of their respective hosts and vectors involved, in particular the zoonotic potential, have to be unraveled. A. phagocytophilum is able to persist between seasons of tick activity in several mammalian species and movement of hosts and infected ticks on migrating animals or birds may spread the bacterium. In the present review, we focus on the ecology and epidemiology of $A$. phagocytophilum, especially the role of wildlife in contribution to the spread and sustainability of the infection in domestic livestock and humans.

Keywords: Anaplasma phagocytophilum, ecology, epidemiology, distribution, hosts, vectors

\section{INTRODUCTION}

The bacterium Anaplasma phagocytophilum has been known to cause disease in domestic ruminants (Europe) (Foggie, 1951) and horses (USA) (Gribble, 1969) for decades. More recently, the infection has been detected in several mammalian species, including humans, in areas on the northern hemisphere with endemic occurrence of Ixodes ticks. A. phagocytophilum as a bacterial species appears to be a generalist, infecting a wide range of animals. Multiple genetic variants of the bacterium have been characterized (Scharf et al., 2011) and subpopulations within the species are now being discussed. In this review, we present updated information especially concerning the ecology and epidemiology of A. phagocytophilum.

\section{HISTORY}

During an experimental study on louping-ill (LI) in Scotland last century, some sheep contracted an unknown fever reaction on tick-infested pastures. The fever reaction was transmitted to other sheep by blood inoculation, but gave no protection against a later LI-virus infection. The disease was given the provisional name "tick-borne fever" (TBF), and the responsible pathogen was assumed to belong to the class Rickettsia (Gordon et al., 1932,
1940). The name TBF is still used for the infection in domestic ruminants in Europe. Anecdotally it could be mentioned that the Norwegian synonym of TBF is "sjodogg," and this name was already used to describe a devastating illness in ruminants as early as year 1780 in a coastal area of western Norway (Stuen, 2003).

The causative agent of TBF was first classified as Rickettsia phagocytophila (Foggie, 1951). However, due to morphological resemblance with Cytoecetes microti, an organism found in the polymorphonuclear cells of the vole Microtus pennsylvanicus (Tyzzer, 1938), it was later suggested to include the TBF agent in the genus Cytoecetes in the tribe Ehrlichia, as C. phagocytophila (Foggie, 1962).

In 1974, the organism was named Ehrlichia phagocytophila in Bergey's manual of determinative bacteriology (Philip, 1974). The discovery of E. chaffeensis in 1986, causative agent of human monocytic ehrlichiosis (Maeda et al., 1987; Anderson et al., 1991), and the agent of human granulocytic ehrlichiosis (HGE) in 1994 (Bakken et al., 1994; Chen et al., 1994), initiated new studies on the host associations, epidemiology and taxonomy of the granulocytic Ehrlichiae (Ogden et al., 1998). Genus Ehrlichia was divided into three genogroups, of which the granulocytic group contained E. phagocytophilum, E. equi [described in horses (Gribble, 
1969)] and the agent causing HGE. Later, a reclassification of the genus Ehrlichia was proposed, and based on phylogenetic studies, the granulocytic Ehrlichia group was renamed Anaplasma phagocytophilum (Dumler et al., 2001; Anonymous, 2002) (Table 1). However, it is still argued, whether the granulocytic Anaplasma should eventually be reclassified as distinct from the erythrocytic Anaplasma and returned to the previously published genus, Cytoecetes (Brouqui and Matsumoto, 2007).

\section{CLINICAL CHARACTERISTICS}

Natural infection with $A$. phagocytophilum has been reported, as already mentioned, in humans and a variety of domestic and wild animal species (Foley et al., 1999), whereas fatal cases have so far only been reported in sheep, cattle, horses, reindeer, roe deer, moose, dogs, and humans (Jenkins et al., 2001; Stuen, 2003; Franzén et al., 2007; Heine et al., 2007).

The main disease problems associated with TBF in ruminants are seen in young animals, and individuals purchased from tick-free areas and placed on tick-infested pastures for the first time. The most characteristic symptoms in domestic ruminants are high fever, anorexia, dullness, and sudden drop in milk yield (Tuomi, 1967a). However, the fever reaction may vary according to the age of the animals, the variant of $A$. phagocytophilum involved, the host species and immunological status of the host (Foggie, 1951; Tuomi, 1967b; Woldehiwet and Scott, 1993; Stuen et al., 1998). Abortion in ewes and reduced fertility in rams have also been reported. In addition, reduced weight gain in A. phagocytophilum infected bullocks and lambs have been observed (Taylor and Kenny, 1980; Stuen et al., 1992; Grøva et al., 2011).

A variable degree of clinical symptoms have also been detected in other mammals, such as fever, anorexia, depression, apathy, distal edema, reluctance to move, and petechial bleedings in horses, while the symptoms in dogs are characterized by fever, depression, lameness, and anorexia. In cats the predominant signs are anorexia, lethargy, hyperesthesia, conjunctivitis, myalgia, arthralgia, lameness, and incoordination (Egenvall et al., 1997; Bjöersdorff et al., 1999; Cohn, 2003; Franzén et al., 2005; Heikkilä et al., 2010).

In humans, clinical manifestations range from mild selflimiting febrile illness, to fatal infections. Commonly, patients express non-specific influenza-like symptoms with fever, headache, myalgias, and malaise (Bakken et al., 1994; Dumler, 1996). In addition, thrombocytopenia, leukopenia, anemia, and

Table 1 | Classification of genus Anaplasma, Ehrlichia, and Neorickettsia in the family Anaplasmataceae (modified after Dumler et al., 2001).

\begin{tabular}{llll}
\hline & \multicolumn{3}{c}{ Genus } \\
\cline { 2 - 4 } & Anaplasma & Ehrlichia & Neorickettsia \\
\hline Species & A. marginale & E. canis & N. risticii \\
& A. bovis & E. chaffeensis & N. sennetsu \\
& A. ovis & E. ewingii & \\
A. phagocytophilum & E. muris & \\
A. platys & E. ruminantium &
\end{tabular}

increased aspartate and alanine aminotransferase activity in sera are reported (Bakken and Dumler, 2008). However, most human infections probably result in minimal or no clinical manifestations. Reports from the US, indicate a hospitalization rate of $36 \%$, of which $7 \%$ need intensive care, while the case fatality rate is less than $1 \%$ (Dumler, 2012). A recent cohort study from China however, describes a mortality of $26.5 \%(22 / 83)$ in hospitalized patients (Li et al., 2011).

\section{DIAGNOSTIC AND LABORATORY METHODS CLINICAL SIGNS}

Clinical signs in ruminants may be sudden onset of high fever $\left(>41^{\circ} \mathrm{C}\right)$ and drop in milk yield, while symptoms in horses, dogs, and cats may be more vague and unspecific. In humans, a flulike symptom 2-3 weeks after tick exposure is an indicator of infection. However, laboratory confirmation is required to verify the diagnosis (Woldehiwet, 2010). To our knowledge, chronic infection has not yet been confirmed in any host, although persistent infections have been found to occur in several mammalian species.

\section{DIRECT IDENTIFICATION}

Light microscopy of blood smears taken in the initial fever period is normally sufficient to state the diagnosis. Stained with MayGrünwald Giemsa, the organisms appear as blue cytoplasmic inclusions in monocytes and granular leucocytes, especially neutrophils (Foggie, 1951). Electron microscopy may also confirm the diagnosis of acute Anaplasma infection in blood or organs. Single or multiple organisms are then identified in clearly defined cytoplasmic vacuoles (Tuomi and von Bonsdorff, 1966; Rikihisa, 1991). Immuno-histochemistry on tissue samples could also be performed to confirm the diagnosis (Lepidi et al., 2000).

\section{POLYMERASE CHAIN REACTION (PCR) AND CULTIVATION}

Several PCR techniques (conventional, nested, and real-time) for the identification of A. phagocytophilum infection in blood and tissue samples have been established primarily on basis of the $16 S$ rRNA, groEL, and p44 genes (Chen et al., 1994; Courtney et al., 2004; Alberti et al., 2005a). Multiple variants of A. phagocytophilum have been genetically characterized. Identification and stratification into phylogenetic subfamilies have been based on cell culturing, experimental infections, PCR and sequencing techniques (Dumler et al., 2007). Cultivation of A. phagocytophilum in cell cultures has been described for variants isolated from human, dog, horse, roe deer, and sheep (Goodman et al., 1996; Munderloh et al., 1999; Bjöersdorff et al., 2002; Woldehiwet et al., 2002; Silaghi et al., 2011c).

\section{SEROLOGY}

The presence of specific antibodies may support the diagnosis. A complement fixation test, counter-current immunoelectrophoresis test and an indirect immunofluorescent antibody (IFA) test can be used (Webster and Mitchell, 1988; Paxton and Scott, 1989). Several ELISA tests have also been developed (Ravyn et al., 1998; Magnarelli et al., 2001; Alleman et al., 2006; Woldehiwet and Yavari, 2012). A SNAP ${ }^{\circledR} 4 \mathrm{Dx}{ }^{\circledR}$ ELISA test is commercially available 
for rapid in-house identification of A. phagocytophilum antibodies in dog serum, but the kit has also been used successfully on horse and sheep sera (Granquist et al., 2010a; Hansen et al., 2010).

\section{PATHOLOGY}

An enlarged spleen, up to 4-5 times the normal size with subcapsular bleedings, has for decades been regarded as indicative of TBF in sheep (Gordon et al., 1932; Øverås et al., 1993). No other typical pathological changes have been described (Munro et al., 1982; Campbell et al., 1994; Lepidi et al., 2000). An enlarged spleen with subcapsular bleedings has also been observed in roe deer and reindeer (Stuen, 2003).

Relative sensitivity of the diagnostic tests used for laboratory diagnostic confirmation of A. phagocytophilum infection in humans is shown in Table 2.

\section{TREATMENT, PREVENTION, AND CONTROL}

The drug of choice is tetracycline (Woldehiwet and Scott, 1993; Dumler, 1996). Doxycyclin hyclate, given orally or intravenously, has been effective in treating clinical cases of human granulocytic anaplasmosis, and has led to clinical improvement in $24-48 \mathrm{~h}$. In human patients, treated with doxycycline for 7-10 days, infections have resolved completely and relapses have never been reported. In patients at risk of adverse drug reactions, rifampin therapy should be considered (Bakken and Dumler, 2006).

Current disease prevention strategies in domestic animals are based on the reduction of tick infestation by chemical acaricides, for instance at turn out on tick pasture. This is mostly done be dipping or with a variety of pour-on applications (Woldehiwet and Scott, 1993; Stuen, 2003). This treatment has to be repeated during the tick season. In the UK, long-acting tetracycline has also been used as a prophylactic measure given before animals are moved from tick-free environment into tick-infested pasture (Brodie et al., 1986; Woldehiwet, 2007). However, there is a growing concern about the environmental safety and human health, increasing costs of chemical control and the increasing resistance of ticks to pesticides (Samish et al., 2004).

Biological tick control is becoming an attractive approach to tick management. Biological control of tick infestations has been difficult because ticks have few natural enemies. Studies so far have concentrated of bacteria, entomopathogenic fungi, and nematodes (Samish et al., 2004). However, the main challenge is to create a sustainable biological control of ticks in the natural habitat.

Table 2 | Relative sensitivity of diagnostic tests for

A. phagocytophilum infection in humans (modified after Bakken and Dumler, 2006).

\begin{tabular}{lllll}
\hline $\begin{array}{l}\text { Duration of } \\
\text { illness (days) }\end{array}$ & $\begin{array}{l}\text { Blood smear } \\
\text { microscopy }\end{array}$ & $\begin{array}{l}\text { HL-60 cell } \\
\text { culture }\end{array}$ & PCR & IFAT \\
\hline $0-7$ & Medium & Medium & High & Low \\
$8-14$ & Low & Low & Low & Medium \\
$15-30$ & & & Low & High \\
$31-60$ & & & High \\
$>60$ & & & High
\end{tabular}

Vaccines against $A$. phagocytophilum are not yet available. Several vaccine candidates have been suggested, but the development of an effective vaccine has so far been difficult (Ijdo et al., 1998; Herron et al., 2000; Ge and Rikihisa, 2006). In order to develop a vaccine, one challenge is to choose antigens that are conserved among all variants of $A$. phagocytophilum.

Vaccines against ticks are also an alternative option. The development of vaccines that target both ticks and pathogen transmission may provide a mean of controlling tick-borne infections through immunization of the human and animal population at risk or by immunization of the mammalian reservoir to minimize pathogen transmission (de la Fuente and Kocan, 2006). Gut-, salivary-, or cement antigen vaccines (recombinant $\mathrm{Bm} / \mathrm{Ba} 86$, Bm91, and 64TRP) have been tested, and TickGUARDPLUS and Gavac (both recombinant Bm86) are examples of commercially available vaccines from the early 1990's (Willardsen, 2004; Labuda et al., 2006; de la Fuente et al., 2007; Canales et al., 2009). Other vaccines that inhibit subolesin expression are now being tested. These vaccines cause degeneration of gut, salivary gland, reproductive -and embryonic tissues and causes sterility in male ticks (de la Fuente et al., 2006a,b,c). Tick vaccines are feasible control methods, cost-effective and environmentally friendly compared to chemical control (de la Fuente and Kocan, 2006).

\section{TRANSMISSION AND COLONIZATION}

A. phagocytophilum has, as its name implies, a partiality to phagocytic cells and is one of very few bacteria known to survive and replicate within neutrophil granulocytes (Choi et al., 2005). During tick feeding, neutrophil-associated-inflammatoryresponses are modulated by various stimuli deployed by the tick sialome components (Beaufays et al., 2008; Guo et al., 2009; Heinze et al., 2012). Orchestration of vector-and bacterial interactions with the defensive mechanisms of the host animal seem to promote infection and transmission rather than controlling it, resulting in increased availability of infected cells in the circulating blood and at the site of tick bite (Choi et al., 2003, 2004; Granquist et al., 2010b; Chen et al., 2012). The low level of circulating organisms, detected between periods of bacteremia (Granquist et al., 2010c), may indicate temporary clearance of infected cells, possible margination of infected granulocytes to endothelial surface or immunologically modified intervals in generations of antigenically different organisms (Bakken et al., 1994; Beninati et al., 2006; Granquist et al., 2008). Because of the short-lived nature of circulating neutrophils, the role of these cells in establishing and maintaining infection has been questioned (Herron et al., 2005), however to date little is known about alternative cellular components involved in the invasion and colonization of A. phagocytophilum in the host organism (Granick et al., 2008).

A. phagocytophilum modulates the distribution of potential host cells and infected neutrophils, by inducing cytokine secretion and their receptors (Akkoyunlu et al., 2001; Scorpio et al., 2004) and promoting the loss of CD162 and CD62L (Choi et al., 2003). The bacterium further interacts with host cell ligands (Park et al., 2003; Granick et al., 2008), by surface exposed proteins known as adhesins (Yago et al., 2003; Ojogun et al., 2012) in order to facilitate internalization in the host cell (Wang et al., 2006). 
The translocation of bacteria to the inside of host cells is receptor mediated and depending on transglutaminase activity (reviewed by Rikihisa, 2003). However, host cell specific differences to receptors and their components as well as their importance in the infection process seem to exist, which may explain why certain bacterial strains, e.g., ruminant $A p$ Variant 1 strain, are refractory to culture in commercially available cell lines (like the HL-60 cell line) (Carlyon et al., 2003; Herron et al., 2005; Reneer et al., 2006, 2008; Massung et al., 2007). Previous reports have shown that various tissues and cells are susceptible to infection by A. phagocytophilum (Klein et al., 1997; Munderloh et al., 2004). It has been shown that intravascular myeloid cells (mature) have a higher infection rate than cells located in the bone marrow which may indicate that precursor stages of myeloid cells express ligands different from mature neutrophils, thus being more refractory to binding and internalization of the organism (Bayard-Mc Neeley et al., 2004). The coincidence that A. phagocytophilum uses CD162 when infecting neutrophils, led to the hypothesis that endothelium may have a function in the pathogenesis of $A$. phagocytophilum infection in vivo (Herron et al., 2005). However, a field study of skin biopsies in sheep observed A. phagocytophilum in inflammatory cell infiltrates comprised of PMNs and macrophages in the dermis and subcutis, and occasionally restricted to the mid- and peripheral parts of the blood vessel walls during tick attachment, thus questioning the role of endothelium in the pathogenesis of A. phagocytophilum infection in in the earliest phases of tick bite inoculation (Granquist et al., 2010b). Interestingly A. phagocytophilum has the ability to delay host cell apoptosis by activation of an anti-apoptosis cascade (Sarkar et al., 2012). This is critical for intracellular survival and reproduction of $A$. phagocytophilum in the normally short lived neutrophil granulocytes (Yoshiie et al., 2000; Lee and Goodman, 2006). Unlike other Gram-negative bacteria, A. phagocytophilum lacks lipopolysaccharides and peptidoglycans, but compensates for the loss of membrane integrity by incorporation of cholesterol which allows the escape of Nod Like Receptor and Toll Like Receptor activation pathways to successfully infect vertebrate immune cells (Lin and Rikihisa, 2003a,b; Hotopp et al., 2006; Xiong et al., 2007). However, recent studies in mice have surprisingly shown that alternative pathways involving the Nod 1 and 2 associated receptor interacting protein 2 may be important in control and clearance of $A$. phagocytophilum infection (Sukumaran et al., 2012).

\section{PERSISTENCE}

A. phagocytophilum has been found to persist in several mammalian hosts, such as sheep, dog, cattle, horses, and red deer (Foggie, 1951; Egenvall et al., 2000; Stuen, 2003; Larson et al., 2006; Franzén et al., 2009). However, this may vary according to the variants of the bacterium involved.

The ability of $A$. phagocytophilum to persist in immunecompetent hosts between seasons of tick activity is a complex and coordinated interaction that through evolutionary steps, have left the genomes of $A$. phagocytophilum and related organisms, heavily reduced to comprise essential genes allowing for nearly infinite numbers of recombined antigens and macromolecular exchange with its host cell (Rikihisa, 2011; Rejmanek et al., 2012).
Cyclic bacteremias display as periodic peaks containing genetically distinct variants of major surface proteins (MSP) (Granquist et al., 2008, 2010a). The capacity to generate novel antigens when other organisms are already present (superinfection) results in persistence and maintenance of the organism in natural transmission cycles and possibly allows spatial spread in nature (Barbet et al., 2003; Rodriguez et al., 2005; Futse et al., 2008; Ladbury et al., 2008; Stuen et al., 2009). Variants of MSPs such as MSp2 (or P44) contain epitopes recognized by antibodies appearing subsequently, but not prior to the respective peaks of rickettsemia in which they are expressed (Barbet et al., 2003; Granquist et al., 2010c), indicating a true process of antigenic variation influenced by the host immune response. Sequence variation may be achieved by segmental gene conversion of a single polycistronic expression site by insertion of total or partial pseudogene sequences (Barbet et al., 2000; Granquist et al., 2008) with the possible formation of mosaics or chimeras (Rejmanek et al., 2012). The large repertoire of donor sequences in A. phagocytophilum suggests that this bacterium may however only require simple gene conversion to evade host immune surveillance (Lin et al., 2003). On the other hand, the close proximity of the partial recombinase gene, $r e c A$, which is commonly involved in homologous recombinations supports the theory that recombination of pseudogenes by insertion in the expression site occurs (Barbet et al., 2003; Lin et al., 2003).

\section{VECTORS AND COMPETENT VECTORS OF $\boldsymbol{A}$. phagocytophilum}

A. phagocytophilum is transmitted by hard ticks of the I. persulcatus-complex. The main vector in Europe is I. ricinus (commonly known as sheep tick or castor been tick); in the Eastern US I. scapularis (deer tick or black-legged tick); in the Western US I. pacificus (Western black-legged tick), and in Asia I. persulcatus (taiga tick) (Woldehiwet, 2010). Vector competence has been proven for the American tick species I. scapularis (previously I. dammini), I. pacificus, and I. spinipalpis (Telford et al., 1996; Des Vignes et al., 1999; Zeidner et al., 2000; Teglas and Foley, 2006). Transovarial transmission has not been proven in Ixodes species, but in Dermacentor albipictus, which lifecycle involves a single host animal, representing a distinct ecological niche (Baldridge et al., 2009). As to current knowledge, a vertebrate reservoir host is necessary in nature for keeping the endemic cycle.

Prevalence data on molecular detection of A. phagocytophilum in questing ticks, show great variations within countries or continents where such studies have been performed. The infection rate in I. scapularis ranges from $<1 \%$ up to $50 \%$ and in $I$. pacificus from $<1 \%$ up to $\sim 10 \%$ in the US. Additionally, A. phagocytophilum has been detected in questing I. dentatus, Amblyomma americanum, Dermacentor variabilis, and D. occidentalis (Table 4; Goethert and Telford, 2003). In Asia, detection rates varied in I. persulcatus between $<1 \%$ up to $21.6 \%$ and questing $I$. ovatus, I. nipponensis, D. silvarum, Haemaphysalis megaspinosa, $H$. douglasii, $H$. longicornis, and $H$. japonica also contained DNA of A. phagocytophilum (Table 5). The greatest number of studies has been performed on questing I. ricinus ticks in Europe, where the prevalence rates vary between and also within countries. On average, the A. phagocytophilum-prevalence in $I$. ricinus in Europe 
ranges between $<1 \%$ and $\sim 20 \%$, in $I$. persulcatus-endemic areas in Eastern Europe between 1.7 and 16.7\%, and additionally DNA of A. phagocytophilum has been detected in questing D. reticulatus, $H$. concinna, and I. ventalloi (Table 3). Detailed information on worldwide prevalence rates of $A$. phagocytophilum in unfed ticks from the vegetation can be found in Tables 3-5.

Based on molecular detection in questing ticks, A. phagocytophilum seems to appear in all countries across Europe. In the US, the majority of studies have been performed in Eastern and Western (California) parts. From Northern US such data are lacking for several geographical regions, however serological evidence indicate exposure to A. phagocytophilum in large parts of the continent (Dugan et al., 2006; Bowman et al., 2009; Villeneuve et al., 2011). Two recent studies revealed the presence of A. phagocytophilum in questing ticks also in the Southern US (Florida and Georgia) (Clark, 2012; Roellig and Fang, 2012). Only few studies have been carried out in Asia, namely in Russia, China, Japan, and Korea (Table 5). It seems likely that other parts of Asia also belong to the endemic area of this pathogen.

Additionally to the ticks mentioned above, molecular detections have been reported from the following tick species (collected engorged from animals): I. hexagonus, I. trianguliceps, I. spinipalpis, I. ochotonae, and D. nutalli (Zeidner et al., 2000; Bown et al., 2003; Foley et al., 2011; Yaxue et al., 2011; Silaghi et al., 2012a). However, the vector competence of a lot of the tick species in which A. phagocytophilum has been detected as well as their contribution to the endemic cycle of $A$. phagocytophilum remain to be investigated.

The tick species I. ricinus, I. persulcatus, I. scapularis, and I. pacificus are found ubiquitously in their distribution range, have an open questing behavior and a broad host range, including many mammalian species (Sonenshine, 1993). These tick species may consequently also transmit the bacterium from animal reservoir hosts to humans. Aside from these aforementioned antropophilic and exophilic ticks, the involvement of nidicolous, and more host-specific endophilic ticks have been discussed in the context of so-called niche cycles, which may additionally keep the infection in nature. Examples for such proposed niche cycles involve cottontail rabbits (Sylvilagus spp.), I. dentatus and I. scapularis in the US (Goethert and Telford, 2003); field voles (Microtus agrestis), I. trianguliceps and I. ricinus in the UK (Bown et al., 2003); and hedgehogs (Erinaceus europaeus), I. hexagonus and I. ricinus in Europe (Silaghi et al., 2012a). The mentioned animals harbor two to three developmental stages of both endophilic and exophilic tick species and can thus transmit the agent from the animal host to humans via the anthropophilic tick species. Considering the large number of host specific and/or nidicolous ticks all around the world, it is likely that more potential niche cycles will be uncovered in the future (Foley et al., 2011).

Due to the comparatively low prevalence of $A$. phagocytophilum in I. pacificus in the Western US, I. spinipalpis has been suggested as a bridging vector for HGA (Zeidner et al., 2000). This nidiculous tick species infests, among others, Mexican woodrats (Neotoma mexicana) (in which A. phagocytophilum DNA has also been detected) and also occasionally bites humans and may thus transmit the agent from zooendemic cycles to humans.
Infection rates reported in many studies are higher in adult ticks than in nymphs. Due to the transstadial transmission, but lack of transovarial transmission, larvae are considered free of A. phagocytophilum. Adult ticks have had an additional blood meal in comparison to nymphs, and thus twice the chance of acquiring the infection. Variations in prevalence in questing ticks have also been observed with regard to the year of collection and in-between study areas and different geographic locations (Levin et al., 1999; Wicki et al., 2000; Hildebrandt et al., 2002; Cao et al., 2003; Holman et al., 2004; Ohashi et al., 2005; Grzeszczuk and Stanczak, 2006; Wielinga et al., 2006; Silaghi et al., 2008, 2012b; Schorn et al., 2011; Overzier et al., 2013b).

When looking at these variations, it has to be taken into account, that variations can be due to local variations, such as habitat structure or host availability, variation in methodology and sampling approach. Most studies shown in Tables 3-5 are single studies providing a spot prevalence, while studies including longitudinal data are scarce.

Variations in the prevalence of $A$. phagocytophilum in ticks may be attributed to several factors, such as the susceptibility of individual tick species, the susceptibility of certain tick populations, and the vector competence of tick species; the transmissibility of the A. phagocytophilum variant involved, the susceptibility of different host species, the susceptibility of individual hosts or host populations and the reservoir competence of the host. Especially the availability of different reservoir hosts and the adaptation strategy of A. phagocytophilum seem to be crucial factors in this variability. The availability of reservoir hosts depends on factors such as landscape structure and fragmentation (Medlock et al., 2013). In addition, effects exerted by changes in climate, demography, and agriculture may influence the tick distribution and density and their hosts.

\section{HOSTS AND RESERVOIRS}

Viable A. phagocytophilum organisms have been isolated from several hosts, such as cattle, sheep, goat, dog, horse, human, red deer (Cervus elaphus), roe deer (Caperolus capreolus), and white-tailed deer (WTD) (Odocoileus virginianus) (Foggie, 1951; Goodman et al., 1996; Munderloh et al., 1996; Woldehiwet et al., 2002; Massung et al., 2007; Stuen et al., 2010; Silaghi et al., 2011c). However, several prerequisites have to be fulfilled for a reservoir to be competent for a transstadially transmitted pathogen. A reservoir host must be fed on by an infected vector tick; it must take up a critical number of the infectious agent; it must allow the pathogen to multiply and survive for a period and it must allow the pathogen to find its way into other feeding ticks (Kahl et al., 2002). Several mammals may serve as hosts and reservoirs.

\section{WILD RUMINANTS}

In Europe, Asia, and America, A. phagocytophilum has been detected in local wild ruminant species (Tables 6-8). Wild ruminants such as WTD and roe deer are among the major feeding hosts for ticks in the Eastern US and Europe, respectively, and thus considered to contribute to a rapid increase in the population of ticks (Spielman et al., 1985; Vázquez et al., 2011; Medlock et al., 2013). WTD is considered one of the major reservoir hosts for an apathogenic variant (Ap-V1) of A. phagocytophilum in the Eastern 
Table 3 | Molecular prevalence studies of Anaplasma phagocytophilum in questing ticks in Europe*.




Table 3 | Continued

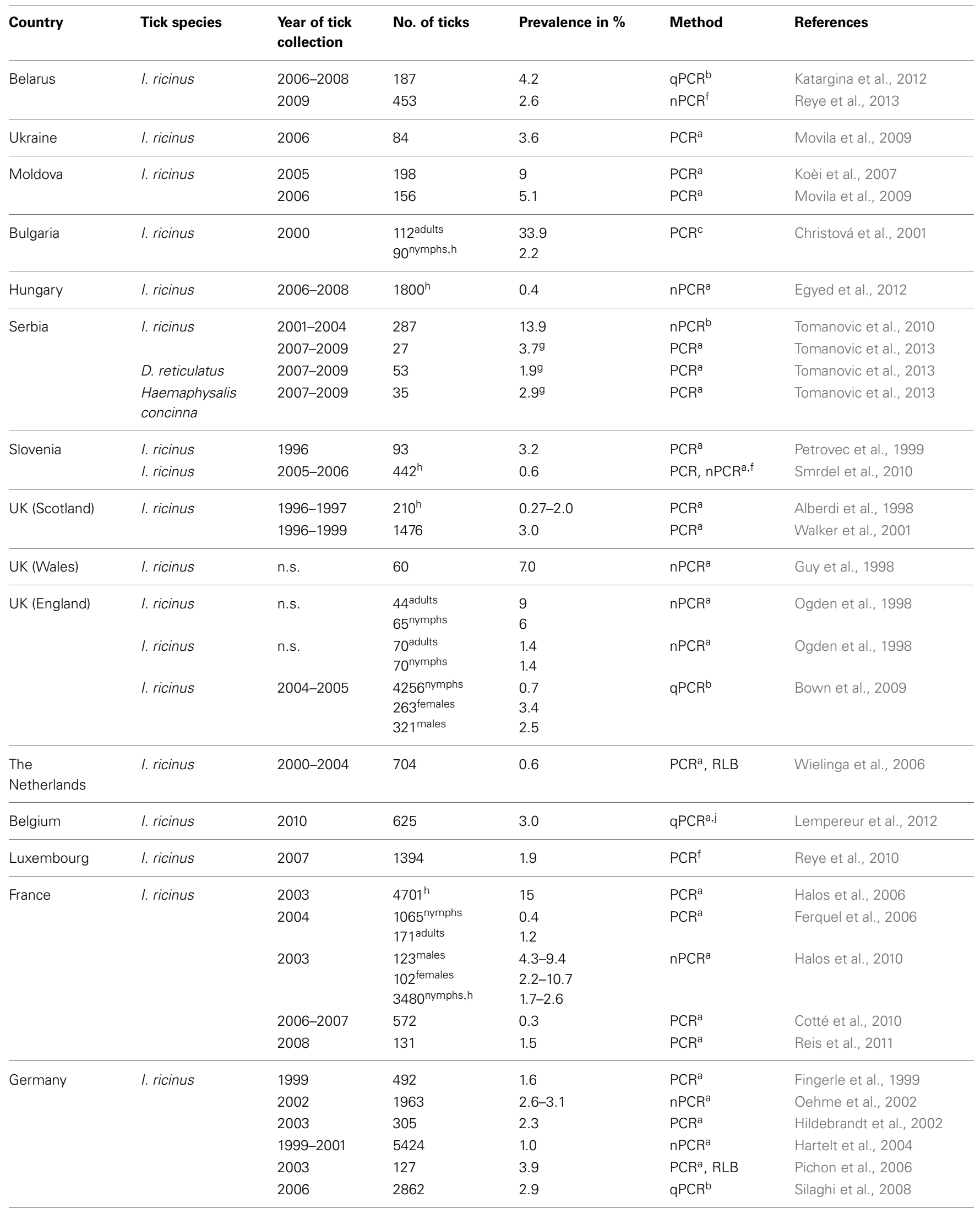


Table 3 | Continued

\begin{tabular}{|c|c|c|c|c|c|c|}
\hline Country & Tick species & $\begin{array}{l}\text { Year of tick } \\
\text { collection }\end{array}$ & No. of ticks & Prevalence in \% & Method & References \\
\hline & & 2006-2007 & 1000 & 5.4 & $\mathrm{PCR}^{\mathrm{a}}$ & Hildebrandt et al., 2010b \\
\hline & & 2005 & 1646 & 3.2 & $\mathrm{qPCR}^{\mathrm{b}}$ & Schicht et al., 2011 \\
\hline & & 2009-2010 & 5569 & $9.0^{9}$ & $q P C R^{b}$ & Schorn et al., 2011 \\
\hline & & n.s. & 542 & 4.1 & $\mathrm{PCR}^{\mathrm{b}}$ & $\begin{array}{l}\text { Richter and Matuschka, } \\
2012\end{array}$ \\
\hline & & $2009 i$ & 539 & 8.7 & & \\
\hline & & & 128 & 9.4 & & \\
\hline & & & 115 & 17.4 & $\mathrm{qPCR}^{\mathrm{b}}$ & Silaghi et al., 2012b \\
\hline & & 2011-2012 & 4064 & $5.3^{9}$ & $q P C R^{b}$ & Overzier et al., 2013b \\
\hline \multirow[t]{2}{*}{ Austria } & 1. ricinus & 2000-2001 & 235 & 5.1 & $\mathrm{PCR}^{\mathrm{a}}$ & Sixl et al., 2003 \\
\hline & & n.s. & 880 & 8.7 & $\mathrm{qPCR}^{f}$ & Polin et al., 2004 \\
\hline \multirow[t]{6}{*}{ Switzerland } & 1. ricinus & n.s. & 100 & 2 & $\mathrm{qPCR}^{\mathrm{a}}$ & Leutenegger et al., 1999 \\
\hline & & 1998 & 1667 & 1.3 & $\mathrm{qPCR}^{\mathrm{a}}$ & Pusterla et al., 1999 \\
\hline & & 1998 & 417 & 1.4 & $n P C R^{a}$ & Liz et al., 2000 \\
\hline & & 1999 & $6071^{\mathrm{h}}$ & 1.2 & $\mathrm{qPCR}^{\mathrm{a}}$ & Wicki et al., 2000 \\
\hline & & 2008 & 100 nymphs & 2 & $q P C R^{b}$ & Burri et al., 2011 \\
\hline & & 2009-2010 & 1476 & 1.5 & $\mathrm{qPCR}^{\mathrm{b}}$ & Lommano et al., 2012 \\
\hline \multirow[t]{6}{*}{ Italy } & 1. ricinus & n.s. & 86 & 24.4 & $\mathrm{PCR}^{\mathrm{a}}$ & Cinco et al., 1997 \\
\hline & & 2002 & 1014 & 9.9 & $\mathrm{nPCR}{ }^{\mathrm{a}}$ & Mantelli et al., 2006 \\
\hline & & 2000-2001 & 1931 & 4.4 & $\mathrm{PCR}^{\mathrm{a}}$ & Piccolin et al., 2006 \\
\hline & & 1998 & $55^{h}$ & 9 & PCR & Lillini et al., 2006 \\
\hline & & 2010 & 232 & 8.2 & $q P C R^{b}$ & Aureli et al., 2012 \\
\hline & & $2006-2008$ & 193 & 1.5 & $\mathrm{qPCR} \mathrm{R}^{\mathrm{b}}$ & Capelli et al., 2012 \\
\hline \multirow[t]{4}{*}{ Spain } & 1. ricinus & 2004 & $104^{\text {nymphs }}$ & 8.6 & $\mathrm{PCR}^{\mathrm{a}}$ & Portillo et al., 2005 \\
\hline & & & $54^{\text {adults }}$ & 3.7 & & \\
\hline & & 2005-2006 & 168 & 10.7 & $n P C R^{a}$ & Portillo et al., 2011 \\
\hline & & 2004 & n.s. & 20.5 & $\mathrm{PCR}^{\mathrm{a}}$ & Ruiz-Fons et al., 2012 \\
\hline \multirow[t]{4}{*}{ Portugal } & n.s. & $\begin{array}{l}\text { Archival } \\
\text { collection }\end{array}$ & 300 & 0.3 & $n P C R^{f}$ & de Carvalho et al., 2008 \\
\hline & 1. ricinus & 2003-2004 & $142^{h}$ & 4.0 & $\mathrm{PCR}^{\mathrm{a}, \mathrm{b}} \mathrm{PCR}^{\mathrm{b}}$ & Santos et al., 2004 \\
\hline & & n.s. & 101 & 6.9 & & $\begin{array}{l}\text { Richter and Matuschka, } \\
2012\end{array}$ \\
\hline & I. ventalloi & 2003-2004 & $93^{h}$ & 2.0 & $\mathrm{PCR}^{\mathrm{a}, \mathrm{b}}$ & Santos et al., 2004 \\
\hline Turkey & 1. ricinus & 2008 & 241 & $2.7-17.5^{i}$ & $n P C R^{a, b}$ & Sen et al., 2011 \\
\hline European and & & & & & & \\
\hline Asian part) & & & & & & \\
\hline
\end{tabular}

* This table does not claim completeness. It does not include studies with $0 \%$ prevalence and studies with mixed results for questing and engorged tick. nPCR, nested PCR; qPCR, real-time PCR; RLB, reverse line blot; n.s., not specified.

a 165 rRNA as gene target.

${ }^{b}$ Msp2 as gene target.

${ }^{c}$ AnkA as gene target.

${ }^{d}$ ApaG as gene target.

e Msp4 as gene target.

${ }^{f}$ GroEL as gene target.

${ }^{g}$ Total prevalence not specified in the paper, prevalence was calculated by the authors of the present manuscript.

h Study includes pools

iFrom different locations

jCommercial kit. 
Table 4 | Molecular prevalence studies of Anaplasma phagocytophilum in questing ticks in the USA*.

\begin{tabular}{|c|c|c|c|c|c|c|}
\hline State & Tick species & Year of tick collection & $\begin{array}{l}\text { No. of } \\
\text { ticks }\end{array}$ & Prevalence in \% & Method & References \\
\hline New Hampshire & Ixodes scapularis & 2007 & 509 & $0.2^{\mathrm{e}}$ & PCR & Walk et al., 2009 \\
\hline Rhode Island & I. scapularis & 1996-1999 & 538 & 22.9 & $n P C R^{a}$ & Massung et al., 2002 \\
\hline \multirow[t]{3}{*}{ Connecticut } & I. scapularis & 1994 & 120 & 50.0 & $\mathrm{PCR}^{\mathrm{a}}$ & Magnarelli et al., 1995 \\
\hline & & 1996-1997 & 1115 & $1.2-19.0^{\mathrm{e}}$ & $\mathrm{PCR}^{\mathrm{a}}$ & Levin et al., 1999 \\
\hline & & 1996-1999 & 375 & 13.3 & $\mathrm{nPCR}{ }^{a}$ & Massung et al., 2002 \\
\hline \multirow[t]{3}{*}{ New York } & I. scapularis & $2003-2004$ & $25^{\text {females }}$ & 40.0 & $\mathrm{nPCR}^{\mathrm{c}}$ & Moreno et al., 2006 \\
\hline & & & $32^{\text {males }}$ & 50.0 & & \\
\hline & & & $62^{\text {nymphs }}$ & 27.0 & & \\
\hline New Jersey & I. scapularis & 2001 & 107 & 1.9 & $\mathrm{PCR}^{\mathrm{a}}$ & Adelson et al., 2004 \\
\hline Pennsylvania & I. scapularis & 2005 & 94 & 1.1 & $\mathrm{PCR}^{\mathrm{a}}$ & Steiner et al., 2008 \\
\hline \multirow[t]{3}{*}{ Wisconsin } & I. scapularis & 1998 & 636 & 3.8 & $\mathrm{PCR}^{\mathrm{a}}$ & Shukla et al., 2003 \\
\hline & & 2006 & 100 & 14 & $\mathrm{nPCR}{ }^{a}$ & Steiner et al., 2008 \\
\hline & & 2008 & 201 & 12.0 & $\mathrm{qPCR}{ }^{\mathrm{b}}$ & Lovrich et al., 2011 \\
\hline \multirow[t]{2}{*}{ Indiana } & I. scapularis & 2003 & 68 & 11.8 & $\mathrm{nPCR}{ }^{a}$ & Steiner et al., 2006 \\
\hline & & 2004 & 100 & 5 & $\mathrm{nPCR}{ }^{\mathrm{a}}$ & Steiner et al., 2008 \\
\hline Maine & I. scapularis & 2003 & 100 & 16 & $n P C R^{a}$ & Steiner et al., 2008 \\
\hline Maryland & 1. scapularis & 2003 & 348 & 0.3 & $\mathrm{PCR}^{\mathrm{a}}$ & Swanson and Norris, 2007 \\
\hline \multirow[t]{2}{*}{ Florida } & I. scapularis & 2004-2005 & 236 & 1.3 & $P R^{b}$ & Clark, 2012 \\
\hline & Amblyomma americanum & 2004-2005 & 223 & 2.7 & $\mathrm{PCR}^{\mathrm{b}}$ & Clark, 2012 \\
\hline Georgia & I. scapularis & 2004-2005 & 808 & 20.0 & $\mathrm{nPCR}{ }^{\mathrm{d}}$ & Roellig and Fang, 2012 \\
\hline \multirow[t]{13}{*}{ California } & Ixodes pacificus & 1995-1996 & $1112^{\text {adults }, f}$ & 0.8 & $\mathrm{nPCR}{ }^{a}$ & Barlough et al., 1997a \\
\hline & & & $47^{\text {nymphs,f }}$ & 2.1 & & \\
\hline & & 1997 & 84 & $1.2^{\mathrm{e}}$ & $\mathrm{PCR}^{\mathrm{C}}$ & Nicholson et al., 1999 \\
\hline & & 1996-1997 & $401^{f}$ & 2.0 & $\mathrm{nPCR}{ }^{\mathrm{a}}$ & Kramer et al., 1999 \\
\hline & & 1998 & $465^{\text {adults }}$ & 0 & $\mathrm{PCR}^{\mathrm{a}}$ & Lane et al., 2001 \\
\hline & & & $202^{\text {nymphs }}$ & 9.9 & & \\
\hline & & 2000-2001 & 776 & 6.2 & $\mathrm{PCR}^{\mathrm{b}}$ & Holden et al., 2003 \\
\hline & & 2002 & 234 & 3.4 & $\mathrm{nPCR}{ }^{a}$ & Lane et al., 2004 \\
\hline & & 2000-2001 & 168 & 3.0 & $\mathrm{PCR}^{\mathrm{b}}$ & Holden et al., 2006 \\
\hline & & $2005-2007$ & 138 & $2.2^{\mathrm{e}}$ & $q P C R^{b}$ & Rejmanek et al., 2011 \\
\hline & Dermacentor variabilis & 2000-2001 & 58 & 8.6 & $\mathrm{PCR}^{\mathrm{b}}$ & Holden et al., 2003 \\
\hline & D. occidentalis & 2000-2001 & 353 & 1.1 & $\mathrm{PCR}^{\mathrm{b}}$ & Holden et al., 2003 \\
\hline & & 2003-2005; 2009-2010 & 513 & 0.2 & $n P C R^{a}$ & Lane et al., 2010 \\
\hline
\end{tabular}

*This table does not claim completeness. It does not include studies with $0 \%$ prevalence and studies with mixed results for questing and engorged ticks.

nPCR, nested PCR; qPCR, real-time PCR; n.s., not specified.

a $16 S$ rRNA as gene target.

${ }^{b}$ Msp2 as gene target.

${ }^{c}$ GroESL as gene target.

aAnkA as gene target.

${ }^{e}$ Calculated by the authors of the present manuscript.

${ }^{f}$ Study includes pools.

US (Massung et al., 2005). Several genetic variants of A. phagocytophilum have been found in roe deer in Europe and there seem to be both potentially pathogenic and apathogenic variants occurring in roe deer (Silaghi et al., 2011b; Overzier et al., 2013a). A high roe deer density is associated with a high tick density (Jensen et al., 2000; Carpi et al., 2008; Rizzoli et al., 2009) and both presence and high density of roe deer seems to have a positive effect on the A. phagocytophilum prevalence (Rosef et al., 2009). Similarly, the density of WTD influences the density of I. scapularis ticks in the north-eastern US (Rand et al., 2003). For example, the elimination of WTD from certain areas lead to a drastic reduction of the occurrence of I. scapularis (Wilson et al., 1988). In a later study, however, there was no direct effect of a deer culling program on the occurrence of I. scapularis developmental stages (Jordan et al., 2007).

In the US, WTD has prevalence rates of A. phagocytophilum of up to $46.6 \%$ (Table 6), while detection of A. phagocytophilum in wild ruminants other than WTD are scarce so far. In Europe, roe deer show prevalence rates reaching up to $98.9 \%$ (Overzier et al., 2013a). Other deer species seem to contribute to the endemic 
Table 5 | Molecular prevalence studies of Anaplasma phagocytophilum in questing ticks in Asia*.

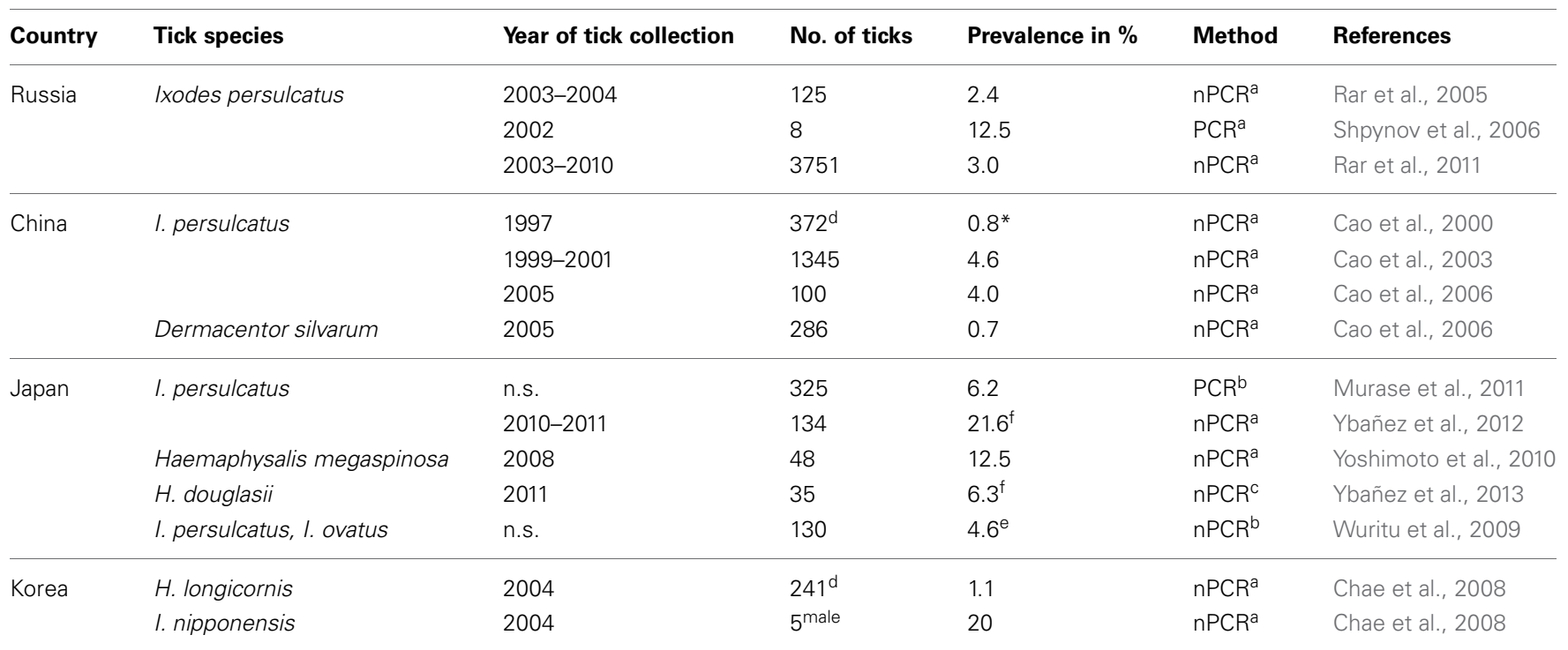

*This table does not claim completeness. It does not include studies with $0 \%$ prevalence and studies with mixed results for questing and engorged tick.

nPCR, nested PCR; n.s., not specified.

a $16 S$ rRNA gene as target.

${ }^{b}$ Msp2 gene as target.

${ }^{c}$ GroEl gene as target.

'Study includes pools.

el. persulcatus and I. ovatus.

${ }^{f}$ Total prevalence not specified in the paper, prevalence was calculated by the authors of the present manuscript.

cycles in Europe, and may also constitute efficient reservoir hosts, as the pathogen has been detected in red deer with up to $87 \%$ prevalence, in fallow deer (Dama dama) with up to $72 \%$, and in sika deer (Cervus nippon) with up to 50\% (Table 7). A. phagocytophilum has also been identified in deer species in Asia, namely sika deer and water deer (Hydropotes inermis) with prevalence rates of up to $46 \%$ and of $63.6 \%$, respectively (Jilintai et al., 2009; Kang et al., 2011; Table 8). However, the studies that have been conducted in Asia on wild ruminants are too few as to draw any definite conclusion on the distribution of A. phagocytophilum.

\section{SMALL MAMMALS}

The second large group of animals that A. phagocytophilum is found in endemic countries are in small mammals such as rodents and insectivores. These animals also are major feeding hosts for ticks, especially for the developmental stages (Kiffner et al., 2011). DNA of A. phagocytophilum was found in different mouse, vole, other rodent and insectivore species in the US, Europe, and Asia (Tables 6-8).

\section{Rodents}

In Europe, yellow-necked mice (Apodemus flavicollis) were infected with ranges from $<1$ to $15 \%$, wood mice (Apodemus sylvaticus) from $<1$ to $11 \%$ and bank voles (Myodes glareolus) from 5 to $19.2 \%$. In mouse species, detection with higher prevalence rates represents only single studies, whereas detection in bank voles seemed higher and more consistent. This was also the case for other vole species in Europe (Table 6). In the UK, the field vole has been discussed as a potential small mammal reservoir (Bown et al., 2003). However, in several studies on rodents in Europe, no DNA of A. phagocytophilum has been detected or at such low prevalence rates, that a reservoir role of this group of animals in Europe remains unclear (Barandika et al., 2007; Silaghi et al., 2012b; Table 6).

On the contrary, in the Eastern US, the white-footed mouse (Peromyscus leucopus) is considered one of the major reservoir hosts for the human pathogenic variant (Ap-ha) (Massung et al., 2003). P. leucopus is found as the predominant small mammal in forested habitats throughout the Eastern and Central US and it is one of the major hosts for the larval stages of I. scapularis (Sonenshine, 1993). The white-footed mouse has reservoir competence for the AP-ha variant, but reservoir competence could not be shown for the apathogenic Ap-V1 variant (Massung et al., 2003), as opposed to the aforementioned WTD as a major reservoir hosts for Ap-V1 (Massung et al., 2005). Different lengths of infections with the two strains have also been shown in an experimental WTD study: Ap-V1 from tick cells resulted in lasting parasitemia, whereas infection with Ap-ha was short-lived (Reichard et al., 2009). By contrast, both Ap-V1 and Ap-ha were infectious for goats and goats are reservoir competent to Ap-V1 (Massung et al., 2006).

Ap-V1 was isolated from goats and I. scapularis and propagated in the ISE6 tick cell line, but it could not be cultivated in the human HL-60 cell line. This stands in contrast to A. phagocytophilum strains which have been isolated from human cases in the US, which readily grow in HL-60 cell lines (Horowitz et al., 
Table 6 | DNA-Detection of Anaplasma phagocytophilum in blood/spleen in vertebrate hosts in the Americas*.

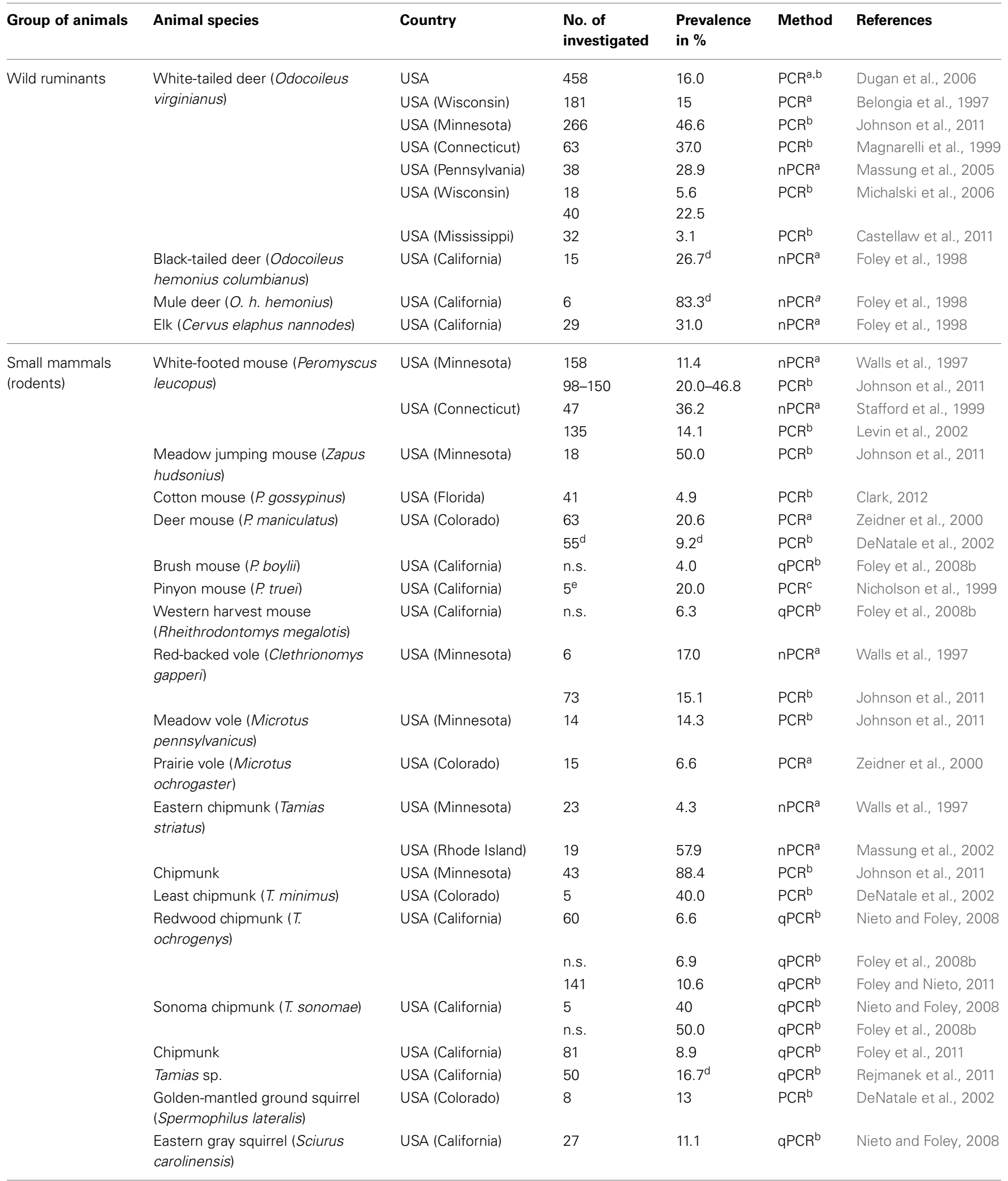









\begin{tabular}{|c|c|c|c|c|c|c|}
\hline Group of animals & Animal species & Country & $\begin{array}{l}\text { No. of } \\
\text { investigated }\end{array}$ & $\begin{array}{l}\text { Prevalence } \\
\text { in } \%\end{array}$ & Method & References \\
\hline & & USA (California) & 97 & 7 & $\mathrm{qPCR}^{\mathrm{b}}$ & Drazenovich et al., 2006 \\
\hline & & & 184 & 7.6 & $\mathrm{qPCR}^{\mathrm{b}}$ & Henn et al., 2007 \\
\hline & & Brazil & 253 & 7.1 & $\mathrm{qPCR}^{\mathrm{b}}$ & Santos et al., 2011 \\
\hline & Horse & Guatemala & 74 & 13 & $n P C R^{a}$ & Teglas et al., 2005 \\
\hline & Cattle & Guatemala & 48 & 51 & $\mathrm{nPCR}{ }^{\mathrm{a}}$ & Teglas et al., 2005 \\
\hline
\end{tabular}

*This table does not claim completeness. It does not include studies with $0 \%$ prevalence and case reports.

nPCR, nested PCR; qPCR, real-time PCR; n.s., not specified.

a 165 rRNA as gene target.

${ }^{b}$ Msp2 as gene target.

${ }^{c}$ GroEL as gene target.

${ }^{d}$ Total prevalence/number not specified in the paper, prevalence/number was calculated by the authors of the present manuscript.

e Seropositive for Anaplasma phagocytophilum antibodies.

${ }^{f}$ Includes recaptures.

g Partially with symptoms.

1998; Massung et al., 2007), suggesting differing host specificity for these two strain types.

Apart from the white-footed mouse, A. phagocytophilum DNA has been detected in several rodent species such as voles and chipmunks in the Eastern US, cotton mice and cotton rats in Florida and several mouse-, chipmunk-, and squirrel-species as well as the dusky-footed woodrat (Neotoma fuscipes) in the Western US (Table 7). Prevalence ranges from 1.8 to $88.4 \%$. The gray squirrel (Sciurus carolinensis) has also been found to be reservoir competent (Levin et al., 2002) and the redwood chipmunk (Tamias ochrogenys) and sciurid rodents are discussed as important reservoir hosts for A. phagocytophilum in the Western US (Nieto et al., 2010; Foley and Nieto, 2011). Similarly to other small mammals that have been suggested to maintain niche cycles, the redwood chipmunk hosts both antropophilic (I. pacificus) and nidicolous (I. angustus) ticks (Foley and Nieto, 2011).

In Asia, comparatively high prevalence rates in small mammals also seem to indicate a reservoir function of this group of mammals (Table 8). For example, in China, wood mice showed prevalence rates up to $10.0 \%$ (Zhan et al., 2008), Korean field mice (A. peninsulae) up to $25 \%$ (Zhan et al., 2010) and blackstriped field mice (A. agrarius) up to $20.8 \%$ (Cao et al., 2006). In Korea, prevalence rates in the black-striped field mouse was also up to $23.6 \%$ (Kim et al., 2006) and therefore, A. agrarius has been discussed as one of the major reservoir host in Asian countries. In the Asian part of Turkey, however, all captured rodents were serologically negative for A. phagocytophilum (Güner et al., 2005).

Additionally to mice, voles, chipmunks, and squirrels, DNA of A. phagocytophilum has also been detected in rats on all three continents, in hamsters (China) and in a porcupine (Italy) (Tables 6-8).

\section{Insectivores}

There are very few published studies on the role of insectivores in the life cycle of $A$. phagocytophilum. The common shrew (Sorex araneus) has been discussed as a reservoir host for $A$. phagocytophilum in the UK (Bown et al., 2011). In that study, prevalence reached $18.7 \%$. Other insectivores which have been investigated in Europe were the greater white-toothed shrew (Crocidura russula) and the European hedgehog (Table 6). DNA of A. phagocytophilum has also been detected in short-tailed shrews (Blarina brevicauda) with $17.2 \%$ prevalence in the US and in Asia in whitetoothed shrews with $63.6 \%$ prevalence (Tables 6, 8). Detection rates of $A$. phagocytophilum in insectivores were generally high, with average prevalence rates around $20 \%$, reaching over $80 \%$. However, the role of insectivores in the life cycle of $A$. phagocytophilum needs further investigation.

\section{OTHER ANIMAL SPECIES}

Apart from wild ruminants, rodents and insectivores, there are several other vertebrate species in which DNA from A. phagocytophilum has been isolated. Whether these contribute to the endemic cycle of A. phagocytophilum is currently not clear. Amongst these animals are mammals such as wild boars, foxes, and bears, but also birds and reptiles (Tables 6-8). The prevalence rates in these animal species seem similar to the potential reservoir hosts discussed above, but studies have been very few so a final conclusion is not yet possible. In the US, raccoons (Procyon lotor) have been found to be reservoir competent for A. phagocytophilum (Levin et al., 2002; Yabsley et al., 2008), while wild boar (Sus scrofa) has recently been discussed as a host for human pathogenic variants of $A$. phagocytophilum in Europe (Michalik et al., 2012).

The questions which remain open are whether many different animal species get infected only temporarily with potentially nonspecies specific strains of $A$. phaogcytophilum and constitute deadend hosts such as human beings, whether they develop clinical signs of disease or if they contribute in any way to the endemic cycle.

\section{DOMESTIC ANIMALS}

Dogs in Europe were positive for DNA of A. phagocytophilum at about $1-6 \%$ prevalence, regardless whether they show symptoms of canine granulocytic anaplasmosis or not. By comparison, the 
Table 7 | Detection of DNA of Anaplasma phagocytophilum in blood or tissue (majority spleen) of vertebrate hosts in Europe*.




Table 7 | Continued

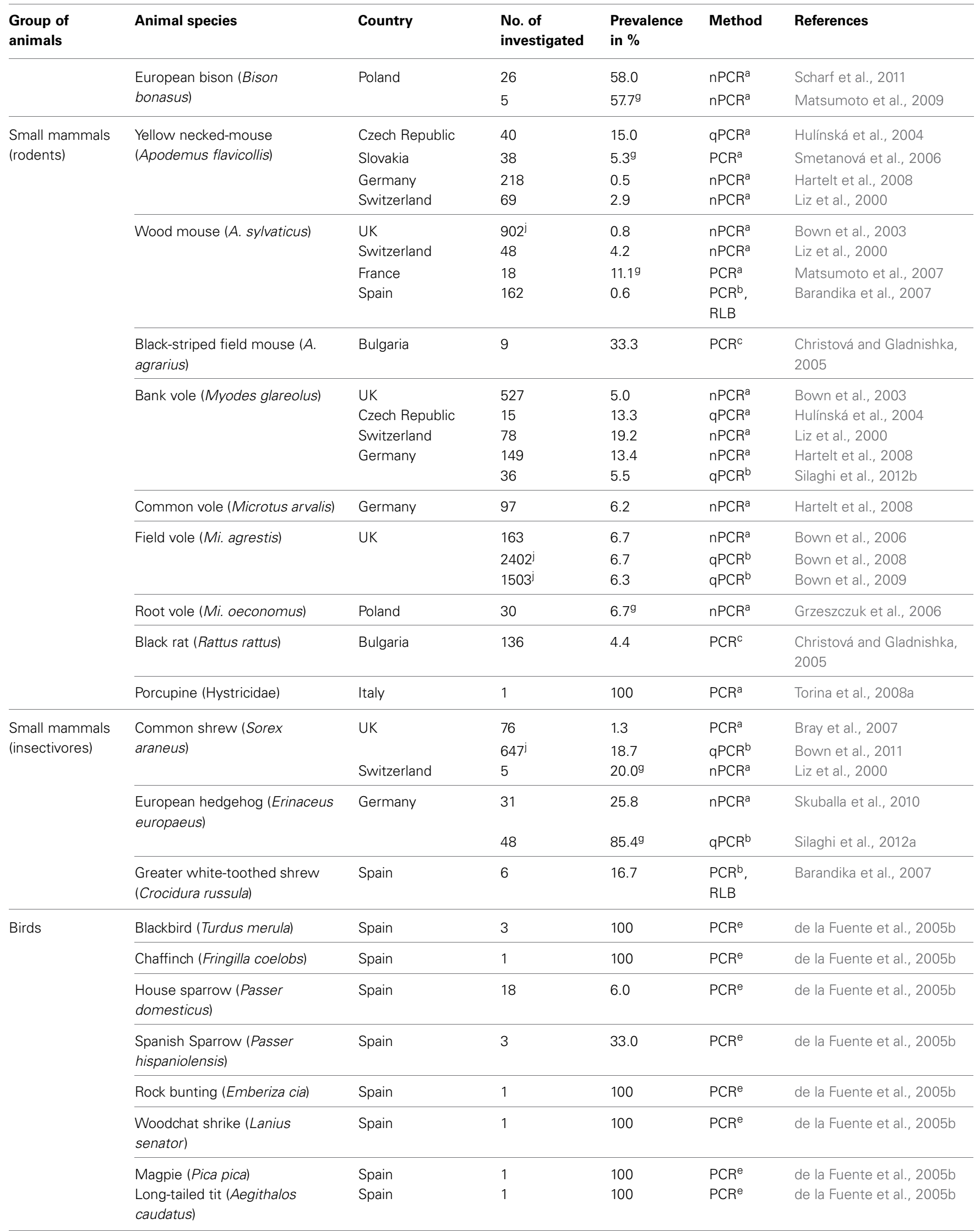




\section{Table 7 | Continued}

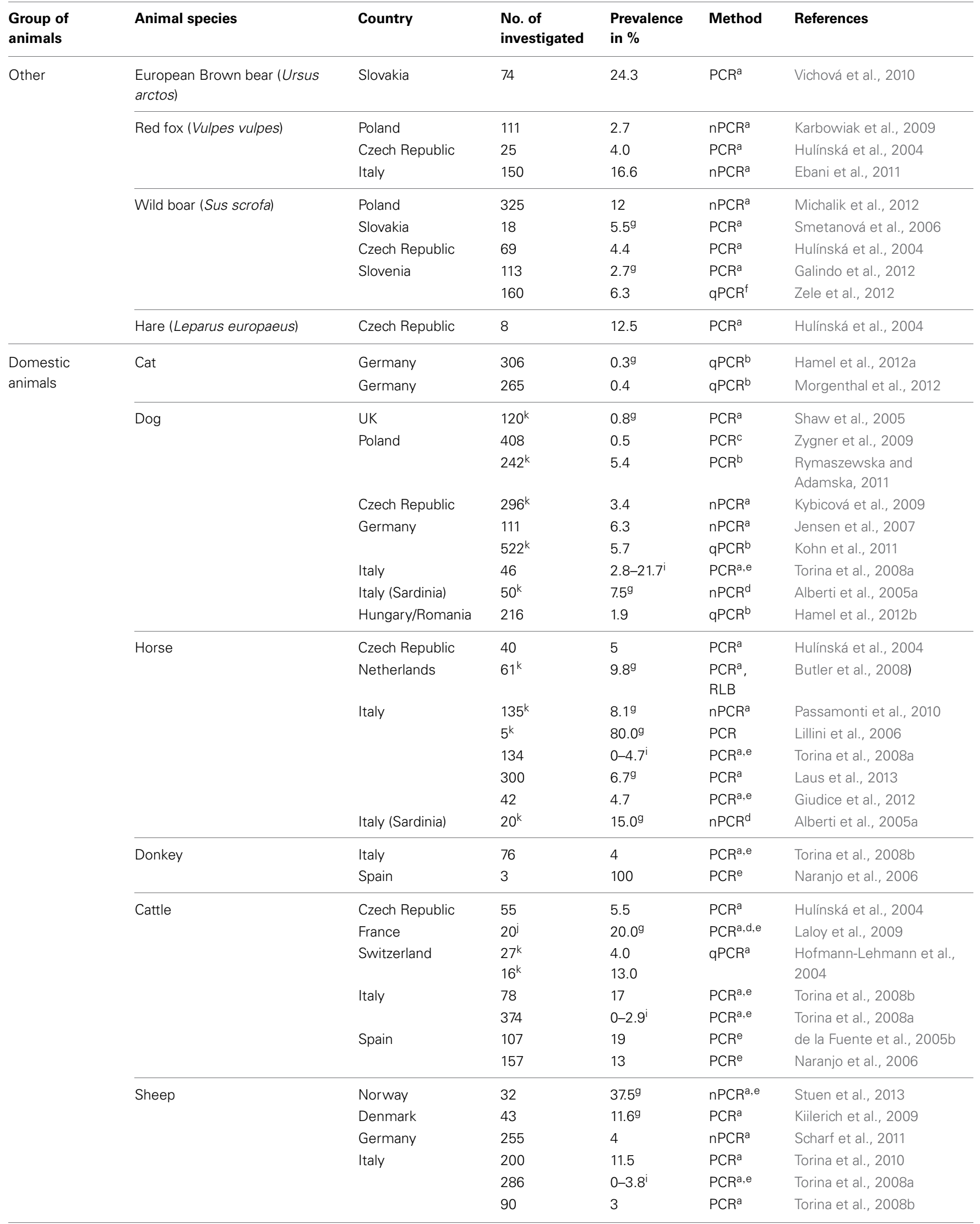


Table 7 | Continued

\begin{tabular}{|c|c|c|c|c|c|c|}
\hline $\begin{array}{l}\text { Group of } \\
\text { animals }\end{array}$ & Animal species & Country & $\begin{array}{l}\text { No. of } \\
\text { investigated }\end{array}$ & $\begin{array}{l}\text { Prevalence } \\
\text { in } \%\end{array}$ & Method & References \\
\hline & Sheep, goats & $\begin{array}{l}\text { Slovakia, Czech } \\
\text { Republic }\end{array}$ & 323 & $2.8^{h}$ & $P C R^{e}$ & Derdáková et al., 2011 \\
\hline & \multirow[t]{2}{*}{ Goats } & Switzerland & 72 & $5.6^{9}$ & $\mathrm{qPCR}^{\mathrm{b}}$ & Silaghi et al., 2011e \\
\hline & & Italy & 134 & $0-3.5^{i}$ & $\mathrm{PCR}^{\mathrm{a}, \mathrm{e}}$ & Torina et al., 2008a \\
\hline
\end{tabular}

\footnotetext{
${ }^{*}$ This table does not claim completeness. It does not include studies with $0 \%$ prevalence and case reports.

nPCR, nested PCR; qPCR, real-time PCR; RLB, reverse line blot, SB, Southern Blot.

a $16 S$ rRNA as gene target.

${ }^{b}$ Msp2 as gene target.

${ }^{c}$ AnkA as gene target.

${ }^{d}$ GroEL as gene target.

e Msp4 as gene target.

${ }^{f}$ Commercial kit.

${ }^{g}$ Total prevalence not specified in the paper, prevalence was calculated by the authors of the present manuscript.

' Sheep only.

${ }^{i}$ Range represents confidence interval.

iIndividuals sampled several times.

k Partially with symptoms.
}

prevalence rates in cats were much lower, with $<0.5 \%$. In horses, prevalence was higher ranging up to $80 \%$, however, several of the studies investigated horses with symptoms of equine granulocytic anaplasmosis. Without any clinical signs, the prevalence in horses was less than $6.7 \%$ (Tables 6-8). Furthermore, several case reports and case series have been published on domestic animals in North America (e.g., Cockwill et al., 2009; Granick et al., 2009; Uehlinger et al., 2011), and serological studies have shown a wide evidence of dogs, cats, and horses being in contact with A. phagocytophilum in USA, Canada, and Asia (e.g., Magnarelli et al., 2001; Billeter et al., 2007; Bowman et al., 2009; Villeneuve et al., 2011; Bell et al., 2012; Ybañez et al., 2012). Additionally, serological and molecular evidence have been provided from North Africa (which also is an endemic area for I. ricinus) that horses and dogs become infected with A. phagocytophilum (M'Ghirbi et al., 2009, 2012). This important finding broadens the known geographic range of $A$. phagocytophilum to Africa as another continent.

The role of dogs as reservoir hosts has been discussed (Schorn et al., 2011). Furthermore, a report of granulocytic anaplasmosis has been described in another member of the canine family, a captive timber wolf (Canis lupus) (Leschnik et al., 2012). The question remains open whether dogs can contribute to the natural cycle of $A$. phagocytophilum: Is the infection persistent enough for subsequent ticks to become infected, and do dogs host enough nymphal stages of ticks to contribute to the spread? Animals which host mainly adult ticks cannot effectively contribute to the life cycle of $A$. phagocytophilum, as transovarial infection does not seem to occur.

\section{DOMESTIC RUMINANTS}

Infection with $A$. phagocytophilum has also been detected in several domestic ruminant species such as sheep, goats, cattle, and yaks (Tables 6-8). In Europe, domestic ruminants have been found infected with DNA with rates of up to $20 \%$ (cattle), $37 \%$ (sheep), and 5.6\% (goats) (Table 6). However, larger scale molecular studies on domestic ruminants in Northern America are lacking, but cases of granulocytic anaplasmosis have been described in llama (Lama glama) and alpaca (Vicugna pacos) in California and Massachusetts, respectively (Barlough et al., 1997a,b; Lascola et al., 2009). Furthermore, serological evidence has been provided for A. phagocytophilum antibodies in cattle in Connecticut (Magnarelli et al., 2002).

\section{SPREAD OF INFECTION}

A. phagocytophilum may be spread between different geographic regions by both infected ticks and infected hosts. Expansion of existing endemic areas or to new geographic regions occurs when populations of competent vectors and reservoirs or the abundance of susceptible hosts increase both in total number and in geographic range.

Roe deer carry large number of ticks and moves over long distances (Vor et al., 2010) and may therefore add to the spread of the pathogen itself as well as by moving infected ticks to other areas (Overzier et al., 2013a). Factors contributing to a wider occurrence of suitable hosts such as WTD, white-footed mice, roe deer, field mice etc. may be landscape changes leading to an expansion in the distribution range as well as in the density of those hosts.

Landscape changes such as reforestation may also lead to an expansion of the anthropophilic ticks which are spread also when their primary feeding hosts expand (Sonenshine, 1993).

The increase and spread of I. scapularis in the Eastern US has lead to an increase in Lyme Borreliosis cases (Sonenshine, 1993) and may similarly contribute to the expansion of $A$. phagocytophilum. In Europe, the increasing geographic range of $I$. ricinus as well as the expansion to higher altitudes has recently been discussed by several authors (Materna et al., 2005; Jore et al., 2011; Jaenson et al., 2012; Medlock et al., 2013). 
Table 8 | Detection of DNA of Anaplasma phagocytophilum in spleen/blood of vertebrate hosts in Asia and Africa*.

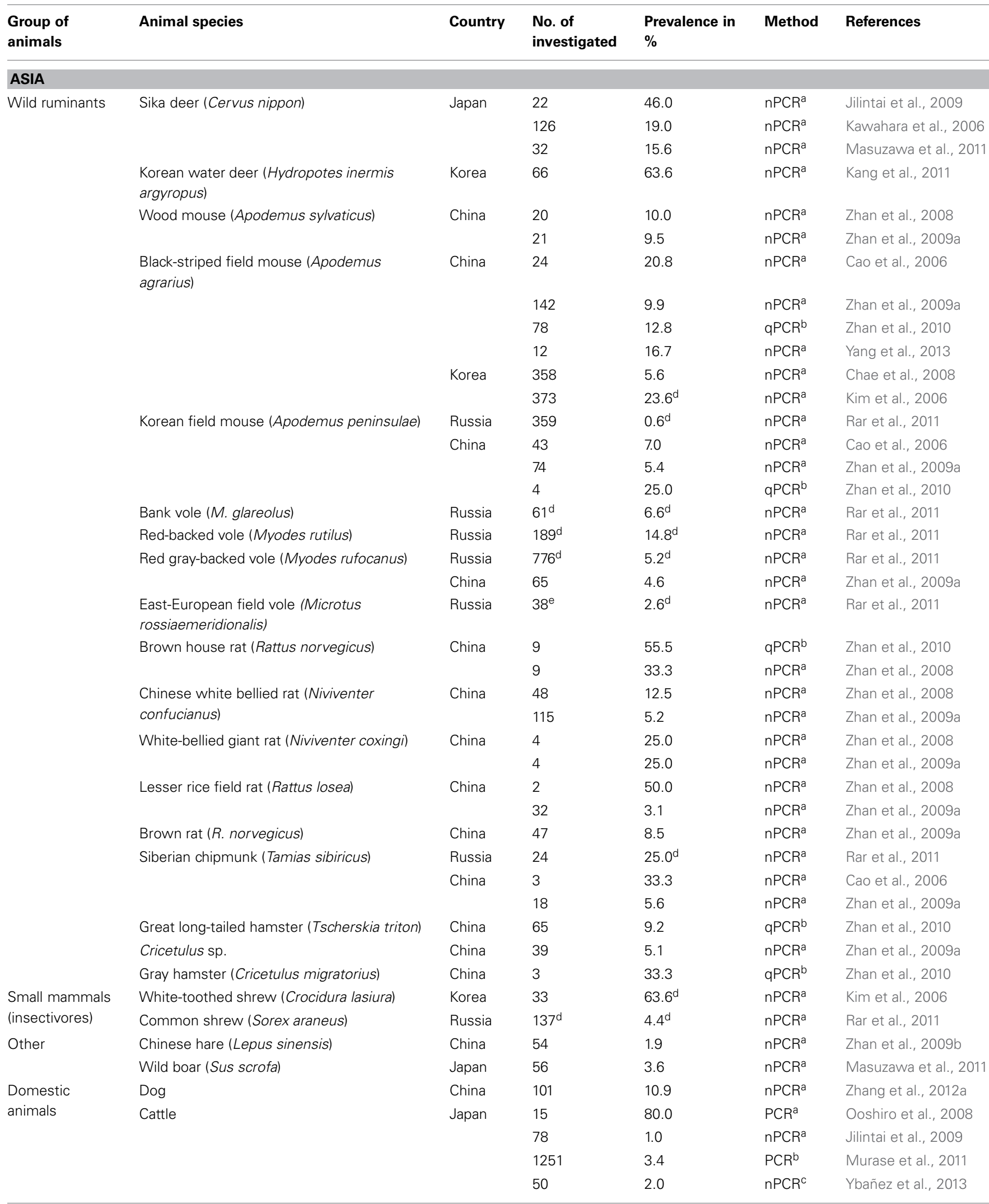


Table 8 | Continued

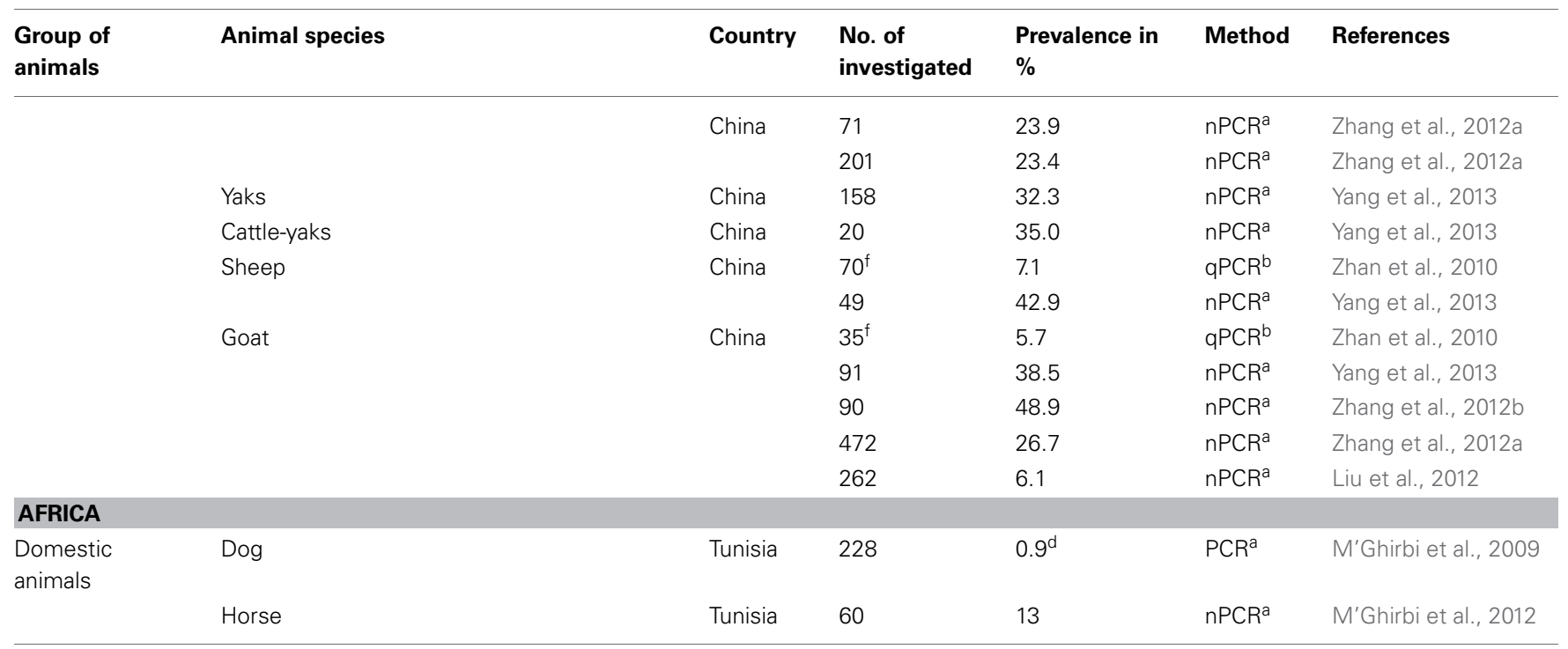

*This table does not claim completeness. It does not include studies with $0 \%$ prevalence.

nPCR, nested PCR; qPCR, real-time PCR.

a $16 S$ rRNA gene as target.

${ }^{b}$ Msp2 gene as target.

${ }^{c}$ GroEL gene as target.

d Total prevalence not specified in the paper, prevalence was calculated by the authors of the present manuscript

e Microtus spp.

${ }^{f}$ Partially with symptoms.

Domestic animals including pet animals such as the dog and farm animals such as sheep and cattle may be transported to other areas, in-between countries, even continents, and can thus also add to the spread of infection. Ticks may be spread by birds over long distances and with them A. phagocytophilum-infected ticks. Studies from Europe indicate that migrating birds may be important in the dispersal of $A$. phagocytophilum infected I. ricinus (Alekseev et al., 2001b; Bjöersdorff et al., 2001). However, A. phagocytophium DNA has sometimes been detected in ticks collected from birds at low prevalence, and it was questioned by some authors whether birds may really be involved in the spreading of the pathogen whereas other authors discussed their possible involvement (Daniels et al., 2002; Ogden et al., 2008; Franke et al., 2010; Hildebrandt et al., 2010a; Dubska et al., 2012; Palomar et al., 2012; Hornok et al., 2013; Kang et al., 2013). The involvement of birds and their ticks in the life cycle of A. phagocytophilum has also been tested in a transmission study in the US. For the two bird species [American robin (Turdus migratorius) and Gray catbird (Dumetella carolinensis)] involved, no significant role in the life cycle was found (Johnston et al., 2013). However, the establishment of ticks in a new habitat depends on the density of hosts in that area, the habitat structure, and the character of the local microclimate and its changes (Daniel, 1993). As an example of this complexity, Figure 1 shows a summary of several direct and indirect factors which are influencing the occurrence and the spread of A. phagocytophilum to humans.

\section{GEOGRAPHIC DISTRIBUTION AND GENETIC VARIATION}

As already shown in Tables 3-8, A. phagocytophilum has a wide geographical distribution. However, there is a huge lack of knowledge on ecology, epidemiology and source attributions, vector biology and the clinical implication of different pathogenic strains, related to risk posed on animals and humans (Zhang et al., 2013). This intercepts with the development of effective prevention, control, and eradication strategies for A. phagocytophilum. As already mentioned, transovarial transmission does not seem to occur in tick species associated with infection of humans or animals and the dependence on reservoir animals for maintenance of infection in nature seems crucial (Ogden et al., 1998; Liz et al., 2002). Understanding the extent and mechanisms behind bacterial strain diversity, geographical distribution, and host-pathogen fitness on vector and animal level is increasingly important to give accurate estimates to veterinary and public health risks. Former and future developments in methodologies in molecular epidemiology and genetic fingerprinting like multi-locus sequence typing (MLST), pulse field gel electrophoresis (PFGE), high throughput genome sequencing, blood meal genetic analyses, and the study of microbiomes by for instance metagenomic analyses are powerful approaches to delineating bacterial population structures and the evolutionary processes that underlie these (Dumler et al., 2003; Bown et al., 2007; Dark et al., 2012).

A. phagocytophilum is currently viewed as a single bacterial species, seemingly capable of infecting a broad range of 


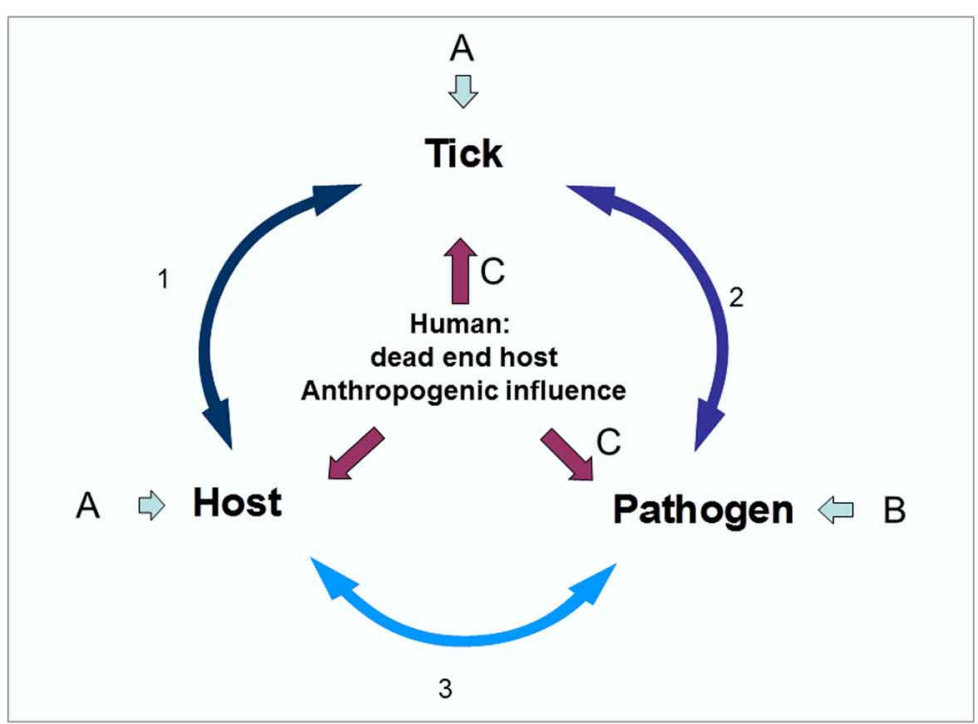

A Availability of ticks and hosts:
$\checkmark$ Land structure
$\checkmark$ Land use and management
$\checkmark$ Habitat fragmentation
$\checkmark$ Climate and climate change
$\checkmark$ Survival rate of ticks
$\checkmark$ Spread through travel and trade
1 . Tick-host-relationship
$\checkmark$ Availability and number of
hosts
$\checkmark$ Questing behaviour of the tick
$\checkmark$ Tick-host-encounter rates
$\checkmark$ Duration of bloodmeal

\section{B Availability and persistence of the pathogen: \\ $\checkmark$ Spread through travel and trade \\ $\checkmark$ Development of resistence}

\author{
2. Tick-pathogen-relationship \\ $\checkmark$ Duration of infection in the tick \\ $\checkmark$ Vector competence of the tick \\ $\checkmark$ Efficiency of transstadial \\ transmission
}

C Encounter rate of humans and tick/pathogen:

$\checkmark$ Recreational or work activities

$\checkmark$ Demographic changes

$\checkmark$ Self-protection

3. Host-pathogen-relationship: $\checkmark$ Susceptibility of the host

$\checkmark$ Length and level of infection

FIGURE 1 | Direct, indirect, and anthropogenic influences on the tick-host-pathogen relationship of Anaplasma phagocytophilum.

hosts based on $16 S$ rRNA gene analyses. The appearance of $16 S$ rRNA gene variants in ticks seems to be dependent on the habitat structure and therefore of the occurrence of specific potential reservoir hosts, which supports the theory of a host association of some variants (Overzier et al., 2013a,b). The situation appears to be even more complex and delicate in its partiality for certain hosts than previously foreseen, when high resolution methods are used to further delineate strains at host level. Strain variation with potential specific host tropism seems to be abundant in A. phagocytophilum and as such, this has to be taken into account when considering the spread of infection, and the contribution of wildlife such as wild ruminant species in infection cycles involving domestic animals and humans.

A. phagocytophilum is sometimes seen to circulate between hosts sharing similar ecological niches (Al-Khedery et al., 2012; Michalik et al., 2012). For example, phylogenetic investigations of the groEL gene have revealed a clustering of sequences into those from roe deer and those from others, as well as a clustering according to geographic origin (Alberti et al., 2005a,b; Silaghi et al., 2011c,d).

Investigations on several A. phagocytophilum strains from different hosts in California indicated that multiple unique strains of
A. phagocytophilum with distinct host tropisms exist (Rejmanek et al., 2012). Furthermore, one study in the Western US showed no overlap in the endemic cycles found with variants from HGA cases and from the suggested wild-life reservoir, the dusky-footed wood rat (Foley et al., 2008a,b).

A. phagocytophilum $16 S$ rRNA gene variants and possibly also $m s p 4$, groEL or ankA gene variants, may cycle differently in the blood of infected hosts, however, the epidemiological consequences of cyclic variation during persistent infection in different hosts are still unknown (Granquist et al., 2010c). The MSP4 is believed to be involved in the host-pathogen interaction and therefore may show host specific characteristics due to selective pressures exerted by the host immune systems, thus a high sequence heterogeneity is observed among A. phagocytophilum strains in this particular gene (Massung et al., 2003; de la Fuente et al., 2005a). Red deer for instance, previously shown to carry strains that show similarities with ovine strains in the $16 \mathrm{~S} r \mathrm{RNA}$ (100\%) and ank (99\%) gene sequences (Stuen et al., 2001), have recently been shown to carry $m s p 4$ genotypes that appear distinct from sheep variants (Stuen et al., 2013). This stands in contrast to earlier assumptions that red deer and occasionally roe deer may contribute to a natural transmission cycle in Europe, also involving livestock and humans (Alberdi et al., 2000; Rymaszewska, 
2008). Characterization of variations in the msp4 sequence, have shown similar structures of strains isolated from humans and dogs in the US (de la Fuente et al., 2005a). Homologous isolates from horse and donkey in California and Italy, respectively, and separate clustering in ruminants are additional examples of evolutionary aspects related to host susceptibility and geographical distribution of this organism (de la Fuente et al., 2005a). Similar patterns have been observed when comparing human, $\mathrm{dog}$, and rodent strains with horse and ruminant strains based on components of the type IV secretion system (Al-Khedery et al., 2012). A German roe deer strain is different in the MSP4 by 23 amino acid changes, compared to the HZ-reference strain representing an outlier of the diversity within the species (de la Fuente et al., 2005a; Ladbury et al., 2008). The diversity of partial $m s p 4$ gene in Norwegian sheep and Austrian wild ungulates have shown great variation in sequence types (Ladbury et al., 2008; Silaghi et al., 2011b), while little heterogeneity has been shown for this gene among isolates from horses (Silaghi et al., 2011b,d).

Investigations of the variable part of the $m s p 2$ ( $p 44$ ) gene have shown a clustering into variants obtained from ruminant species and those from dogs, horses, and humans, as well as a clustering into those from Europe and the US (Silaghi et al., 2011b,d).

The ank gene has also been used to assess the degree of phylogenetic relationship between strains of A. phagocytophilum as this gene is considered less conserved among strains and even more appropriate for high resolution phylogenetic studies (Massung et al., 2000; von Loewenich et al., 2003). In one study, ankA gene sequences were found to separate into four clearly distinct clusters. Sequences from dogs, humans, horses, and cats were found exclusively in cluster I, whereas samples from sheep, cows, European bison, and red deer were parts of clusters I and IV. Roe deer sequences were almost exclusively contained in clusters II and III. Based on these results, roe deer seems unlikely to be reservoir of human granulocytic anaplasmosis (Scharf et al., 2011), which supports the findings from studies mentioned earlier.

\section{RESEARCH GOALS AND APPROACHES}

Thus far, it is not clear if the differences in infection rates in vectors and hosts outlined above truly reflect differences in vector competency of the vector species and reservoir competency of the host species or whether they reflect differences in the

\section{REFERENCES}

Adaszek, L., Klimiuk, P., Skrzypczak, M., Gorna, M., Zietek, J., and Winiarczyk, S. (2012). The identification of Anaplasma spp. isolated from fallow deer (Dama dama) on a free-range farm in eastern Poland. Pol. J. Vet. Sci. 15, 393-394. doi: 10.2478/v10181-0120060-0

Adelson, M. E., Rao, R. V., Tilton, R. C., Cabets, K., Eskow, E., Fein, L., et al. (2004). Prevalence of Borrelia burgdorferi, Bartonella spp., Babesia microti, and
Anaplasma phagocytophila in Ixodes scapularis ticks collected in Northern New Jersey. J. Clin. Microbiol. 42, 2799-2801. doi: 10.1128/JCM.42.6.2799-2801.2004

Akkoyunlu, M., Malawista, S. E., Anguita, J., and Fikrig, E. (2001). Exploitation of interleukin-8induced neutrophil chemotaxis by the agent of human granulocytic ehrlichiosis. Infect. Immun. 69, 5577-5588. doi: 10.1128/IAI.69.9.5577-5588.2001

Alberdi, M. P., Walker, A. R., and Urquhart, K. A. (2000). Field

opportunities to acquire the infections (i.e., encounter rates). Previous studies have indicated the existence of enzootic cycles of gene variants in relation to species of ticks and hosts. The knowledge about infection cycles are important for infection and disease control in domestic animals and humans. Future studies should therefore investigate the relationship between genetic strains of A. phagocytophilum, ticks and different hosts, by genetic fingerprinting and blood meal analysis in order to unravel the ecology and phylogeographic distribution of A. phagocytophilum in nature for evidence based risk assessment and risk management. Vector competence of different tick species should be studied, especially considering the potential niche cycles and great variety of strains and variations in the different geographic areas. Which hosts and vectors that competently can keep which variants in endemic cycles in nature should be unraveled.

Further studies should investigate pathogenesis and mechanisms of persistence in host infections. The complexity of cellular and humoral immune responses in rickettsial diseases may be important targets of prophylactic and metaphylactic treatment strategies to control and cure infections by A. phagocytophilum in animals and humans. Factors involve in pathogenicity of the different variants should therefore be elucidated.

Cell culturing and novel molecular tools allow for rapid sequencing and annotation of whole genome structure. Several comprehensive contributions on A. phagocytophilum proteomics from experimental studies in culture systems, tick- and mouse models have been provided (Lin et al., 2011; Troese et al., 2011; Mastronunzio et al., 2012; Kahlon et al., 2013). However, tick and ruminant host interactions with highly pathogenic strains of the bacterium, like the Norwegian Sheep variant 1 (Stuen et al., 2002), should be studied by use of proteomic approaches to reveal key elements for future control strategies in management of this intrusive disease in livestock production. Longitudinal studies to investigate antigenic variation on genomic levels during persistent infections may reveal hitherto unknown mechanisms of immune evasion and persistence, useful in development of diagnostic and therapeutic approaches. To achieve prophylaxis by vaccination further studies on mechanisms of immune evasion and infection strategies are required. The whole genome of several variants of the bacterium has to be sequenced in order to do comparative genomics and develop proper recombinant vaccine antigens for future cross-infection studies.

evidence that roe deer (Capreolus capreolus) are a natural host for Ehrlichia phagocytophila. Epidemiol. Infect. 124, 315-323. doi: 10.1017/S0950268899003684

Alberdi, M. P., Walker, A. R., Paxton, E. A., and Sumption, K. J. (1998). Natural prevalence of infection with Ehrlichia (Cytoecetes) phagocytophila of Ixodes ricinus ticks in Scotland. Vet. Parasitol. 78, 203-213. doi: 10.1016/S0304-4017 (98)00138-1

Alberti, A., Zobba, R., Chessa, B., Addis, M. F., Sparagano, O., Pinna
Parpagliam, M. L., et al. (2005a). Equine and canine Anaplasma phagocytophilum strains isolated on the island of Sardinia (Italy) are phylogenetically related to pathogenic strains from the United States. Appl. Environ. Microbiol. 71, 6418-6422. doi: 10.1128/AEM.71. 10.6418-6422.2005

Alberti, A., Addis, M. F., Sparagano, O., Zobba, R., Chessa, B., Cubeddu, T., et al. (2005b). Anaplasma phagocytophilum, Sardinia, Italy. Emerg. Infect. Dis. 11, 1322-1324. doi: 10.3201/eid1108.050085 
Alekseev, A. N., Dubinina, H. V., Van De Pol, I., and Schouls, L. M. (2001a). Identification of Ehrlichia spp. and Borrelia burgdorferi in Ixodes ticks in the Baltic regions of Russia. J. Clin. Microbiol. 39, 2237-2242. doi: 10.1128/JCM.39.6.2237-2242.2001

Alekseev, A. N., Dubinina, H. V., Semenov, A. V., and Bolshakov, C. V. (2001b). Evidence of ehrlichiosis agents found in ticks (Acari: Ixodidae) collected from migratory birds. J. Med. Entomol. 38, 471-474. doi: $\quad 10.1603 / 0022-2585-38$. 4.471

Al-Khedery, B., Lundgren, A. M., Stuen, S., Granquist, E. G., Munderloh, U. G., Nelson, C. M., et al. (2012). Structure of the type IV secretion system in different strains of Anaplasma phagocytophilum. BMC Genomics 13:678. doi: 10.1186/1471-2164-13-678

Alleman, A. R., Barbet, A. F., Sorenson, H. L., Strik, N. I., Wamsley, H. L., Wong, S. J., et al. (2006). Cloning and expression of the gene encoding the major surface protein 5 (MSP5) of Anaplasma phagocytophilum and potential application for serodiagnosis. Vet. Clin. Pathol. 35, 418-425. doi: 10.1111/j.1939165X.2006.tb00158.x

Anderson, B. E., Dawson, J. E., Jones, D. C., and Wilson, K. H. (1991). Ehrlichia chaffeensis, a new species associated with human ehrlichiosis. J. Clin. Microbiol. 29, 2838-2842.

Anonymous. (2002). Notification that new names and new combinations have appeared in volume 51, part 6, of the IJSEM. Int. J. Syst. Evol. Microbiol. 52, 5-6.

Aureli, S., Foley, J. E., Galuppi, R., Rejmanek, D., Bonoli, C., and Tampieri, M. P. (2012). Anaplasma phagocytophilum in ticks from parks in the Emilia-Romagna region of northern Italy. Vet. Ital. 48, 413-423.

Bakken, J. S., and Dumler, J. S. (2006). Clinical diagnosis and treatment of human granulocytic anaplasmosis. Ann. N.Y. Acad. Sci. 1078, 236-247. doi: 10.1196/annals.1374.042

Bakken, J. S., and Dumler, J. S. (2008). Human granulocytic anaplasmosis. Infect. Dis. Clin. North Am. 22, 433-448. doi: 10.1016/j.idc.2008.03.011

Bakken, J. S., Dumler, J. S., Chen, S. M., Eckman, M. R., Van Etta, L. L., and Walker, D. H. (1994). Human granulocytic ehrlichiosis in the upper Midwest United States. A new species emerging? J. Am. Med.
Assoc. 272, 212-218. doi: 10.1001/ jama.1994.03520030054028

Baldridge, G. D., Scoles, G. A., Burkhardt, N. Y., Schloeder, B., Kurtti, T. J., and Munderloh, U. G. (2009). Transovarial transmission of Francisella-like endosymbionts and Anaplasma phagocytophilum variants in Dermacentor albipictus (Acari: Ixodidae). J. Med. Entomol. 46, 625-632. doi: 10.1603/033.046.0330

Barandika, J. F., Hurtado, A., GarcíaEsteban, C., Gil, H., Escudero, R., Barral, M., et al. (2007). Tick-borne zoonotic bacteria in wild and domestic small mammals in northern spain. J. Appl. Environ. Microbiol. 73, 6166-6171.

Barbet, A. F., Lundgren, A., Yi, J., Rurangirwa, F. R., and Palmer, G. H. (2000). Antigenic variation of Anaplasma marginale by expression of MSP2 mosaics. Infect. Immun. 68, 6133-6138. doi: 10.1128/IAI.68.11.6133-6138.2000

Barbet, A. F., Meeus, P. F. M., Belanger, M., Bowie, M. V., Yi, J., Lundgren, A. M., et al. (2003). Expression of multiple outer membrane protein sequence variants from a single genomic locus of Anaplasma phagocytophilum. Infect. Immun. 71, 1706-1718. doi: 10.1128/IAI.71.4.1706-1718.2003

Barlough, J. E., Madigan, J. E., Kramer, V. L., Clover, J. R., Hui, L. T., Webb, J. P., et al. (1997a). Ehrlichia phagocytophila genogroup rickettsiae in ixodid ticks from California collected in 1995 and 1996. J. Clin. Microbiol. 35, 2018-2021.

Barlough, J. E., Madigan, J. E., Turoff, D. R., Clover, J. R., Shelly, S. M., and Dumler, J. S. (1997b). An Ehrlichia strain from a llama (Lama glama) and Llama-associated ticks (Ixodes pacificus). J. Clin. Microbiol. 35, 1005-1007.

Bayard-Mc Neeley, M., Bansal, A., Chowdhury, I., Girao, G., Small, C. B., Seiter, K., et al. (2004). In vivo and in vitro studies on Anaplasma phagocytophilum infection of the myeloid cells of a patient with chronic myelogenous leukaemia and human granulocytic ehrlichiosis. J. Clin. Pathol. 57, 499-503. doi: 10.1136/jcp.2003.011775

Beall, M. J., Chandrashekar, R., Eberts, M. D., Cyr, K. E., Diniz, P. P., Mainville, C., et al. (2008). Serological and molecular prevalence of Borrelia burgdorferi, Anaplasma phagocytophilum, and Ehrlichia species in dogs from Minnesota. Vector Borne
Zoonotic Dis. 8, 455-464. doi 10.1089/vbz.2007.0236

Beaufays, J., Adam, B., MentenDedoyart, C., Fievez, L., Grosjean, A., Decrem, Y., et al. (2008). Ir-LBP, an Ixodes ricinus tick salivary LTB4-binding lipocalin, interferes with host neutrophi function. PLoS ONE 3:e3987. doi: 10.1371/journal.pone.0003987

Bell, D. R., Berghaus, R. D., Patel, S., Beavers, S., Fernandez, I., and Sanchez, S. (2012). Seroprevalence of tick-borne infections in military working dogs in the republic of Korea. Vector Borne Zoonotic Dis. 12, 1023-1030. doi 10.1089/vbz.2011.0864

Belongia, E. A., Reed, K. D., Mitchell, P. D., Kolbert, C. P., Persing, D. H., Gill, J. S., et al. (1997). Prevalence of granulocytic Ehrlichia infection among white-tailed deer in Wisconsin. J. Clin. Microbiol. 35, 1465-1468.

Beninati, T., Piccolo, G., Rizzoli, A., Genchi, C., and Bandi, C. (2006). Anaplasmataceae in wild rodents and roe deer from Trento Province (northern Italy). Eur. J. Clin. Microbiol. Infect. Dis. 25 677-678. doi: 10.1007/s10096-0060196-x

Billeter, S. A., Spencer, J. A., Griffin, B., Dykstra, C. C., and Blagburn, B. L. (2007). Prevalence of Anaplasma phagocytophilum in domestic felines in the United States. Vet. Parasitol. 147, 194-198. doi: 10.1016/j.vetpar.2007.03.028

Bjöersdorff, A., Bagert, B., Massung, R. F., Gusa, A., and Eliasson, I. (2002). Isolation and characterization of two European strains of Ehrlichia phagocytophila of equine origin. Clin. Diagn. Lab. Immunol. 9, 341-343.

Bjöersdorff, A., Bergström, S. Massung, R. F., Haeming, P. D. and Olsen, B. (2001). Ehrlichia -infected ticks on migrating birds. Emerg. Infect. Dis. 7 , 877-879.

Bjöersdorff, A., Svendenius, L., Owens, J. H., and Massung, R. F. (1999). Feline granulocytic ehrlichiosis a report of a new clinical entity and characterisation of the infectious agent. J. Small Anim. Pract. 40, 20-24. doi: 10.1111/j.17485827.1999.tb03249.x

Bowman, D., Little, S. E., Lorentzen, L., Shields, J., Sullivan, M. P., and Carlin, E. P. (2009). Prevalence and geographic distribution of Dirofilaria immitis, Borrelia burgdorferi, Ehrlichia canis, and Anaplasma phagocytophilum in dogs in the United States: results of a national clinic-based serologic survey. Vet. Parasitol. 160, 138-148. doi: 10.1016/j.vetpar.2008. 10.093

Bown, K. J., Begon, M., Bennett, M., Birtles, R. J., Burthe, S., Lambin, X., et al. (2006). Sympatric Ixodes trianguliceps and Ixodes ricinus ticks feeding on field voles (Microtus agrestis): potential for increased risk of Anaplasma phagocytophilum in the United Kingdom. Vector Borne Zoonotic Dis. 6, 404-410. doi: 10.1089/vbz.2006.6.404

Bown, K. J., Begon, M., Bennett, M., Woldehiwet, Z., and Ogden, N. H. (2003). Seasonal dynamics of Anaplasma phagocytophila in a rodent-tick (Ixodes trianguliceps) system, United Kingdom. Emerg. Infect. Dis. 9, 63-70. doi: 10.3201/eid0901.020169

Bown, K. J., Lambin, X., Ogden, N. H., Begon, M., Telford, G., Woldehiwet, Z., et al. (2009). Delineating Anaplasma phagocytophilum ecotypes in coexisting, discrete enzootic cycles. Emerg. Infect. Dis. 15, 1948-1954. doi: 10.3201/eid1512.090178

Bown, K. J., Lambin, X., Ogden, N. H., Petrovec, M., Shaw, S. E. Woldehiwet, Z., et al. (2007). High-resolution genetic fingerprinting of European strains of Anaplasma phagocytophilum by use of multilocus variable-number tandem-repeat analysis. J. Clin. Microbiol. 45, 1771-1776. doi: 10.1128/JCM.00365-07

Bown, K. J., Lambin, X., Telford, G., Heyder-Bruckner, D., Ogden, N. H., and Birtles, R. J. (2011). The common shrew (Sorex araneus): a neglected host of tick-borne infections. Vector Borne Zoonotic Dis. 11, 947-953. doi: 10.1089/vbz.2010.0185

Bown, K. J., Lambin, X., Telford, G. R., Ogden, N. H., Telfer, S., Woldehiwet, Z., et al. (2008). Relative importance of Ixodes ricinus and Ixodes trianguliceps as vectors for Anaplasma phagocytophilum and Babesia microti in field vole (Microtus agrestis) populations. Appl. Environ. Microbiol. 74, 7118-7125. doi: 10.1128/AEM.00625-08

Bray, D. P., Bown, K. J., Stockley, P., Hurst, J. L., Bennett, M., and Birtles, R. J. (2007). Haemoparasites of common shrews (Sorex araneus) in Northwest England. Parasitology 134, 819-826. doi: $10.1017 / \mathrm{S} 0031182007002302$

Brodie, T. A., Holmes, P. H., and Urquhart, G. M. (1986). Some aspects of tick-borne diseases 
of British sheep. Vet. Rec. 118, 415-418. doi: 10.1136/vr.118. 15.415

Brouqui, P., and Matsumoto, K. (2007). "Bacteriology and phylogeny of Anaplasmataceae," in Rickettsial Diseases, eds D. Raoult and P. Parola (New York, NY: Informa Healthcare, USA, Inc.), 179-198. doi: 10.3109/9781420019971.013

Burri, C., Dupasquier, C., Bastic, V., and Gern, L. (2011). Pathogens of emerging tick-borne diseases, Anaplasma phagocytophilum, Rickettsia spp., and Babesia spp., in Ixodes ticks collected from rodents at four sites in Switzerland (Canton of Bern). Vector Borne Zoonotic Dis. 11, 939-944. doi: 10.1089/vbz.2010.0215

Butler, C. M., Nijhof, A. M., Jongejan, F., and Van Der Kolk, J. H. (2008). Anaplasma phagocytophilum infection in horses in the Netherlands. Vet. Rec. 162, 216-217. doi: 10.1136/vr.162.7.216

Campbell, R. S. F., Rowland, A. C., and Scott, G. R. (1994). Sequential pathology of tick-borne fever. J. Comp. Pathol. 111, 303-313. doi: 10.1016/S0021-997580009-X

Canales, M., Labruna, M. B., Soares, J. F., Prudencio, C. R., and de la Fuente, J. (2009). Protective efficacy of bacterial membranes containing surface-exposed BM95 antigenic peptides for the control of cattle tick infestations. Vaccine 27, 7244-7248. doi: 10.1016/j.vaccine.2009.09.123

Cao, W. C., Zhan, L., He, J., Foley, J. E., Sj, D. E. V., Wu, X. M., et al. (2006). Natural Anaplasma phagocytophilum infection of ticks and rodents from a forest area of Jilin Province, China. Am. J. Trop. Med. Hyg. 75, 664-668.

Cao, W. C., Zhao, Q. M., Zhang, P. H., Dumler, J. S., Zhang, X. T., Fang, L. Q., et al. (2000). Granulocytic Ehrlichiae in Ixodes persulcatus ticks from an area in China where Lyme disease is endemic. J. Clin. Microbiol. 38, 4208-4210.

Cao, W. C., Zhao, Q. M., Zhang, P. H., Yang, H., Wu, X. M., Wen, B. H., et al. (2003). Prevalence of Anaplasma phagocytophila and Borrelia burgdorferi in Ixodes persulcatus ticks from northeastern China. Am. J. Trop. Med. Hyg. 68, 547-550.

Capelli, G., Ravagnan, S., Montarsi, F., Ciocchetta, S., Cazzin, S., Porcellato, E., et al. (2012). Occurrence and identification of risk areas of Ixodes ricinus-borne pathogens: a cost-effectiveness analysis in north-eastern Italy. Parasit. Vectors 5:61. doi: 10.1186/1756-3305-5-61

Carlyon, J. A., Akkoyunlu, M., Xia, L. J., Yago, T., Wang, T., Cummings, R. D., et al. (2003). Murine neutrophils require alpha 1, 3-fucosylation but not PSGL-1 for productive infection with Anaplasma phagocytophilum. Blood 102, 3387-3395. doi: 10.1182/blood-2003-02-0621

Carpi, G., Cagnacci, F., Neteler, M., and Rizzoli, A. (2008). Tick infestation on roe deer in relation to geographic and remotely sensed climatic variables in a tickborne encephalitis endemic area. Epidemiol. Infect. 136, 1416-1424. doi: 10.1017/S0950268807000039

Castellaw, A. H., Chenney, E. F., and Varela-Stokes, A. S. (2011). Tickborne disease agents in various wildlife from Mississippi. Vector Borne Zoonotic Dis. 11, 439-442. doi: 10.1089/vbz.2009.0221

Castro, M. B., Nicholson, W. L., Kramer, V. L., and Childs, J. E. (2001). Persistent infection in Neotoma fuscipes (Muridae: Sigmodontinae) with Ehrlichia phagocytophila sensu lato. Am. J. Trop. Med. Hyg. 65, 261-267.

Chae, J. S., Yu do, H., Shringi, S., Klein, T. A., Kim, H. C., Chong, S. T., et al. (2008). Microbial pathogens in ticks, rodents and a shrew in northern Gyeonggi-do near the DMZ, Korea. J. Vet. Sci. 9, 285-293. doi: 10.4142/jvs.2008.9.3.285

Chen, G., Severo, M. S., Sohail, M., Sakhon, O. S., Wikel, S. K., Kotsyfakis, M., et al. (2012). Ixodes scapularis saliva mitigates inflammatory cytokine secretion during Anaplasma phagocytophilum stimulation of immune cells. Parasit. Vectors 5:229. doi: 10.1186/1756-3305-5-229

Chen, S.-M., Dumler, J. S., Bakken, J. S., and Walker, D. H. (1994) Identification of a granulocytic Ehrlichia species as the etiologic agent of human disease. J. Clin. Microbiol. 32, 589-595.

Chmielewska-Badora, J., Zwolinski, J., Cisak, E., Wojcik-Fatla, A., Buczek, A., and Dutkiewicz, J. (2007). Prevalence of Anaplasma phagocytophilum in Ixodes ricinus ticks determined by polymerase chain reaction with two pairs of primers detecting $16 \mathrm{~S}$ rRNA and ankA genes. Ann. Agric. Environ. Med. 14, 281-285.

Choi, K. S., Garyu, J., Park, J., and Dumler, J. S. (2003). Diminished adhesion of Anaplasma phagocytophilum-infected neutrophils to endothelial cells is associated with reduced expression of leukocyte surface selectin. Infect. Immun. 71, 4586-4594. doi: 10.1128/IAI.71.8.4586-4594.2003

Choi, K. S., Grab, D. J., and Dumler, J. S. (2004). Anaplasma phagocytophilum infection induces protracted neutrophil degranulation. Infect. Immun. 72, 3680-3683. doi: 10.1128/IAI.72.6.3680-3683.2004

Choi, K. S., Park, J. T., and Dumler, J. S. (2005). Anaplasma phagocytophilum delay of neutrophil apoptosis through the p38 mitogen-activated protein kinase signal pathway. Infect. Immun. 73, 8209-8218. doi: 10.1128/IAI.73.12.8209-8218.2005

Christová, I., and Gladnishka, T. (2005). Prevalence of infection with Francisella tularensis, Borrelia burgdorferi sensu lato and Anaplasma phagocytophilum in rodents from an endemic focus of tularemia in Bulgaria. Ann. Agric. Environ. Med. 12, 149-152.

Christová, I., Schouls, L., van De Pol, I., Park, J., Panayotov, S., Lefterová, V., et al. (2001). High prevalence of granulocytic Ehrlichiae and Borrelia burgdorferi sensu lato in Ixodes ricinus ticks from Bulgaria. J. Clin. Microbiol. 39, 4172-4174. doi: 10.1128/JCM.39.11.4172-4174.2001 Cinco, M., Padovan, D., Murgia, R. Maroli, M., Frusteri, L., Heldtander, M., et al. (1997). Coexistence of Ehrlichia phagocytophila and Borrelia burgdorferi sensu lato in Ixodes ricinus ticks from Italy as determined by $16 \mathrm{~S}$ rRNA gene sequencing. J. Clin. Microbiol. 35, 3365-3366.

Clark, K. L. (2012). Anaplasma phagocytophilum in small mammals and ticks in northeast Florida. J. Vector Ecol. 37, 262-268. doi 10.1111/j.1948-7134.2012.00226.x

Cockwill, K. R., Taylor, S. M., Snead, E. C., Dickinson, R., Cosford, K., Malek, S., et al. (2009). Granulocytic anaplasmosis in three dogs from Saskatoon, Saskatchewan. Can. Vet. J. 50, 835-840.

Cohn, L. A. (2003). Ehrlichiosis and related infections. Vet. Clin. North Am. Small Anim. Pract. 33, 863-884. doi: 10.1016/S0195-561600031-7

Cotté, V., Bonnet, S., Cote, M. and Vayssier-Taussat, M. (2010). Prevalence of five pathogenic agents in questing Ixodes ricinus ticks from western France. Vector Borne Zoonotic Dis. 10, 723-730. doi: 10.1089/vbz.2009.0066

Courtney, J. W., Dryden, R. L., Montgomery, J., Schneider, B. S., Smith, G., and Massung, R. F. (2003). Molecular characterization of Anaplasma phagocytophilum and
Borrelia burgdorferi in Ixodes scapularis ticks from Pennsylvania. J. Clin. Microbiol. 41, 1569-1573. doi: 10.1128/JCM.41.4.1569-1573.2003

Courtney, J. W., Kostelnik, L. M., Zeidner, N. S., and Massung, R. F. (2004). Multiplex realtime PCR for detection of Anaplasma phagocytophilum and Borrelia burgdorferi. J. Clin. Microbiol. 42, 3164-3168. doi: 10.1128/JCM.42.7.3164-3168.2004

Daniel, M. (1993). Influence of the microclimate on the vertical distribution of the tick Ixodes ricinus (L.) in central Europe. Acarologia 34, 105-113.

Daniels, T. J., Battaly, G. R., Liveris, D., Falco, R. C., and Schwartz, I. (2002). Avian reservoirs of the agent of human granulocytic ehrlichiosis. Emerg. Infect. Dis. 8, 1524-1525. doi: 10.3201/eid0812.010527

Dark, M. J., Lundgren, A. M., and Barbet, A. F. (2012). Determining the repertoire of immunodominant proteins via whole-genome amplification of intracellular pathogens. PLoS ONE 7:e36456. doi: 10.1371/journal.pone.0036456

de Carvalho, I. L., Milhano, N., Santos, A. S., Almeida, V., Barros, S. C., De Sousa, R., et al. (2008). Detection of Borrelia lusitaniae, Rickettsia sp. IRS3, Rickettsia monacensis, and Anaplasma phagocytophilum in Ixodes ricinus collected in Madeira Island, Portugal. Vector Borne Zoonotic Dis. 8, 575-579. doi: 10.1089/vbz.2007.0245

de la Fuente, J., Ayoubi, P., Blouin, E. F., Almazán, C., Naranjo, V., Kocan, K. M. (2006a). Anaplasmosis: focusing on host-vector-pathogen interactions for vaccine development. Ann. N.Y. Acad. Sci. 1078, 416-423. doi: 10.1196/annals.1374.081

de la Fuente, J., Almazán, C., BlasMachado, U., Naranjo, V., Mangold, A. J., Blouin, E. F., et al. (2006b). The tick protective antigen, 4D8, is a conserved protein involved in modulation of tick blood ingestion and reproduction. Vaccine 24, 4082-4095.

de la Fuente, J., Almazán, C., Blouin, E. F., Naranjo, V., and Kocan, K. M. (2006c). Reduction of tick infections with Anaplasma marginale and A. phagocytophilum by targeting the tick protective antigen subolesin. Parasitol. Res. 100, 85-91. doi: 10.1007/s00436-006-0244-6

de la Fuente, J., Blouin, E. F., ManzanoRoman, R., Naranjo, V., Almazán, C., Pérez de la Lastra, J. M., et al. (2007). Functional genomic studies of tick cells in response to infection with the cattle pathogen, Anaplasma 
marginale. Genomics 90, 712-722. doi: 10.1016/j.ygeno.2007.08.009

de la Fuente, J., and Kocan, K. M. (2006). Strategies for development of vaccines for control of ixodid ticks species. Parasite Immunol. 28, 275-283. doi: 10.1111/j.13653024.2006.00828.x

de la Fuente, J., Massung, R. F., Wong, S. J., Chu, F. K., Lutz, H., Meli, M., et al. (2005a). Sequence analysis of the msp4 gene of Anaplasma phagocytophilum strains. J. Clin. Microbiol. 43, 1309-1317. doi: 10.1128/JCM.43.3.1309-1317. 2005

de la Fuente, J., Naranjo, V., RuizFons, F., Hofle, U., Fernandez De Mera, I. G., Villanua, D., et al. (2005b). Potential vertebrate reservoir hosts and invertebrate vectors of Anaplasma marginale and A. phagocytophilum in central Spain. Vector Borne Zoonotic Dis. 5, 390-401. doi: 10.1089/vbz.2005. 5.390

de la Fuente, J., Ruiz-Fons, F., Naranjo, V., Torina, A., Rodriguez, O., and Gortazar, C. (2008). Evidence of Anaplasma infections in European roe deer (Capreolus capreolus) from southern Spain. Res. Vet. Sci. 84, 382-386. doi: 10.1016/j.rvsc.2007.05.018

DeNatale, C. E., Burkot, T. R., Schneider, B. S., and Zeidner, N. S. (2002). Novel potential reservoirs for Borrelia sp. and the agent of human granulocytic ehrlichiosis in Colorado. J. Wildl. Dis. 38, 478-482.

Derdáková, M., Halanová, M., Stanko, M., Štefanèíková, A., Cislaková, L., and Pet'ko, B. (2003). Molecular evidence for Anaplasma phagocytophilum and Borrelia burgdorferi sensu lato in Ixodes ricinus ticks from eastern Slovakia. Ann. Agric. Environ. Med. 10, 269-271.

Derdáková, M., Štefanèíková, A., Špitalská, E., Taragel'ová, V., Košt'álová, T., Hrkl'ová, G., et al. (2011). Emergence and genetic variability of Anaplasma species in small ruminants and ticks from Central Europe. Vet. Microbiol. 153, 293-298. doi: 10.1016/j.vetmic.2011.05.044

Des Vignes, F., Levin, M. L., and Fish, D. (1999). Comparative vector competence of Dermacentor variabilis and Ixodes scapularis (Acari: Ixodidae) for the agent of human granulocytic ehrlichiosis. J. Med. Entomol. 36, 182-185.

Drazenovich, N., Foley, J., and Brown, R. N. (2006). Use of real-time quantitative PCR targeting the msp2 protein gene to identify cryptic Anaplasma phagocytophilum infections in wildlife and domestic animals. Vector Borne Zoonotic Dis. 6, 83-90. doi: 10.1089/vbz.2006.6.83

Dubska, L., Literak, I., Kverek, P., Roubalova, E., Kocianova, E., and Taragelova, V. (2012). Tick-borne zoonotic pathogens in ticks feeding on the common nightingale including a novel strain of Rickettsia sp. Ticks Tick Borne Dis. 3, 265-268. doi: 10.1016/j.ttbdis.2012.06.001

Dugan, V. G., Yabsley, M. J., Tate, C. M., Mead, D. G., Munderloh, U. G., Herron, M. J., et al. (2006). Evaluation of white-tailed deer (Odocoileus virginianus) as natural sentinels for Anaplasma phagocytophilum. Vector Borne Zoonotic Dis. 6, 192-207. doi: 10.1089/vbz.2006.6.192

Dumler, J. S. (1996). "Human ehrlichiosis: clinical, laboratory, epidemiologic, and pathologic considerations," in Rickettsiae and Rickettsial Diseases, eds J. Kazár and R. Toman (Bratislava: Veda), 287-302.

Dumler, J. S. (2012). The biological basis of severe outcomes in Anaplasma phagocytophilum infection. FEMS Immunol. Med. Microbiol. 64, 13-20. doi: 10.1111/j.1574-695X.2011.00909.x

Dumler, J. S., Asanovich, K. M., and Bakken, J. S. (2003). Analysis of genetic identity of North American Anaplasma phagocytophilum strains by pulsed-field gel electrophoresis. J. Clin. Microbiol. 41, 3392-3394. doi: 10.1128/JCM.41.7.3392-3394.2003

Dumler, J. S., Barbet, A. F., Bekker, C. P., Dasch, G. A., Palmer, G. H., Ray, S C., et al. (2001). Reorganization of genera in the families Rickettsiaceae and Anaplasmataceae in the order Rickettsiales; unification of some species of Ehrlichia with Anaplasma, Cowdria with Ehrlichia and Ehrlichia with Neorickettsia, descriptions of six new species combinations and designation of Ehrlichia equi and "HGE agent" as subjective synonyms of Ehrlichia phagocytophila. Int. J. Syst. Evol. Microbiol. 51, 2145-2165. doi: 10.1099/00207713-51-6-2145

Dumler, J. S., Madigan, J. E., Pusterla, N., and Bakken, J. S. (2007). Ehrlichiosis in humans: epidemiology, clinical presentation, diagnosis, and treatment. Clin. Infect. Dis. 15, 45(Suppl. 1), S45-S51.

Ebani, V. V., Verin, R., Fratini, F., Poli, A., and Cerri, D. (2011). Molecular survey of Anaplasma phagocytophilum and Ehrlichia canis in red foxes (Vulpes vulpes) from central Italy. J. Wildl. Dis. 47, 699-703.

Egenvall, A., Lilliehook, I., Bjoersdorff, A., Engvall, E. O., Karlstam, E., Artursson, K., et al. (2000). Detection of granulocytic Ehrlichia species DNA by PCR in persistently infected dogs. Vet. Rec. 146, 186-190. doi: 10.1136/vr.146.7.186

Egenvall, A. E., Hedhammar, A. A., and Bjöersdorff, A. (1997). Clinical features and serology of 14 dogs affected by granulocytic ehrlichiosis in Sweden. Vet. Rec. 140, 222-226. doi: 10.1136/vr.140.9.222

Egyed, L., Elo, P., Sreter-Lancz, Z., Szell, Z., Balogh, Z., and Sreter, T. (2012). Seasonal activity and tickborne pathogen infection rates of Ixodes ricinus ticks in Hungary. Ticks Tick Borne Dis. 3, 90-94. doi: 10.1016/j.ttbdis.2012.01.002

Eremeeva, M. E., Oliveira, A., Robinson, J. B., Ribakova, N., Tokarevich, N. K., and Dasch, G. A. (2006). Prevalence of bacterial agents in Ixodes persulcatus ticks from the Vologda Province of Russia. Ann. N.Y Acad. Sci. 1078, 291-298. doi: 10.1196/annals.1374.054

Ferquel, E., Garnier, M., Marie, J., Bernede-Bauduin, C., Baranton, G., Perez-Eid, C., et al. (2006). Prevalence of Borrelia burgdorferi sensu lato and Anaplasmataceae members in Ixodes ricinus ticks in Alsace, a focus of Lyme borreliosis endemicity in France. Appl. Environ. Microbiol. 72, 3074-3078. doi: 10.1128/AEM.72.4.3074-3078 2006

Fingerle, V., Munderloh, U. G., Liegl, G., and Wilske, B. (1999). Coexistence of ehrlichiae of the phagocytophila group with Borrelia burgdorferi in Ixodes ricinus from Southern Germany. Med. Microbiol. Immunol. 188, 145-149. doi: $10.1007 / \mathrm{s} 004300050117$

Foggie, A. (1951). Studies on the infectious agent of tick-borne fever in sheep. J. Pathol. Bacteriol. 63, 1-15. doi: $10.1002 /$ path. 1700630103

Foggie, A. (1962). Studies on tick pyaemia and tick-borne fever. Symp. Zoo. Soc. Lond. 6, 51-58.

Foley, J. E., Barlough, J. E., Kimsey, R. B., Madigan, J. E., Derock, E., and Poland, A. (1998). Ehrlichia spp. in cervids from California. J. Wildl. Dis. 34, 731-737.

Foley, J. E., Clueit, S. B., and Brown, R. N. (2008a). Differential exposure to Anaplasma phagocytophilum in rodent species in northern California. Vector Borne Zoonotic Dis. 8, 49-55. doi 10.1089/vbz.2007.0175
Foley, J. E., Nieto, N. C., Adjemian, J., Dabritz, H., and Brown, R. N. (2008b). Anaplasma phagocytophilum infection in small mammal hosts of Ixodes ticks, western United States. Emerg. Infect. Dis. 14, 1147-1150. doi: 10.3201/eid1407.071599

Foley, J. E., Foley, P., Jecker, M., Swift, P. K., and Madigan, J. E. (1999). Granulocytic ehrlichiosis and tick infestation in mountain lions in California. J. Wildl. Dis. 35, 703-709.

Foley, J. E., and Nieto, N. C. (2011). The ecology of tick-transmitted infections in the redwood chipmunk (Tamias ochrogenys). Ticks Tick Borne Dis. 2, 88-93. doi: 10.1016/j.ttbdis.2010.11.003

Foley, J. E., Nieto, N. C., Clueit, S. B., Foley, P., Nicholson, W. N., and Brown, R. N. (2007). Survey for zoonotic rickettsial pathogens in northern flying squirrels, Glaucomys sabrinus, in California. J. Wildl. Dis. 43, 684-689.

Foley, J. E., Rejmanek, D., Fleer, K., and Nieto, N. (2011). Nidicolous ticks of small mammals in Anaplasma phagocytophilum-enzootic sites in northern California. Ticks Tick Borne Dis. 2, 75-80. doi: 10.1016/j.ttbdis.2011.03.003

Franke, J., Meier, F., Moldenhauer, A., Straube, E., Dorn, W., and Hildebrandt, A. (2010). Established and emerging pathogens in Ixodes ricinus ticks collected from birds on a conservation island in the Baltic Sea. Med. Vet. Entomol. 24, 425-432. doi: 10.1111/j.1365-2915. 2010.00905.x

Franzén, P., Aspan, A., Egenvall, A., Gunnarsson, A., Aberg, L., and Pringle, J. (2005). Acute clinical, hematologic, serologic, and polymerase chain reaction findings in horses experimentally infected with a European strain of Anaplasma phagocytophilum. J. Vet. Intern. Med. 9, 232-239

Franzén, P., Aspan, A., Egenvall, A., Gunnarsson, A., Karlstam, E., and Pringle, J. (2009). Molecular evidence for persistence of Anaplasma phagocytophilum in the absence of clinical abnormalities in horses after recovery from acute experimental infection. J. Vet. Intern. Med. 23, 636-642. doi: 10.1111/j.19391676.2009.0317.x

Franzén, P., Berg, A. L., Aspan, A., Gunnarsson, A., and Pringle, J. (2007). Death of a horse infected experimentally with Anaplasma phagocytophilum. Vet. Rec. 160 , 122-125. doi: 10.1136/vr.160. 4.122 
Futse, J. E., Brayton, K. A., Dark, M. J., Knowles, D. P., and Palmer, G. H. (2008). Superinfection as a driver of genomic diversification in antigenically variant pathogens. Proc. Natl. Acad. Sci. U.S.A. 105, 2123-2127. doi: $10.1073 /$ pnas. 0710333105

Gabriel, M. W., Brown, R. N., Foley, J. E., Higley, J. M., and Botzler, R. G. (2009). Ecology of Anaplasma phagocytophilum infection in gray foxes (Urocyon cinereoargenteus) in northwestern California. J. Wildl. Dis. 45, 344-354.

Galindo, R. C., Ayllon, N., Strasek Smrdel, K., Boadella, M., Beltran, B., Mazariegos, M., et al. (2012). Gene expression profile suggests that pigs (Sus scrofa) are susceptible to Anaplasma phagocytophilum but control infection. Parasit. Vectors 5:181. doi: 10.1186/1756-33055-181

Ge, Y., and Rikihisa, Y. (2006). Anaplasma phagocytophilum delays spontaneous human neutrophil apoptosis by modulation of multiple apoptotic pathways. Cell. Microbiol. 8, 1406-1416. doi: 10.1111/j.1462-5822.2006.00720.x

Giudice, E., Giannetto, C., Furco, V., Alongi, A., and Torina, A. (2012). Anaplasma phagocytophilum seroprevalence in equids: a survey in Sicily (Italy). Parasitol. Res. 111, 951-955. doi: 10.1007/s00436-0122854-5

Goethert, H. K., and Telford, S. R. 3rd. (2003). Enzootic transmission of the agent of human granulocytic ehrlichiosis among cottontail rabbits. Am. J. Trop. Med. Hyg. 68, 633-637.

Goodman, J. L., Nelson, C., Vitale, B., Madigan, J. E., Dumler, J. S., Kurtti, T. J., et al. (1996). Direct cultivation of the causative agent of human granulocytic ehrlichiosis. N. Engl. J. Med. 334, 209-215. doi: 10.1056/NEJM199601253340401

Gordon, W. S., Brownlee, A., and Wilson, D. R. (1940). "Studies in louping-ill, tick-borne fever and scrapie," in Proceedings: 3rd International Congress of Microbiology, (New York, NY), 362-363.

Gordon, W. S., Brownlee, A., Wilson, D. R., and MacLeod, J. (1932). "Tick-borne fever" (A hitherto undescribed disease of sheep.). J. Comp. Pathol. 45, 301-307.

Granick, J. L., Armstrong, P. J., and Bender, J. B. (2009). Anaplasma phagocytophilum infection in dogs: 34 cases (2000-2007). J. Am. Vet. Med. Assoc. 234, 1559-1565. doi: 10.2460/javma.234.12.1559
Granick, J. L., Reneer, D. V., Carlyon, J. A., and Borjesson, D. L. (2008). Anaplasma phagocytophilum infects cells of the megakaryocytic lineage through sialylated ligands but falls to alter platelet production. J. Med. Microbiol. 57, 416-423. doi: 10.1099/jmm.0.47551-0

Granquist, E. G., Aleksandersen, M., Bergstrom, K., Dumler, S. J., Torsteinbo, W. O., and Stuen, S. (2010a). A morphological and molecular study of Anaplasma phagocytophilum transmission events at the time of Ixodes ricinus tick bite. Acta Vet. Scand. 52

Granquist, E. G., Bardsen, K., Bergstrom, K., and Stuen, S (2010b). Variant -and individual dependent nature of persistent Anaplasma phagocytophilum infection. Acta Vet. Scand. 52.

Granquist, E. G., Stuen, S., Crosby, L., Lundgren, A. M., Alleman, A. R., and Barbet, A. F. (2010c). Variant-specific and diminishing immune responses towards the highly variable MSP2(P44) outer membrane protein of Anaplasma phagocytophilum during persistent infection in lambs. Vet. Immunol. Immunopathol. 133, 117-124. doi: 10.1016/j.vetimm.2009.07.009

Granquist, E. G., Stuen, S., Lundgren, A. M., Braten, M., and Barbet, A. F. (2008). Outer membrane protein sequence variation in lambs experimentally infected with Anaplasma phagocytophilum. Infect. Immun. 76, 120-126. doi: 10.1128/IAI.01206-07 Gribble, D. H. (1969). Equine ehrlichiosis. J. Am. Vet. Med. Assoc. 155, 462-469.

Grøva, L., Olesen, I., Steinshamn, H., and Stuen, S. (2011). Prevalence of Anaplasma phagocytophilum infection and effect on lamb growth. Acta Vet. Scand. 53:30. doi: 10.1186/1751-0147-53-30

Grzeszczuk, A., Karbowiak, G., Ziarko, S., and Kovalchuk, O. (2006). The root-vole Microtus oeconomus (Pallas, 1776): a new potential reservoir of Anaplasma phagocytophilum. Vector Borne Zoonotic Dis. 6, 240-243. doi: 10.1089/vbz.2006.6.240

Grzeszczuk, A., and Stanczak, J. (2006). Highly variable year-toyear prevalence of Anaplasma phagocytophilum in Ixodes ricinus ticks in northeastern Poland: a 4-year follow-up. Ann. N.Y. Acad. Sci. 1078, 309-311. doi: 10.1196/annals.1374.057

Güner, E. S., Watanabe, M., Kadosaka, T., Polat, E., Gargili, A., Gulanber, A., et al. (2005). Seroepidemiology of Borrelia burgdorferi sensu lato and Anaplasma phagocytophilum in wild mice captured in northern Turkey. Epidemiol. Infect. 133, 331-336. doi 10.1017/S0950268804003309

Guo, X. Y., Booth, C. J., Paley, M. A., Wang, X. M., DePonte, K., Fikrig, E., et al. (2009). Inhibition of neutrophil function by two tick salivary proteins. Infect. Immun. 77, 2320-2329. doi: 10.1128/IAI.0150708

Guy, E., Tasker, S., and Joynson, D. H. (1998). Detection of the agent of human granulocytic ehrlichiosis (HGE) in UK ticks using polymerase chain reaction. Epidemiol. Infect. 121, 681-683. doi: 10.1017/S0950268898001708

Halos, L., Bord, S., Cotté, V., Gasqui, P., Abrial, D., Barnouin, J., et al. (2010) Ecological factors characterizing the prevalence of bacterial tick-borne pathogens in Ixodes ricinus ticks in pastures and woodlands. Appl. Environ. Microbiol. 76, 4413-4420. doi: 10.1128/AEM.00610-10

Halos, L., Vourc'h, G., Cotté, V., Gasqui, P., Barnouin, J., Boulous, H. J., et al. (2006). Prevalence of Anaplasma phagocytophilum, Rickettsia sp. and Borrelia burgdorferi sensu lato DNA in questing Ixodes ricinus ticks from France. Ann. N.Y. Acad. Sci. 1078, 316-319. doi: 10.1196/annals.1374.059

Hamel, D., Bondarenko, A., Silaghi, C., Nolte, I., and Pfister, K. (2012a). Seroprevalence and bacteremia [corrected] of Anaplasma phagocytophilum in cats from Bavaria and Lower Saxony (Germany). Berl. Munch. Tierarztl. Wochenschr. 125, 163-167.

Hamel, D., Silaghi, C., Lescai, D., and Pfister, K. (2012b). Epidemiological aspects on vector-borne infections in stray and pet dogs from Romania and Hungary with focus on Babesia spp. Parasitol. Res. 110, 1537-1545. doi: 10.1007/s00436-011-2659-y

Hansen, M. G., Christoffersen, M. Thuesen, L. R., Petersen, M. R., and Bojesen, A. M. (2010). Seroprevalence of Borrelia burgdorferi sensu lato and Anaplasma phagocytophilum in Danish horses. Acta Vet. Scand. 52:3. doi: 10.1186/1751-0147-52-53

Hapunik, J., Vichova, B., Karbowiak, G., Wita, I., Bogdaszewski, M., and Pet'ko, B. (2011). Wild and farm breeding cervids infections with Anaplasma phagocytophilum. Ann. Agric. Environ. Med. 18, 73-77.

Hartelt, K., Oehme, R., Frank, H. Brockmann, S. O., Hassler, D. and Kimmig, P. (2004). Pathogens and symbionts in ticks: prevalence of Anaplasma phagocytophilum (Ehrlichia sp.), Wolbachia sp., Rickettsia sp., and Babesia sp. in Southern Germany. Int. J. Med. Microbiol. 293(Suppl. 37), 86-92.

Hartelt, K., Pluta, S., Oehme, R., and Kimmig, P. (2008). Spread of ticks and tick-borne diseases in Germany due to global warming. Parasitol. Res. 103(Suppl. 1), S109-S116. doi: 10.1007/s00436-008-1059-4

Heikkilä, H. M., Bondarenko, A., Mihalkov, A., Pfister, K., and Spillmann, T. (2010). Anaplasma phagocytophilum infection in a domestic cat in Finland: case report. Acta Vet. Scand. 52:62. doi: 10.1186/1751-0147-52-62

Heine, S., Thiet, W., and Liebisch, G. (2007). Anaplasmose beim Hund Fallbericht. Prakt. Tierarzt 88, 20-27.

Heinze, D. M., Carmical, J. R., Aronson, J. F., and Thangamani, S. (2012), Early immunologic events at the tick-host interface. PLoS ONE 7:e47301. doi:10.1371/journal.pone.0047301

Henn, J. B., Gabriel, M. W., Kasten, R. W., Brown, R. N., Theis, J. H., Foley, J. E., et al. (2007). Gray foxes (Urocyon cinereoargenteus) as a potential reservoir of a Bartonella clarridgeiae-like bacterium and domestic dogs as part of a sentinel system for surveillance of zoonotic arthropod-borne pathogens in northern California. J. Clin. Microbiol. 45, 2411-2418. doi: 10.1128/JCM.02539-06

Herron, M. J., Ericson, M. E., Kurtti, T. J., and Munderloh, U. G. (2005). The interactions of Anaplasma phagocytophilum, endothelial cells, and human neutrophils. Rickettsioses: from Genome to Proteome, Pathobiology, and Rickettsiae As An International Threat 1063, 374-382.

Herron, M. J., Nelson, C. M., Larson, J., Snapp, K. R., Kansas, G. S., and Goodman, J. L. (2000). Intracellular parasitism by the human granulocytic ehrlichiosis bacterium through the P-selectin ligand, PSGL-1. Science 288, 1653-1656. doi: $10.1126 /$ science.288.5471.1653

Hildebrandt, A., Franke, J., Meier, F., Sachse, S., Dorn, W., and Straube, E. (2010a). The potential role of migratory birds in transmission cycles of Babesia spp., Anaplasma phagocytophilum, and Rickettsia spp. Ticks Tick Borne Dis. 1, 105-107. doi: 10.1016/j.ttbdis.2009.12.003

Hildebrandt, A., Kramer, A., Sachse, S., and Straube, E. (2010b). Detection of Rickettsia spp. and Anaplasma phagocytophilum in 
Ixodes ricinus ticks in a region of Middle Germany (Thuringia). Ticks Tick Borne Dis. 1, 52-56. doi: 10.1016/j.ttbdis.2009.11.005

Hildebrandt, A., Schmidt, K. H., Fingerle, V., Wilske, B., and Straube, E. (2002). Prevalence of granulocytic Ehrlichiae in Ixodes ricinus ticks in Middle Germany (Thuringia) detected by PCR and sequencing of a $16 \mathrm{~S}$ ribosomal DNA fragment. FEMS Microbiol. Lett. 211, 225-230. doi: 10.1111/j.15746968.2002.tb11229.x

Hofmann-Lehmann, R., Meli, M. L., Dreher, U. M., Gonczi, E., Deplazes, P., Braun, U., et al. (2004). Concurrent infections with vector-borne pathogens associated with fatal hemolytic anemia in a cattle herd in Switzerland. J. Clin. Microbiol. 42, 3775-3780. doi: 10.1128/JCM.42.8.3775-3780.2004

Holden, K., Boothby, J. T., Anand, S., and Massung, R. F. (2003). Detection of Borrelia burgdorferi, Ehrlichia chaffeensis, and Anaplasma phagocytophilum in ticks (Acari: Ixodidae) from a coastal region of California. J. Med. Entomol. 40, 534-539. doi: 10.1603/0022-258540.4.534

Holden, K., Boothby, J. T., Kasten, R. W., and Chomel, B. B. (2006). Co-detection of Bartonella henselae, Borrelia burgdorferi, and Anaplasma phagocytophilum in Ixodes pacificus ticks from California, USA. Vector Borne Zoonotic Dis. 6, 99-102. doi: 10.1089/vbz.2006.6.99

Holman, M. S., Caporale, D. A., Goldberg, J., Lacombe, E., Lubelczyk, C., Rand, P. W., et al. (2004). Anaplasma phagocytophilum, Babesia microti, and Borrelia burgdorferi in Ixodes scapularis, southern coastal Maine. Emerg. Infect. Dis. 10, 744-746. doi: 10.3201/eid1004.030566

Hornok, S., Csörgö, T., de la Fuente, J., Gyuranecz, M., Privigyei, C., Meli, M. L., et al. (2013). Synanthropic birds associated with high prevalence of tick-borne rickettsiae and with the first detection of Rickettsia aeschlimannii in Hungary. Vector Borne Zoonotic Dis. 13, 77-83. doi: 10.1089/vbz.2012.1032

Horowitz, H. W., Kilchevsky, E., Haber, S., Aguero-Rosenfeldt, M., Kranwinkel, R., James, E. K., et al. (1998). Perinatal transmission of the agent of human granulocytic ehrlichiosis. $N$. Engl. J. Med. 339, 375-378. doi: 10.1056/NEJM199808063390604

Hotopp, J. C. D., Lin, M. Q., Madupu, R., Crabtree, J., Angiuoli, S. V., Eisen, J., et al. (2006).
Comparative Genomics of emerging human ehrlichiosis agents. PLoS Genet. 2:e21. doi: 10.1371/journal.pgen.0020021

Hulínská, D., Langøová, K., Pejèoch, M., and Pavlásek, I. (2004). Detection of Anaplasma phagocytophilum in animals by real-time polymerase chain reaction. APMIS 112, 239-247. doi: 10.1111/j.16000463.2004.apm11204-0503.x

Ijdo, J. W., Sun, W., Zhang, Y., Magnarelli, L. A., and Fikrig, E. (1998). Cloning of the gene encoding the 44-kilodalton antigen of the agent of human granulocytic ehrlichiosis and characterization of the humoral response. Infect. Immun. 66, 3264-3269.

Jaenson, T. G., Jaenson, D. G., Eisen, L., Petersson, E., and Lindgren, E. (2012). Changes in the geographical distribution and abundance of the tick Ixodes ricinus during the past 30 years in Sweden. Parasit. Vectors 5:8. doi: 10.1186/1756-3305-5-8

Jenkins, A., Kristiansen, B. E., Allum, A. G., Aakre, R. K., Strand, L., Kleveland, E. J., et al. (2001). Borrelia burgdorferi sensu lato and Ehrlichia spp. in Ixodes ticks from southern Norway. J. Clin. Microbiol. 39, 3666-3671. doi: 10.1128/JCM.39.10.3666-3671.2001

Jensen, J., Simon, D., Murua Escobar, H., Soller, J. T., Bullerdiek, J., Beelitz, P., et al. (2007). Anaplasma phagocytophilum in dogs in Germany. Zoonoses Public Health 54, 94-101. doi: 10.1111/j.1863-2378.2007.01028.x

Jensen, P. M., Hansen, H., and Frandsen, F. (2000). Spatial risk assessment for Lyme borreliosis in Denmark. Scand. J. Infect. Dis. 32, 545-550. doi: 10.1080/003655400458857

Jilintai, Seino, N., Hayakawa, D., Suzuki, M., Hata, H., Kondo, S. et al. (2009). Molecular survey for Anaplasma bovis and Anaplasma phagocytophilum infection in cattle in a pastureland where sika deer appear in Hokkaido, Japan. Jpn. J. Infect. Dis. 62, 73-75.

Johnson, R. C., Kodner, C., Jarnefeld, J., Eck, D. K., and Xu, Y. (2011). Agents of human anaplasmosis and Lyme disease at Camp Ripley, Minnesota. Vector Borne Zoonotic Dis. 11, 1529-1534. doi: $10.1089 /$ vbz.2011.0633

Johnston, E., Tsao, J. I., Muñoz, J. D., and Owen, J. (2013). Anaplasma phagocytophilum infection in American robins and gray catbirds: an assessment of reservoir competence and disease in captive wildlife. J. Med. Entomol. 50, 163-170.
Jordan, R. A., Schulze, T. L., and Jahn, M. B. (2007). Effects of reduced deer density on the abundance of Ixodes scapularis (Acari: Ixodidae) and Lyme disease incidence in a northern New Jersey endemic area. J. Med. Entomol. 44, 752-757. doi: 10.1603/0022 258544[752:EORDDO]2.0.CO;2

Jore, S., Viljugrein, H., Hofshagen, M. Brun-Hansen, H., Kristoffersen, A. B., Nygård, K., et al. (2011). Multisource analysis reveals latitudinal and altitudinal shifts in range of Ixodes ricinus at its northern distribution limit. Parasit. Vectors 4:84 doi: 10.1186/1756-3305-4-84

Kahl, O., Gern, L., Eisen, L., and Lane, R. S. (2002). "Ecological research on Borrelia burgdorferi sensu lato: terminology and some methodological pitfalls, " in Lyme borreliosis Biology, Epidemiology and Control, eds J. S. Gray, O. Kahl, R. S. Lane, and G. Stanek (Oxon: CABI Publishing), 29-46. doi: 10.1079/9780851996325.0029

Kahlon, A., Ojogun, N., Ragland, S. A. Seidman, D., Troese, M. J., Ottens, A. K., et al. (2013). Anaplasma phagocytophilum Asp14 is an invasin that interacts with mammalian host cells via its $\mathrm{C}$ terminus to facilitate infection. Infect. Immun. 81, 65-79. doi: 10.1128/IAI.00932-12

Kang, J. G., Kim, H. C., Choi, C. Y. Nam, H. Y., Chae, H. Y., Chong, S. T., et al. (2013). Molecular detection of Anaplasma, Bartonella, and Borrelia species in ticks collected from migratory birds from Hongdo Island, Republic of Korea. Vector Borne Zoonotic Dis. 13, 215-225. doi: 10.1089/vbz.2012.1149

Kang, J. G., Ko, S., Kim, Y. J., Yang, H. J., Lee, H., Shin, N. S., et al (2011). New genetic variants of Anaplasma phagocytophilum and Anaplasma bovis from Korean water deer (Hydropotes inermis argyropus). Vector Borne Zoonotic Dis. 11, 929-938. doi $10.1089 / v b z .2010 .0214$

Karbowiak, G., Vichova, B. Majlathova, V., Hapunik, J., and Petko, B. (2009). Anaplasma phagocytophilum infection of red foxes (Vulpes vulpes). Ann. Agric. Environ. Med. 16, 299-300.

Katargina, O., Geller, J., Alekseev, A., Dubinina, H., Efremova, G., Mishaeva, N., et al. (2012). Identification of Anaplasma phagocytophilum in tick populations in Estonia, the European part of Russia and Belarus. Clin Microbiol. Infect. 18, 40-46. doi: 10.1111/j.1469-0691.2010.03457.x
Kawahara, M., Rikihisa, Y., Lin, Q., Isogai, E., Tahara, K., Itagaki, A. et al. (2006). Novel genetic variants of Anaplasma phagocytophilum, Anaplasma bovis, Anaplasma centrale, and a novel Ehrlichia sp. in wild deer and ticks on two major islands in Japan. Appl. Environ. Microbiol. 72, 1102-1109. doi: 10.1128/AEM.72.2.1102-1109.2006

Kiffner, C., Vor, T., Hagedorn, P., Niedrig, M., and Rühe, F. (2011). Factors affecting patterns of tick parasitism on forest rodents in tick-borne encephalitis risk areas, Germany. Parasitol. Res. 108, 323-335. doi: 10.1007/s00436-010-2065-x

Kiilerich, A. M., Christensen, H., and Thamsborg, S. M. (2009). Anaplasma phagocytophilum in Danish sheep: confirmation by DNA sequencing. Acta Vet. Scand. 51:55. doi: 10.1186/1751-0147-51-55

Kim, C. M., Yi, Y. H., Yu, D. H., Lee, M. J., Cho, M. R., Desai, A. R., et al. (2006). Tick-borne rickettsial pathogens in ticks and small mammals in Korea. Appl. Environ. Microbiol. 72, 5766-5776. doi: 10.1128/AEM.00431-06

Klein, M. B., Miller, J. S., Nelson, C. M., and Goodman, J. L. (1997). Primary bone marrow progenitors of both granulocytic and monocytic lineages are susceptible to infection with the agent of human granulocytic ehrlichiosis. J. Infect. Dis. 176, 1405-1409. doi: 10.1086/517332

Koèi, J., Movila, A., Taragel'ová, V., Toderas, I., Uspenskaia, I., Derdáková, M., et al. (2007). First report of Anaplasma phagocytophilum and its co-infections with Borrelia burgdorferi sensu lato in Ixodes ricinus ticks (Acari: Ixodidae) from Republic of Moldova. Exp. Appl. Acarol. 41, 147-152. doi: 10.1007/s10493-007-9048-3

Kohn, B., Silaghi, C., Galke, D. Arndt, G., and Pfister, K. (2011). Infections with Anaplasma phagocytophilum in dogs in Germany. Res. Vet. Sci. 91, 71-76. doi: 10.1016/j.rvsc.2010.08.008

Kramer, V. L., Randolph, M. P., Hui, L. T., Irwin, W. E., Gutierrez, A. G., and Vugia, D. J. (1999). Detection of the agents of human ehrlichioses in ixodid ticks from California Am. J. Trop. Med. Hyg. 60, 62-65.

Kybicová, K., Schánilec, P., Hulínská, D., Uherková, L., Kurzová, Z., and Spejchalová, S. (2009). Detection of Anaplasma phagocytophilum and Borrelia burgdorferi sensu lato in dogs in the Czech Republic. Vector 
Borne Zoonotic Dis. 9, 655-661. doi: 10.1089/vbz.2008.0127

Labuda, M., Trimnell, A. R., Licková, M., Kazimírová, M., Davies, G. M., Lissina, O., et al. (2006). An antivector vaccine protects against a lethal vector-borne pathogen. PLoS Pathog. 2:e27. doi: 10.1371/journal.ppat.0020027

Ladbury, G. A. F., Stuen, S., Thomas, R., Bown, K. J., Woldehiwet, Z., Granquist, E. G., et al. (2008). Dynamic transmission of numerous Anaplasma phagocytophilum genotypes among lambs in an infected sheep flock in an area of anaplasmosis endemicity. J. Clin. Microbiol. 46, 1686-1691. doi: 10.1128/JCM.02068-07

Laloy, E., Petit, E., Boulouis, H. J., Gandoin, C., Bouillin, C., Gounot, G., et al. (2009). Dynamics of natural infection by Anaplasma phagocytophilum in a dairy cattle herd in Brittany, France. Clin. Microbiol. Infect. 15(Suppl. 2), 24-25. doi: 10.1111/j.1469-0691.2008.02142.x

Lane, R. S., Foley, J. E., Eisen, L., Lennette, E. T., and Peot, M. A. (2001). Acarologic risk of exposure to emerging tick-borne bacterial pathogens in a semirural community in northern California. Vector Borne Zoonotic Dis. 1, 197-210. doi: 10.1089/153036601753552567

Lane, R. S., Mun, J., Peribáñez, M. A., and Fedorova, N. (2010). Differences in prevalence of Borrelia burgdorferi and Anaplasma spp. infection among host-seeking Dermacentor occidentalis, Ixodes pacificus, and Ornithodoros coriaceus ticks in northwestern California. Ticks Tick Borne Dis. 1, 159-167.

Lane, R. S., Steinlein, D. B., and Mun, J. (2004). Human behaviors elevating exposure to Ixodes pacificus (Acari: Ixodidae) nymphs and their associated bacterial zoonotic agents in a hardwood forest. J. Med. Entomol. 41, 239-248. doi: 10.1603/00222585-412.239

Larson, L.-G., Aspan, A., and Bergström, K. (2006). Persistence of Anaplasma phagocytophilum in naturally infected Swedish cattle. (in Swedish). Svensk Vet. Tidn. 58, 13-19.

Lascola, K., Vandis, M., Bain, P., and Bedenice, D. (2009). Concurrent Infection with Anaplasma phagocytophilum and Mycoplasma haemolamae in a young alpaca. J. Vet. Intern. Med. 23, 379-382. doi: 10.1111/j.1939-1676.2008.0268.x

Laus, F., Veronesi, F., Passamonti, F., Paggi, E., Cerquetella, M., Hyatt, D., et al. (2013). Prevalence of tick borne pathogens in horses from
Italy. J. Vet. Med. Sci. 75, 715-720. doi: 10.1292/jvms.12-0449

Lee, H. C., and Goodman, J. L. (2006). Anaplasma phagocytophilum causes global induction of antiapoptosis in human neutrophils. Genomics 88, 496-503. doi: 10.1016/j.ygeno.2006.06.002

Lempereur, L., Lebrun, M., Cuvelier, P., Sepult, G., Caron, Y., Saegerman, C., et al. (2012). Longitudinal field study on bovine Babesia spp. and Anaplasma phagocytophilum infections during a grazing season in Belgium. Parasitol. Res. 110, 1525-1530. doi: 10.1007/s00436-011-2657-0

Lepidi, H., Bunnell, J. E., Martin, M. E., Madigan, J. E., Stuen, S., and Dumler, J. S. (2000). Comparative pathology and immunohistology associated with clinical illness after Ehrlichia phagocytophila-group infections. Am. J. Trop. Med. Hyg. 62, 29-37.

Leschnik, M., Kirtz, G., Virányi, Z., Wille-Piazzai, W., and Duscher, G. (2012). Acute granulocytic anaplasmosis in a captive timber wolf (Canis lupus occidentalis). J. Zoo. Wildl. Med. 43, 645-648. doi: 10.1638/2011-0224R.1

Leutenegger, C. M., Pusterla, N., Mislin, C. N., Weber, R., and Lutz, H. (1999). Molecular evidence of coinfection of ticks with Borrelia burgdorferi sensu lato and the human granulocytic ehrlichiosis agent in Switzerland. J. Clin. Microbiol. 37, 3390-3391.

Levin, M. L., des Vignes, F., and Fish, D. (1999). Disparity in the natural cycles of Borrelia burgdorferi and the agent of human granulocytic ehrlichiosis. Emerg. Infect. Dis. 5, 204-208. doi: 10.3201/eid0502.990203

Levin, M. L., Nicholson, W. L., Massung, R. F., Sumner, J. W., and Fish, D. (2002). Comparison of the reservoir competence of mediumsized mammals and Peromyscus leucopus for Anaplasma phagocytophilum in Connecticut. Vector Borne Zoonotic Dis. 2, 125-136. doi: 10.1089/15303660260613693

Li, H., Zhou, Y., Wang, W., Guo, D., Huang, S., and Jie, S. (2011) The clinical characteristics and outcomes of patients with human granulocytic anaplasmosis in China. Int. J. Infect. Dis. 15, 859-866. doi: 10.1016/j.ijid.2011. 09.008

Lillini, E., Macri, G., Proietti, G., and Scarpulla, M. (2006). New findings on anaplasmosis caused by infection with Anaplasma phagocytophilum.
Ann. N.Y. Acad. Sci. 1081, 360-370. doi: 10.1196/annals.1373.053

Lin, M., Kikuchi, T., Brewer, H M., Norbeck, A. D., Rikihisa, Y. (2011). Global proteomic analysis of two tick-borne emerging zoonotic agents: Anaplasma phagocytophilum and Ehrlichia chaffeensis. Front. Microbiol. 2:24. doi: 10.3389/fmicb.2011.00024

Lin, M. Q., and Rikihisa, Y. (2003a). Ehrlichia chaffeensis and Anaplasma phagocytophilum lack genes for lipid a biosynthesis and incorporate cholesterol for their survival. Infect. Immun. 71, 5324-5331. doi: 10.1128/IAI.71.9.5324-5331.2003

Lin, M. Q., and Rikihisa, Y. (2003b). Obligatory intracellular parasitism by Ehrlichia chaffeensis and Anaplasma phagocytophilum involves caveolae and glycosylphosphatidylinositol-

anchored proteins. Cell. Microbiol. 5, 809-820. doi: 10.1046/j.1462-5822.2003.00322.x

Lin, Q., Rikihisa, Y., Ohashi, N., and Zhi, N. (2003). Mechanisms of variable p44 expression by Anaplasma phagocytophilum. Infect. Immun. 71, 5650-5661. doi: 10.1128/IAI.71.10.5650-5661.2003

Liu, Z., Ma, M., Wang, Z., Wang, J., Peng, Y., Li, Y., et al. (2012). Molecular survey and genetic identification of Anaplasma species in goats from central and southern China. Appl. Environ. Microbiol. 78, 464-470. doi: 10.1128/AEM.0684811

Liz, J. S., Anderes, L., Sumner, J. W., Massung, R. F., Gern, L., Rutti, B., et al. (2000). PCR detection of granulocytic ehrlichiae in Ixodes ricinus ticks and wild small mammals in western Switzerland. J. Clin. Microbiol. 38, 1002-1007.

Liz, J. S., Sumner, J. W., Pfister K., and Brossard, M. (2002). PCR detection and serological evidence of granulocytic ehrlichial infection in roe deer (Capreolus capreolus) and chamois (Rupicapra rupicapra). J. Clin. Microbiol. 40, 892-897. doi: 10.1128/JCM.40.3.892-897.2002

Lommano, E., Bertaiola, L., Dupasquier, C., and Gern, L. (2012). Infections and co-infections of questing Ixodes ricinus ticks by emerging zoonotic pathogens in Western Switzerland. Appl. Environ. Microbiol. 78, 4606-4612. doi: 10.1128/AEM.07961-11

Lovrich, S. D., Jobe, D. A., Kowalski, T. J., Policepatil, S. M., and Callister, S. M. (2011). Expansion of the Midwestern focus for human granulocytic anaplasmosis into the region surrounding La Crosse, Wisconsin. J. Clin. Microbiol. 49, 3855-3859. doi: 10.1128/JCM.05025-11

Maeda, K., Markowitz, N., Hawley, R. C., Ristic, M., Cox, D., and McDade, J. E. (1987). Human infection with Ehrlichia canis, a leucocytic rickettsia. N. Engl. J. Med. 316, 853-856. doi: 10.1056/NEJM198704023161406

Magnarelli, L. A., Ijdo, J. W., Shermant, B. A., Bushmich, S. L., Levy, S. A., and Fikrig, E. (2002). Antibodies to granulocytic ehrlichiae in cattle from Connecticut. J. Med. Microbiol. 51, 326-331.

Magnarelli, L. A., Ijdo, J. W., Stafford, K. C. 3rd., and Fikrig, E. (1999). Infections of granulocytic ehrlichiae and Borrelia burgdorferi in whitetailed deer in Connecticut. J. Wildl. Dis. 35, 266-274.

Magnarelli, L. A., Ijdo, J. W., Van Andel, A. E., Wu, C., and Fikrig, E. (2001). Evaluation of a polyvalent enzyme-linked immunosorbent assay incorporating a recombinant p44 antigen for diagnosis of granulocytic ehrlichiosis in dogs and horses. Am. J. Vet. Res. 62, 29-32. doi: 10.2460/ajvr.2001.62.29

Magnarelli, L. A., Stafford, K. C. 3rd., Mather, T. N., Yeh, M. T., Horn, K. D., and Dumler, J. S. (1995). Hemocytic rickettsia-like organisms in ticks: serologic reactivity with antisera to Ehrlichiae and detection of DNA of agent of human granulocytic ehrlichiosis by PCR. J. Clin. Microbiol. 33, 2710-2714.

Mäkinen, J., Vuorinen, I., Oksi, J., Peltomaa, M., He, Q., Marjamäki, M., et al. (2003). Prevalence of granulocytic Ehrlichia and Borrelia burgdorferi sensu lato in Ixodes ricinus ticks collected from Southwestern Finland and from Vormsi Island in Estonia. APMIS 111, 355-362. doi: 10.1034/j.16000463.2003.1110209.x

Mantelli, B., Pecchioli, E., Hauffe, H. C., Rosa, R., and Rizzoli, A. (2006) Prevalence of Borrelia burgdorferi s.l. and Anaplasma phagocytophilum in the wood tick Ixodes ricinus in the Province of Trento, Italy. Eur. J. Clin. Microbiol. Infect. Dis. 25, 737-739. doi: 10.1007/s10096-006-0208-x

Massung, R. F., Courtney, J. W., Hiratzka, S. L., Pitzer, V. E., Smith, G., and Dryden, R. L. (2005). Anaplasma phagocytophilum in white-tailed deer. Emerg. Infect. Dis. 11, 1604-1606. doi: 10.3201/eid1110.041329

Massung, R. F., Lee, K., Mauel, M., and Gusa, A. (2002). Characterization of the rRNA genes of Ehrlichia chaffeensis 
and Anaplasma phagocytophila. DNA Cell Biol. 21, 587-596. doi: 10.1089/104454902320308960

Massung, R. F., Levin, M. L., Munderloh, U. G., Silverman, D. J., Lynch, M. J., Gaywee, J. K., et al. (2007). Isolation and propagation of the Ap-Variant 1 Strain of Anaplasma phagocytophilum in a tick cell line. J. Clin. Microbiol. 45, 2138-2143.

Massung, R. F., Mather, T. N., and Levin, M. L. (2006). Reservoir competency of goats for the Ap-variant 1 strain of Anaplasma phagocytophilum. Infect. Immun. 74, 1373-1375. doi: 10.1128/IAI.74.2.1373-1375.2006

Massung, R. F., Mauel, M. J., Owens, J. H., Allan, N., Courtney, J. W., Stafford, K. C. 3rd., et al. (2002). Genetic variants of Ehrlichia phagocytophila, Rhode Island and Connecticut. Emerg. Infect. Dis. 8, 467-472. doi: 10.3201/eid0805. 010251

Massung, R. F., Owens, J. H., Ross, D., Reed, K. D., Petrovec, M., Bjoersdorff, A., et al. (2000). Sequence analysis of the ank gene of granulocytic ehrlichiae. J. Clin. Microbiol. 38, 2917-2922.

Massung, R. F., Priestley, R. A., Miller, N. J., Mather, T. N., and Levin, M. L. (2003). Inability of a variant strain of Anaplasma phagocytophilum to infect mice. J. Infect. Dis. 188, 1757-1763. doi: 10.1086/379725

Mastronunzio, J. E., Kurscheid, S., and Fikrig, E. (2012). Postgenomic analyses reveal development of infectious Anaplasma phagocytophilum during transmission from ticks to mice. J. Bacteriol. 194, 2238-2247. doi: 10.1128/JB.06791-11

Masuzawa, T., Kharitonenkov, I. G., Okamoto, Y., Fukui, T., and Ohashi, N. (2008). Prevalence of Anaplasma phagocytophilum and its coinfection with Borrelia afzelii in Ixodes ricinus and Ixodes persulcatus ticks inhabiting Tver Province (Russia) - a sympatric region for both tick species. J. Med. Microbiol. 57, 986-991. doi: 10.1099/jmm.0. 47721-0

Masuzawa, T., Uchishima, Y., Fukui, T., Okamoto, Y., Muto, M., Koizumi, N., et al. (2011). Detection of Anaplasma phagocytophilum from wild boars and deer in Japan. Jpn. J. Infect. Dis. 64, 333-336.

Materna, J., Daniel, M., and Danielová, V. (2005). Altitudinal distribution limit of the tick Ixodes ricinus shifted considerably towards higher altitudes in central Europe: results of three years monitoring in the Krkonose Mts. (Czech Republic).
Cent. Eur. J. Public Health. 13, 24-28.

Matsumoto, K., Grzeszczuk, A., Brouqui, P., and Raoult, D. (2009). Rickettsia raoultii and Anaplasma phagocytophilum in Dermacentor reticulatus ticks collected from Bialowieza Primeval Forest European bison (Bison bonasus bonasus), Poland. Clin. Microbiol. Infect. 15(Suppl. 2), 286-287. doi: 10.1111/j.1469-0691.2008.02238.x

Matsumoto, K., Joncour, G., Lamanda, P., Inokuma, H., and Brouqui, P. (2007). Detection of Anaplasma phagocytophilum and Ehrlichia sp. HF strains in Ixodes ricinus ticks in Brittany, France. Clin. Microbiol. Infect. 13, 338-341. doi: 10.1111/j.1469-0691.2006.01630.x

Medlock, J. M., Hansford, K. M., Bormane, A., Derdakova, M., Estrada-Peña, A., George, J. C., et al. (2013). Driving forces for changes in geographical distribution of Ixodes ricinus ticks in Europe. Parasit. Vectors 6:1. doi: 10.1186/ 1756-3305-6-1

M'Ghirbi, Y., Ghorbel, A., Amouri, M., Nebaoui, A., Haddad, S., and Bouattour, A. (2009). Clinical, serological, and molecular evidence of ehrlichiosis and anaplasmosis in dogs in Tunisia. Parasitol. Res. 104, 767-774. doi: 10.1007/s00436-0081253-4

M'Ghirbi, Y., Yaich, H., Ghorbel, A., and Bouattour, A. (2012). Anaplasma phagocytophilum in horses and ticks in Tunisia. Parasit. Vectors 5:180. doi: 10.1186/17563305-5-180

Michalik, J., Stanczak, J., Cieniuch, S., Racewicz, M., Sikora, B., and Dabert, M. (2012). Wild boars as hosts of human-pathogenic Anaplasma phagocytophilum variants. Emerg. Infect. Dis. 18, 998-1001. doi: 10.3201/eid1806. 110997

Michalik, J., Stanczak, J., Racewicz, M., Cieniuch, S., Sikora, B., Szubert-Kruszynska, A., et al. (2009). Molecular evidence of Anaplasma phagocytophilum infection in wild cervids and feeding Ixodes ricinus ticks from westcentral Poland. Clin. Microbiol. Infect. 15(Suppl. 2), 81-83. doi: 10.1111/j.1469-0691.2008.02240.x

Michalski, M., Rosenfield, C., Erickson, M., Selle, R., Bates, K., Essar, D., et al. (2006). Anaplasma phagocytophilum in central and western Wisconsin: a molecular survey. Parasitol. Res. 99, 694-699. doi: 10.1007/s00436-006-0217-9

Moreno, C. X., Moy, F., Daniels, T. J., Godfrey, H. P., and Cabello,
F. C. (2006). Molecular analysis of microbial communities identified in different developmental stages of Ixodes scapularis ticks from Westchester and Dutchess Counties, New York. Environ. Microbiol. 8, 761-772. doi: 10.1111/j.1462-2920.2005.00955.x

Morgenthal, D., Hamel, D., Arndt, G., Silaghi, C., Pfister, K., Kempf, V. A., et al. (2012). Prevalence of haemotropic Mycoplasma spp., Bartonella spp. and Anaplasma phagocytophilum in cats in Berlin/Brandenburg (Northeast Germany). Berl. Munch. Tierarztl. Wochenschr. 125, 418-427.

Movila, A., Rolain, J. M., Podavalenko, A., Toderas, I., Tkachenco, L., Naglov, V., et al. (2009). Detection of spotted fever group rickettsiae and family Anaplasmataceae in Ixodes ricinus ticks from Republic of Moldova and Eastern Ukraine. Clin. Microbiol. Infect. 15(Suppl. 2), 32-33. doi: 10.1111/j.1469-0691.2008.02152.x

Munderloh, U. G., Jauron, S. D., Fingerle, V., Leitritz, L., Hayes, S. F., Hautman, J. M., et al. (1999). Invasion and intracellular development of the human granulocytic ehrlichiosis agent in tick cell culture. J. Clin. Microbiol. 37, 2518-2524.

Munderloh, U. G., Lynch, M. J., Herron, M. J., Palmer, A. T., Kurtti, T. J., Nelson, R. D., et al. (2004). Infection of endothelial cells with Anaplasma marginale and A. phagocytophilum. Vet. Microbiol. 101, 53-64. doi: 10.1016/j.vetmic.2004.02.011

Munderloh, U. G., Madigan, J. E., Dumler, J. S., Goodman, J. L., Hayes, S. F., Barlough, J. E., et al. (1996). Isolation of the equine granulocytic ehrlichiosis agent, Ehrlichia equi, in tick cell culture. J. Clin. Microbiol. 34, 664-670.

Munro, R., Hunter, A. R., MacKenzie, G., and McMartin, D. A. (1982). Pulmonary lesions in sheep following experimental infection by Ehrlichia phagocytophila and Chlamydia psittaci. J. Comp. Pathol. 92, 117-129. doi: 10.1016/0021-997590047-0

Murase, Y., Konnai, S., Hidano, A., Githaka, N. W., Ito, T., Takano, A., et al. (2011). Molecular detection of Anaplasma phagocytophilum in cattle and Ixodes persulcatus ticks. Vet. Microbiol. 149, 504-507. doi: 10.1016/j.vetmic.2010.11.025

Naranjo, V., Ruiz-Fons, F., Hofle, U., Fernandez De Mera, I. G., Villanua, D., Almazan, C., et al. (2006). Molecular epidemiology of human and bovine anaplasmosis in southern Europe. Ann. N.Y. Acad. Sci. 1078, 95-99. doi: 10.1196/annals.1374.013

Nicholson, W. L., Castro, M. B., Kramer, V. L., Sumner, J. W., and Childs, J. E. (1999). Dusky-footed wood rats (Neotoma fuscipes) as reservoirs of granulocytic Ehrlichiae (Rickettsiales: Ehrlichieae) in northern California. J. Clin. Microbiol. 37, 3323-3327.

Nieto, N. C., and Foley, J. E. (2008). Evaluation of squirrels (Rodentia: Sciuridae) as ecologically significant hosts for Anaplasma phagocytophilum in California. J. Med. Entomol. 45, 763-769. doi: 10.1603/0022258545[763:EOSRSA] 2.0.CO;2

Nieto, N. C., Foley, J. E., Bettaso, J., and Lane, R. S. (2009). Reptile infection with Anaplasma phagocytophilum, the causative agent of granulocytic anaplasmosis. J. Parasitol. 95, 1165-1170. doi: 10.1645/GE-1983.1

Nieto, N. C., Leonhard, S., Joley, J. E., and Lane, R. S. (2010). Coinfection of Western Gray Squirrel (Sciurus griseus) and other Sciurid rodents with Borrelia burgdorferi sensu strictu and Anaplasma phagocytophilum in California. J. Wildl. Dis. 46, 291-296

Oehme, R., Hartelt, K., Backe, H., Brockmann, S., and Kimmig, P. (2002). Foci of tick-borne diseases in southwest Germany. Int. J. Med. Microbiol. 291(Suppl. 33), 22-29. doi: 10.1016/S1438-422180005-4

Ogden, N. H., Bown, K., Horrocks, B. K., Woldehiwet, Z., and Bennett, M. (1998). Granulocytic Ehrlichia infection in ixodid ticks and mammals in woodlands and uplands of the U.K. Med. Vet. Entomol. 12, 423-429. doi: 10.1046/j.13652915.1998.00133.x

Ogden, N. H., Lindsay, L. R., Hanincová, K., Barker, I. K., Bigras-Poulin, M., Charron, D. F., et al. (2008). Role of migratory birds in introduction and range expansion of Ixodes scapularis ticks and of Borrelia burgdorferi and Anaplasma phagocytophilum in Canada. Appl. Environ. Microbiol. 74, 1780-1790. doi: 10.1128/AEM.01982-07

Ohashi, N., Inayoshi, M., Kitamura, K., Kawamori, F., Kawaguchi, D., Nishimura, Y., et al. (2005). Anaplasma phagocytophiluminfected ticks, Japan. Emerg. Infect. Dis. 11, 1780-1783. doi: 10.3201/eid1111.050407

Ojogun, N., Kahlon, A., Ragland, S. A., Troese, M. J., Mastronunzio, J. E., Walker, N. J., et al. (2012). Anaplasma phagocytophilum outer membrane protein A interacts with 
sialylated glycoproteins to promote infection of mammalian host cells. Infect. Immun. 80, 3748-3760. doi: 10.1128/IAI.00654-12

Ooshiro, M., Zakimi, S., Matsukawa, Y., Katagiri, Y., and Inokuma, H. (2008). Detection of Anaplasma bovis and Anaplasma phagocytophilum from cattle on Yonaguni Island, Okinawa, Japan. Vet. Parasitol. 154, 360-364. doi: 10.1016/j.vetpar.2008.03.028

Oporto, B., Gil, H., Barral, M., Hurtado, A., Juste, R. A., and García-Pérez, A. L. (2003). A survey on Anaplasma phagocytophila in wild small mammals and roe deer (Capreolus capreolus) in Northern Spain. Ann. N.Y. Acad. Sci. 990, 98-102. doi: 10.1111/j.17496632.2003.tb07344.x

Øverås, J., Lund, A., Ulvund, M. J., and Waldeland, H. (1993). Tick-borne fever as a possible predisposing factor in septicaemic pasteurellosis in lambs. Vet. Rec. 133, 398.

Overzier, E., Pfister, K., Herb, I., Mahling, M., Böck, G. Jr., and Silaghi, C. (2013a). Detection of tick-borne pathogens in roe deer (Capreolus capreolus), questing ticks (Ixodes ricinus) and ticks infesting roe deer in southern Germany. Ticks Tick Borne Dis. 4, 320-328. doi: 10.1016/j.ttbdis.2013.01.004

Overzier, E., Pfister, K., Thiel, C., Herb, I., Mahling, M., and Silaghi, C. (2013b). Anaplasma phagocytophilum in questing Ixodes ricinus Ticks: comparison of prevalences and partial 16S rRNA gene variants in urban, pasture, and natural habitats. Appl. Environ. Microbiol. 79, 1730-1734. doi: 10.1128/AEM.03300-12

Palomar, A. M., Santibáñez, P., Mazuelas, D., Roncero, L., Santibáñez, S., Portillo, A., et al. (2012). Role of birds in dispersal of etiologic agents of tick-borne zoonoses, Spain. Emerg. Infect. Dis. 18, 1188-1191.

Park, J., Choi, K. S., and Dumler, J. S. (2003). Major surface protein 2 of Anaplasma phagocytophilum facilitates adherence to granulocytes. Infect. Immun. 71, 4018-4025. doi: 10.1128/IAI.71.7.4018-4025.2003

Passamonti, F., Veronesi, F., Cappelli, K., Capomaccio, S., Coppola, G., Marenzoni, M. L., et al. (2010). Anaplasma phagocytophilum in horses and ticks: a preliminary survey of Central Italy. Comp. Immunol. Microbiol. Infect. Dis. 33, 73-83. doi: 10.1016/j.cimid.2008.08.002

Paulauskas, A., Radzijevskaja, J., and Rosef, O. (2012). Molecular detection and characterization of Anaplasma phagocytophilum strains. Comp. Immunol. Microbiol. Infect. Dis. 35, 187-195. doi: 10.1016/j.cimid.2012.01.001

Paxton, E. A., and Scott, G. R. (1989). Detection of antibodies to the agent of tick-borne fever by indirect immunofluorescence. Vet. Microbiol. 21, 133-138. doi: 10.1016/0378-113590025-4

Petrovec, M., Sumner, J. W., Nicholson, W. L., Childs, J. E., Strle, F., Barlic, J., et al. (1999). Identity of ehrlichial DNA sequences derived from Ixodes ricinus ticks with those obtained from patients with human granulocytic ehrlichiosis in Slovenia. J. Clin. Microbiol. 37, 209-210.

Philip, C. B. (1974) "Tribe, I. I. Ehrlichieae Philip 1957,” in Bergey's Manual of Determinative Bacteriology 8th Edn., eds R. E. Buchanan and N. E. Gibbons (Baltimore, MD: The Williams and Wilkins Company), 893-897.

Piccolin, G., Benedetti, G., Doglioni, C., Lorenzato, C., Mancuso, S., Papa, N., et al. (2006). A study of the presence of $B$. burgdorferi, Anaplasma (previously Ehrlichia) phagocytophilum, Rickettsia, and Babesia in Ixodes ricinus collected within the territory of Belluno, Italy. Vector Borne Zoonotic Dis. 6, 24-31. doi: 10.1089/vbz.2006.6.24

Pichon, B., Kahl, O., Hammer, B., and Gray, J. S. (2006). Pathogens and host DNA in Ixodes ricinus nymphal ticks from a German forest. Vector Borne Zoonotic Dis. 6, 382-387. doi: 10.1089/vbz.2006.6.382

Polin, H., Hufnagl, P., Haunschmid, R., Gruber, F., and Ladurner, G. (2004). Molecular evidence of Anaplasma phagocytophilum in Ixodes ricinus ticks and wild animals in Austria. J. Clin. Microbiol. 42, 2285-2286. doi: 10.1128/JCM.42.5.2285-2286.2004

Portillo, A., Pérez-Martínez, L., Santibáñez, S., Santibáñez, P., Palomar, A. M., and Oteo, J. A. (2011). Anaplasma spp. in wild mammals and Ixodes ricinus from the north of Spain. Vector Borne Zoonotic Dis. 11, 3-8.

Portillo, A., Santos, A. S., Santibanez, S., Pérez-Martinez, L., Blanco, J. R., Ibarra, V., et al. (2005). Detection of a non-pathogenic variant of Anaplasma phagocytophilum in Ixodes ricinus from La Rioja, Spain. Ann. N.Y. Acad. Sci. 1063, 333-336. doi: 10.1196/annals. 1355.053

Pusterla, N., Leutenegger, C. M., Huder, J. B., Weber, R., Braun, U., and Lutz, H. (1999). Evidence of the human granulocytic ehrlichiosis agent in
Ixodes ricinus ticks in Switzerland. J. Clin. Microbiol. 37, 1332-1334.

Radzijevskaja, J., Paulauskas, A., and Rosef, O. (2008). Prevalence of Anaplasma phagocytophilum and Babesia divergens in Ixodes ricinus from Lithuania and Norway. Int. J. Med. Microbiol. 298, 218-221. doi: 10.1016/j.ijmm.2008.01.008

Rand, P. W., Lubelczyk, C., Lavigne, G. R., Elias, S., Holman, M. S. Lacombe, E. H., et al. (2003). Deer density and the abundance of Ixodes scapularis (Acari: Ixodidae). J. Med. Entomol. 40, 179-184. doi: $\quad 10.1603 / 0022-2585-40$ 2.179

Rar, V. A., Epikhina, T. I., Livanova, N. N., Panov, V. V., Doroschenko, E. K., Pukhovskaya, N. M., et al. (2011). Genetic variability of Anaplasma phagocytophilum in Ixodes persulcatus ticks and small mammals in the Asian part of Russia. Vector Borne Zoonotic Dis. 11, 1013-1021. doi: 10.1089/vbz.2010.0266

Rar, V. A., Fomenko, N. V., Dobrotvorsky, A. K., Livanova, N. N., Rudakova, S. A., Fedorov, E. G., et al. (2005). Tickborne pathogen detection, Western Siberia, Russia. Emerg. Infect. Dis. 11, 1708-1715. doi: 10.3201/eid1111.041195

Ravyn, M. D., Goodman, J. L., Kodner, C. B., Westad, D. K., Coleman, L. A., Engstrom, S. M., et al. (1998). Immunodiagnosis of human granulocytic ehrlichiosis by using culture-derived human isolates. J. Clin. Microbiol. 36, 1480-1488.

Reichard, M. V., Roman, R. M., Kocan, K. M., Blouin, E. F., de la Fuente, J., Snider, T. A., et al. (2009). Inoculation of white-tailed deer (Odocoileus virginianus) with Ap$\mathrm{V}$ or NY-18 strains of Anaplasma phagocytophilum and microscopic demonstration of Ap-V1 in Ixodes scapularis adults that acquired infection from deer as nymphs. Vector Borne Zoonotic Dis. 9, 565-568. doi: 10.1089/vbz.2008.0106

Reis, C., Cote, M., Paul, R. E., and Bonnet, S. (2011). Questing ticks in suburban forest are infected by at least six tickborne pathogens. Vector Borne Zoonotic Dis. 11, 907-916. doi: 10.1089/vbz.2010.0103

Rejmanek, D., Foley, P., Barbet, A., and Foley, J. (2012). Evolution of antigen variation in the tick-borne pathogen Anaplasma phagocytophilum. Mol. Biol. Evol. 29, 391-400. doi: $10.1093 / \mathrm{molbev} / \mathrm{msr} 229$

Rejmanek, D., Nieto, N. C., Barash, N., and Foley, J. E. (2011). Temporal patterns of tick-borne granulocytic anaplasmosis in California. Ticks Tick Borne Dis. 2, 81-87. doi: 10.1016/j.ttbdis.2010.12.003

Reneer, D. V., Kearns, S. A., Yago, T., Sims, J., Cummings, R. D., McEver, R. P., et al. (2006). Characterization of a sialic acidand P-selectin glycoprotein ligand1-independent adhesin activity in the granulocytotropic bacterium Anaplasma phagocytophilum. Cell. Microbiol. 8, 1972-1984. doi: 10.1111/j.1462-5822.2006.00764.x

Reneer, D. V., Troese, M. J., Huang, B., Kearns, S. A., and Carlyon, J. A. (2008). Anaplasma phagocytophilum PSGL-1-independent infection does not require Syk and leads to less efficient AnkA delivery. Cell. Microbiol. 10, 1827-1838. doi: 10.1111/j.14625822.2008.01168.x

Reye, A. L., Hübschen, J. M., Sausy, A., and Müller, C. P. (2010). Prevalence and seasonality of tick-borne pathogens in questing Ixodes ricinus ticks from Luxembourg. Appl. Environ. Microbiol. 76, 2923-2931. doi: 10.1128/AEM.03061-09

Reye, A. L., Stegniy, V., Mishaeva, N. P., Velhin, S., Hübschen, J. M., Ignatyev, G., et al. (2013). Prevalence of tick-borne pathogens in Ixodes ricinus and Dermacentor reticulatus ticks from different geographical locations in Belarus. PLoS ONE 8:e54476. doi: 10.1371/journal.pone.0054476

Richter, D., and Matuschka, F. R. (2012). "Candidatus Neoehrlichia mikurensis, " Anaplasma phagocytophilum, and lyme disease spirochetes in questing european vector ticks and in feeding ticks removed from people. J. Clin. Microbiol. 50, 943-947. doi: 10.1128/JCM. 05802-11

Rikihisa, Y. (1991). The tribe Ehrlichieae and ehrlichial diseases. Clin. Microbiol. Rev. 4, 286-308.

Rikihisa, Y. (2003). Mechanisms to create a safe haven by members of the family Anaplasmataceae. Ann. N.Y. Acad. Sci. 990, 548-555.

Rikihisa, Y. (2011). Mechanisms of obligatory intracellular infection with Anaplasma phagocytophilum. Clin. Microbiol. Rev. 24, 469-489. doi: 10.1128/CMR.00064-10

Rizzoli, A., Hauffe, H. C., Tagliapietra, V., Neteler, M., and Rosà, R. (2009). Forest structure and roe deer abundance predict tick-borne encephalitis risk in Italy. PLoS ONE 4:e4336. doi: 10.1371/journal.pone.0004336

Robinson, M. T., Shaw, S. E., and Morgan, E. R. (2009). Anaplasma phagocytophilum infection in a multi-species deer community 
in the New Forest, England. Eur. J. Wildl. Res. 55, 439-442. doi: 10.1007/s10344-009-0261-8

Rodriguez, J. L., Palmer, G. H., Knowles, D. P., and Brayton, K. A. (2005). Distinctly different msp2 pseudogene repertoires in Anaplasma marginale strains that are capable of superinfection. Gene 361, 127-132. doi: 10.1016/j.gene.2005.06.038

Roellig, D. M., and Fang, Q. Q. (2012). Detection of Anaplasma phagocytophilum in ixodid ticks from equine-inhabited sites in the Southeastern United States. Vector Borne Zoonotic Dis. 12, 330-332. doi: 10.1089/vbz.2011.0757

Rosef, O., Paulauskas, A., and Radzijevskaja, J. (2009). Prevalence of Borrelia burgdorferi sensu lato and Anaplasma phagocytophilum in questing Ixodes ricinus ticks in relation to the density of wild cervids. Acta Vet. Scand. 51:47. doi: 10.1186/1751-0147-51-47

Ruiz-Fons, F., Fernández-de-Mera, I. G., Acevedo, P., Gortázar, C., and de la Fuente, J. (2012). Factors driving the abundance of Ixodes ricinus Ticks and the prevalence of zoonotic, I. ricinus-borne pathogens in natural foci. Appl. Environ. Microbiol. 78, 2669-2676. doi: 10.1128/AEM.06564-11

Rymaszewska, A. (2005). Identification of Anaplasma phagocytophilum on the basis of a fragment of the 16S rDNA gene. Folia Biol. (Krakow) 53, 199-203. doi: 10.3409/173491605775142765

Rymaszewska, A. (2008). Divergence within the marker region of the groESL operon in Anaplasma phagocytophilum. Eur. J. Clin. Microbiol. Infect. Dis. 27, 1025-1036. doi: 10.1007/s10096-008-0539-x

Rymaszewska, A., and Adamska, M. (2011). Molecular evidence of vector-borne pathogens coinfecting dogs from Poland. Acta Vet. Hung. 59, 215-223. doi: 10.1556/AVet.2011.008

Samish, M., Ginsberg, H., and Glazer, I. (2004). Biological control of ticks. Parasitology 129, S389-S403. doi: 10.1017/S0031182004005219

Santos, A. S., Santos-Silva, M. M., Almeida, V. C., Bacellar, F., and Dumler, J. S. (2004). Detection of Anaplasma phagocytophilum DNA in Ixodes ticks (Acari: Ixodidae) from Madeira island and Setubal district, mainland Portugal. Emerg. Infect. Dis. 10, 1643-1648. doi: 10.3201/eid1009.040276

Santos, H. A., Pires, M. S., Vilela, J. A. R., Santos, T. M., Faccini, J. L. H., Baldani, C. D., et al. (2011).
Detection of Anaplasma phagocytophilum in Brazilian dogs by realtime polymerase chain reaction. J. Vet. Diagn. Invest. 23, 770. doi: 10.1177/1040638711406974

Sarkar, A., Hellberg, L., Bhattacharyya, A., Behnen, M., Wang, K. Q., Lord J. M., et al. (2012). Infection with Anaplasma phagocytophilum activates the phosphatidylinositol 3kinase/Akt and NF-kappa B survival pathways in neutrophil granulocytes. Infect. Immun. 80, 1615-1623. doi: 10.1128/IAI.05219-11

Scharf, W., Schauer, S., Freyburger, F., Petrovec, M., SchaarschmidtKiener, D., Liebisch, G., et al. (2011). Distinct host species correlate with Anaplasma phagocytophilum ankA gene clusters. J. Clin. Microbiol. 49, 790-796. doi: 10.1128/JCM.0205110

Schicht, S., Junge, S., Schnieder, T., and Strube, C. (2011). Prevalence of Anaplasma phagocytophilum and coinfection with Borrelia burgdorferi Sensu Lato in the hard tick Ixodes ricinus in the City of Hanover (Germany). Vector Borne Zoonotic Dis. 11, 1595-1597. doi: 10.1089/vbz.2011.0699

Schorn, S., Pfister, K., Reulen, H., Mahling, M., Manitz, J., Thiel, C., et al. (2011). Prevalence of Anaplasma phagocytophilum in Ixodes ricinus in Bavarian public parks, Germany. Ticks Tick Borne Dis. 2, 196-203. doi: 10.1016/j.ttbdis.2011.09.009

Scorpio, D. G., Akkoyunlu, M., Fikrig, E., and Dumler, J. S. (2004). CXCR2 blockade influences Anaplasma phagocytophilum propagation but not histopathology in the mouse model of human granulocytic anaplasmosis. Clin. Diag. Lab. Immun. 11, 963-968.

Sen, E., Uchishima, Y., Okamoto, Y., Fukui, T., Kadosaka, T., Ohashi, N., et al. (2011). Molecular detection of Anaplasma phagocytophilum and Borrelia burgdorferi in Ixodes ricinus ticks from Istanbul metropolitan area and rural Trakya (Thrace) region of north-western Turkey. Ticks Tick Borne Dis. 2, 94-98. doi: 10.1016/j.ttbdis.2011.03.004

Severinsson, K., Jaenson, T. G., Pettersson, J., Falk, K., and Nilsson, K. (2010). Detection and prevalence of Anaplasma phagocytophilum and Rickettsia helvetica in Ixodes ricinus ticks in seven study areas in Sweden. Parasit. Vectors 3, 66. doi: 10.1186/1756-3305-3-66

Shaw, S. E., Binns, S. H., Birtles, R. J., Day, M. J., Smithson, R., and Kenny, M. J. (2005). Molecular evidence of tick-transmitted infections in dogs and cats in the United Kingdom. Vet. Rec. 157, 645-648.

Shpynov, S., Fournier, P.-E., Rudakov, N., Tarasevich, I., and Raoult, D. (2006). Detection of members of the genera Rickettsia, Anaplasma and Ehrlichia in ticks collected in the Asiatic part of Russia. Ann. N.Y. Acad. Sci. 1078, 378-383. doi: 10.1196/annals.1374.075

Shukla, S. K., Vandermause, M. F., Belongia, E. A., Reed, K. D., Paskewitz, S. M., and Kazmierczak, J. (2003). Importance of primer specificity for PCR detection of Anaplasma phagocytophila among Ixodes scapularis ticks from Wisconsin. J. Clin. Microbiol. 41, 4006. doi: 10.1128/JCM.41.8.4006.2003

Silaghi, C., Gilles, J., Höhle, M. Fingerle, V., Just, F. T., and Pfister, K. (2008). Anaplasma phagocytophilum infection in Ixodes ricinus, Bavaria, Germany. Emerg. Infect. Dis. 14, 972-974. doi: 10.3201/eid1406.071095

Silaghi, C., Hamel, D., Pfister, K., and Rehbein, S. (2011a). Babesia species and co-infection with Anaplasma phagocytophilum in free-ranging ungulates from Tyrol, Austria. Wien. Tierärztl. Monatsschr. 98 268-274.

Silaghi, C., Hamel, D., Thiel, C., Pfister, K., Passos, L. M., and Rehbein, S. (2011b). Genetic variants of Anaplasma phagocytophilum in wild caprine and cervid ungulates from the Alps in Tyrol, Austria. Vector Borne Zoonotic Dis. 11, 355-362. doi: 10.1089/vbz.2010.0051

Silaghi, C., Kauffmann, M., Passos, L. M. F., Pfister, K., and Zweygarth, E. (2011c). Isolation, propagation and preliminary characterisation of Anaplasma phagocytophilum from roe deer (Capreolus capreolus) in the tick cell line IDE8. Ticks Tick Borne Dis. 2, 204-208. doi: 10.1016/j.ttbdis.2011.09.002

Silaghi, C., Liebisch, G., and Pfister, K. (2011d). Genetic variants of Anaplasma phagocytophilum from 14 equine granulocytic anaplasmosis cases. Parasit. Vectors 4:161. doi: 10.1186/1756-3305-4-161

Silaghi, C., Scheuerle, M. C. Friche Passos, L. M., Thiel, C., and Pfister, K. (2011e). PCR detection of Anaplasma phagocytophilum in goat flocks in an area endemic for tick-borne fever in Switzerland. Parasite 18, 57-62. doi: 10.1051/parasite/2011181057

Silaghi, C., Skuballa, J., Thiel, C. Pfister, K., Petney, T., Pfäffle, M., et al. (2012a). The European hedgehog (Erinaceus europaeus) - a suitable reservoir for variants of Anaplasma phagocytophilum. Ticks Tick Borne Dis. 3, 49-54. doi: 10.1016/j.ttbdis.2011.11.005

Silaghi, C., Woll, D., Hamel, D., Pfister, K., Mahling, M., and Pfeffer, M. (2012b). Babesia spp. and Anaplasma phagocytophilum in questing ticks, ticks parasitizing rodents and the parasitized rodents

- Analyzing the host-pathogenvector interface in a metropolitan area. Parasit. Vectors 5:191. doi: 10.1186/1756-3305-5-191

Sixl, W., Petrovec, M., Marth, E., Wust, G., Stunzner, D., Schweiger, R., et al. (2003). Investigation of Anaplasma phagocytophila infections in Ixodes ricinus and Dermacentor reticulatus ticks in Austria. Ann. N.Y. Acad. Sci. 990, 94-97. doi: 10.1111/j.17496632.2003.tb07343.x

Skarphedinsson, S., Jensen, P. M., and Kristiansen, K. (2005). Survey of tickborne infections in Denmark. Emerg. Infect. Dis. 11, 1055-1061. doi: 10.3201/eid1107.041265

Skarphedinsson, S., Lyholm, B. F., Ljungberg, M., Sogaard, P., Kolmos, H. J., and Nielsen, L. P. (2007). Detection and identification of Anaplasma phagocytophilum, Borrelia burgdorferi, and Rickettsia helvetica in Danish Ixodes ricinus ticks. APMIS 115, 225-230. doi: 10.1111/j.16000463.2007.apm_256.x

Skotarczak, B., Rymaszewska, A., Wodecka, B., and Sawczuk, M (2003). Molecular evidence of coinfection of Borrelia burgdorferi sensu lato, human granulocytic ehrlichiosis agent, and Babesia microti in ticks from northwestern Poland. J. Parasitol. 89, 194-196. doi: 10.1645/00223395089[0194:MEOCOB]2.0.CO;2

Skotarczak, B., Rymaszewska, A., Wodecka, B., Sawczuk, M., Adamska, M., and Maciejewska, A. (2006). PCR detection of granulocytic Anaplasma and Babesia in Ixodes ricinus ticks and birds in west-central Poland. Ann. Agric. Environ. Med. 13, 21-23.

Skuballa, J., Petney, T., Pfäffle, M. and Taraschewski, H. (2010). Molecular detection of Anaplasma phagocytophilum in the European hedgehog (Erinaceus europaeus) and its ticks. Vector Borne Zoonotic Dis. 10, 1055-1057. doi: 10.1089/vbz.2009.0150

Smetanová, K., Schwarzová, K., and Kocianová, E. (2006). Detection of Anaplasma phagocytophilum, Coxiella burnetii, Rickettsia spp., and Borrelia burgdorferi s. 1. in 
Ticks, and wild-living animals in western and middle Slovakia. Ann. N.Y. Acad. Sci. 1078, 312-315. doi: 10.1196/annals.1374.058

Smrdel, K. S., Serdt, M., Duh, D., Knap, N., and Županc, T. A. (2010). Anaplasma phagocytophilum in ticks in Slovenia. Parasit. Vectors 3:102. doi: 10.1186/1756-3305-3-102

Soleng, A., and Kjelland, V. (2013). Borrelia burgdorferi sensu lato and Anaplasma phagocytophilum in Ixodes ricinus ticks in Bronnoysund in northern Norway. Ticks Tick Borne Dis. 4, 218-221. doi: 10.1016/j.ttbdis.2012.11.006

Sonenshine, D. E. (1993). Biology of Ticks. Vol 2. New York, NY: Oxford University Press.

Spielman, A., Wilson, M. L., Levine, J. F., and Piesman, J. (1985). Ecology of Ixodes dammini-borne human babesiosis and Lyme disease. Annu. Rev. Entomol. 30, 439-460.

Špitalská, E., Boldis, V., Kostanová, Z., Kocianová, E., and Stefanidesová, K. (2008). Incidence of various tickborne microorganisms in rodents and ticks of central Slovakia. Acta Virol. 52, 175-179.

Stafford, K. C. 3rd., Massung, R. F., Magnarelli, L. A., Ijdo, J. W., and Anderson, J. F. (1999). Infection with agents of human granulocytic ehrlichiosis, lyme disease, and babesiosis in wild white-footed mice (Peromyscus leucopus) in Connecticut. J. Clin. Microbiol. 37, 2887-2892.

Stanczak, J., Gabre, R. M., KruminisLozowska, W., Racewicz, M., and Kubica-Biernat, B. (2004). Ixodes ricinus as a vector of Borrelia burgdorferi sensu lato, Anaplasma phagocytophilum and Babesia microti in urban and suburban forests. Ann. Agric. Environ. Med. 11, 109-114.

Stanczak, J., Racewicz, M., KruminisLozowska, W., and Kubica-Biernat, B. (2002). Coinfection of Ixodes ricinus (Acari: Ixodidae) in northern Poland with the agents of Lyme borreliosis (LB) and human granulocytic ehrlichiosis (HGE). Int. J. Med. Microbiol. 291(Suppl. 33), 198-201. doi: 10.1016/S1438-422180045-5

Stefanidesová, K., Kocianová, E., Boldis, V., Kostanová, Z., Kanka, P., Nemethová, D., et al. (2008). Evidence of Anaplasma phagocytophilum and Rickettsia helvetica infection in free-ranging ungulates in central Slovakia. Euro. J. Wildl. Res. 54, 519-524. doi: 10.1007/s10344-007-0161-8

Steiner, F. E., Pinger, R. R., Vann, C. N., Abley, M. J., Sullivan, B., Grindle, N., et al. (2006). Detection of Anaplasma phagocytophilum and Babesia odocoilei DNA in Ixodes scapularis (Acari: Ixodidae) collected in Indiana. J. Med. Entomol. 43, 437-442. doi: 10.1603/00222585043[0437:DOAPAB]2.0.CO;2

Steiner, F. E., Pinger, R. R., Vann, C. N., Grindle, N., Civitello, D., Clay, K., et al. (2008). Infection and co-infection rates of Anaplasma phagocytophilum variants, Babesia spp., Borrelia burgdorferi, and the rickettsial endosymbiont in Ixodes scapularis (Acari: Ixodidae) from sites in Indiana, Maine, Pennsylvania, and Wisconsin. J. Med. Entomol. 45, 289-297. doi: 10.1603/0022258545[289:IACROA]2.0.CO;2

Stuen, S. (2003). Anaplasma Phagocytophilum (Formerly Ehrlichia phagocytophila) Infection in Sheep and Wild Ruminants in Norway. A study on clinical manifestation, distribution and persistence. Dr Philos thesis, Norwegian School of Veterinary Science, Oslo.

Stuen, S., Artursson, K., and Olsson Engvall, E. (1998). Experimental infection of lambs with an equine granulocytic Ehrlichia species resembling the agent that causes human granulocytic ehrlichiosis (HGE). Acta Vet. Scand. 39, 491-497.

Stuen, S., Handeland, K., Frammarsvik, T., and Bergstrom, K. (2001). Experimental Ehrlichia phagocytophila infection in red deer (Cervus elaphus). Vet. Rec. 149, 390-392. doi: $10.1136 /$ vr.149.13.390

Stuen, S., Hardeng, F., and Larsen, H. J. (1992). Resistance to tickborne fever in young lambs. Res. Vet. Sci. 52, 211-216. doi: 10.1016/0034528890012-Q

Stuen, S., Pettersen, K. S., Granquist, E. G., Bergström, K., Bown, K. J., and Birtles, R. J. (2013). Anaplasma phagocytophilum variants in sympatric red deer (Cervus elaphus) and sheep in southern Norway. Ticks Tick Borne Dis. 4, 197-201. doi: 10.1016/j.ttbdis.2012.11.014

Stuen, S., Scharf, W., Schauer, S., Freyburger, F., Bergstrom, K., and von Loewenich, F. D. (2010). Experimental infection in lambs with a red deer (Cervus elaphus) isolate of Anaplasma phagocytophilum. J. Wildl. Dis. 46, 803-809.

Stuen, S., Torsteinbo, W. O., Bergstrom, K., and Bardsen, K. (2009). Superinfection occurs in Anaplasma phagocytophilum infected sheep irrespective of infection phase and protection status. Acta Vet. Scand. 51:41. doi: 10.1186/1751-0147-51-41
Stuen, S., Van De Pol, I., Bergström, K., and Schouls, L. M. (2002). Identification of Anaplasma phagocytophila (formerly Ehrlichia phagocytophila) variants in blood from sheep in Norway. J. Clin. Microbiol. 40, 3192-3197. doi 10.1128/JCM.40.9.3192-3197.2002

Subramanian, G., Sekeyova, Z., Raoult, D., and Mediannikov, O. (2012). Multiple tick-associated bacteria in Ixodes ricinus from Slovakia. Ticks Tick Borne Dis. 3, 406-410. doi: 10.1016/j.ttbdis.2012.10.001

Sukumaran, B., Ogura, Y., Pedra, J. H. F., Kobayashi, K. S., Flavell, R. A., and Fikrig, E. (2012) Receptor interacting protein2 contributes to host defense against Anaplasma phagocytophilum infection. FEMS Immunol. Med. Microbiol. 66, 211-219. doi: 10.1111/j.1574-695X.2012.01001.x

Swanson, K. I., and Norris, D. E. (2007). Co-circulating microorganisms in questing Ixodes scapularis nymphs in Maryland. J. Vector Ecol. 32, 243-251. doi: 10.3376/1081171032[243:CMIQIS]2.0.CO;2

Sytykiewicz, H., Karbowiak, G., Hapunik, J., Szpechcinski, A., Supergan-Marwicz, M., Golawska, S., et al. (2012). Molecular evidence of Anaplasma phagocytophilum and Babesia microti co-infections in Ixodes ricinus ticks in central-eastern region of Poland. Ann. Agri. Environ. Med. 19, 45-49.

Taylor, S. M., and Kenny, J. (1980). The effects of tick-borne fever (Ehrlichia phagocytophila) on the growth rate of fattening cattle. Brit. Vet. J. 136 , 364-370.

Teglas, M. B., and Foley, J. (2006). Differences in the transmissibility of two Anaplasma phagocytophilum strains by the North American tick vector species, Ixodes pacificus and Ixodes scapularis (Acari: Ixodidae) Exp. Appl. Acarol. 38, 47-58. doi 10.1007/s10493-005-5293-5

Teglas, M., Matern, E., Lein, S., Foley, P., Mahan, S. M., and Foley, J. (2005). Ticks and tick-borne disease in Guatemalan cattle and horses. Vet. Parasitol. 131, 119-127. doi: 10.1016/j.vetpar.2005.04.033

Telford, S. R. 3rd., Dawson, J. E., Katavolos, P., Warner, C. K. Kolbert, C. P., and Persing, D. H. (1996). Perpetuation of the agent of human granulocytic ehrlichiosis in a deer tick-rodent cycle. Proc. Natl. Acad. Sci. U.S.A. 93, 6209-6214. doi: 10.1073/pnas.93.12.6209

Tomanovic, S., Chochlakis, D. Radulovic, Z., Milutinovic, M., Cakic, S., Mihaljica, D., et al.
(2013). Analysis of pathogen co-occurrence in host-seeking adult hard ticks from Serbia. Exp. Appl. Acarol. 59, 367-376. doi: 10.1007/s10493-012-9597-y

Tomanovic, S., Radulovic, Z. Masuzawa, T., and Milutinovic, M. (2010). Coexistence of emerging bacterial pathogens in Ixodes ricinus ticks in Serbia. Parasite 17, 211-217. doi: 10.1051/parasite/2010173211

Tomasiewicz, K., Modrzewska, R., Buczek, A., Stanczak, J., and Maciukajc, J. (2004). The risk of exposure to Anaplasma phagocytophilum infection in Mid-Eastern Poland. Ann. Agric. Environ. Med. 11, 261-264.

Torina, A., Alongi, A., Naranjo, V., Estrada-Pena, A., Vicente, J., Scimeca, S., et al. (2008a). Prevalence and genotypes of Anaplasma species and habitat suitability for ticks in a Mediterranean ecosystem. Appl. Environ. Microbiol. 74, 7578-7584. doi: 10.1128/AEM.01625-08

Torina, A., Alongi, A., Naranjo, V., Scimeca, S., Nicosia, S., Di Marco, V., et al. (2008b). Characterization of Anaplasma infections in Sicily, Italy. Ann. N.Y. Acad. Sci. 1149, 90-93. doi: 10.1196/annals.1428.065

Torina, A., Galindo, R. C., Vicente, J., Di Marco, V., Russo, M., Aronica, V., et al. (2010). Characterization of Anaplasma phagocytophilum and $A$. ovis infection in a naturally infected sheep flock with poor health condition. Trop. Anim. Health Prod. 42, 1327-1331. doi: 10.1007/s11250-010-9580-8

Troese, M. J., Kahlon, A., Ragland, S. A., Ottens, A. K., Ojogun, N., Nelson, K. T., et al. (2011). Proteomic analysis of Anaplasma phagocytophilum during infection of human myeloid cells identifies a protein that is pronouncedly upregulated on the infectious dense-cored cell. Infect. Immun. 79, 4696-4707. doi: 10.1128/ IAI.05658-11

Tuomi, J. (1967a). Experimental studies on bovine tick-borne fever. 1 . Clinical and haematological data, some properties of the causative agent, and homologous immunity. Acta Pathol. Microbiol. Scand. 70, 429-445. doi: 10.1111/j.16990463.1967.tb01311.x

Tuomi, J. (1967b). Experimental studies on bovine tick-borne fever. 2. Differences in virulence of strains in cattle and sheep. Acta Pathol. Microbiol. Scand. 70, 577-589. doi: 10.1111/j.16990463.1967.tb01327.x 
Tuomi, J., and von Bonsdorff, C. H. (1966). Electron microscopy of tick-borne fever agent in bovine and ovine phagocytizing leukocytes. J. Bacteriol. 92, 1478-1492.

Tyzzer, E. E. (1938). Cytoecetes microti, n.g., n.sp., a parasite developing in granulocytes and infective for small rodents. Parasitology 30, 242-257. doi: $10.1017 /$ S0031182000025774

Uehlinger, F. D., Clancey, N. P., and Lofstedt, J. (2011). Granulocytic anaplasmosis in a horse from Nova Scotia caused by infection with Anaplasma phagocytophilum. Can. Vet. J. 52, 537-540.

Vázquez, L., Panadero, R., Dacal, V., Pato, F. J., López, C., Díaz, P., et al. (2011). Tick infestation (Acari: Ixodidae) in roe deer (Capreolus capreolus) from northwestern Spain: population dynamics and risk stratification. Exp. Appl. Acarol. 53, 399-409.

Veronesi, F., Galuppi, R., Tampieri, M. P., Bonoli, C., Mammoli, R., and Piergili Fioretti, D. (2011). Prevalence of Anaplasma phagocytophilum in fallow deer (Dama dama) and feeding ticks from an Italy preserve. Res. Vet. Sci. 90, 40-43. doi: 10.1016/j.rvsc.2010.05.019

Vichová, B., Majlathová, V., Nováková, M., Straka, M., and Pet'ko, B. (2010). First molecular detection of Anaplasma phagocytophilum in European brown bear (Ursus arctos). Vector Borne Zoonotic Dis. 10, 543-545. doi: 10.1089/vbz.2009.0103

Villeneuve, A., Goring, J., Marcotte, L., and Overvelde, S. (2011). Seroprevalence of Borrelia burgdorferi, Anaplasma phagocytophilum, Ehrlichia canis, and Dirofilaria immitis among dogs in Canada. Can. Vet. J. 52, 527-530

von Loewenich, F. D., Baumgarten, B. U., Schroppel, K., Geissdorfer, W., Rollinghoff, M., and Bogdan, C. (2003). High diversity of ankA sequences of Anaplasma phagocytophilum among Ixodes ricinus ticks in Germany. J. Clin. Microbiol. 41, 5033-5040. doi: 10.1128/JCM.41.11.5033-5040.2003 von Stedingk, L. V., Gurtelschmid, M., Hanson, H. S., Gustafson, R., Dotevall, L., Engvall, E. O., et al. (1997). The human granulocytic ehrlichiosis (HGE) agent in Swedish ticks. Clin. Microbiol. Infect. 3, 573-574. doi: 10.1111/j.14690691.1997.tb00311.x

Vor, T., Kiffner, C., Hagedorn, P., Niedrig, M., and Rühe, F. (2010). Tick burden on European roe deer (Capreolus capreolus). Exp.
Appl. Acarol. 51, 405-417. doi: 10.1007/s10493-010-9337-0

Walk, S. T., Xu, G., Stull, J. W., and Rich, S. M. (2009). Correlation between tick density and pathogen endemicity, New Hampshire. Emerg. Infect. Dis. 15, 585-587. doi: 10.3201/eid1504.080940

Walker, A. R., Alberdi, M. P., Urquhart, K. A., and Rose, H. (2001). Risk factors in habitats of the tick Ixodes ricinus influencing human exposure to Ehrlichia phagocytophila bacteria. Med. Vet. Entomol. 15, 40-49. doi: 10.1046/j.1365-2915.2001.00271.x

Walls, J. J., Greig, B., Neitzel, D. F., and Dumler, J. S. (1997). Natural infection of small mammal species in Minnesota with the agent of human granulocytic ehrlichiosis. J. Clin. Microbiol. 35, 853-855.

Wang, X. Q., Kikuchi, T., and Rikihisa, Y. (2006). Two monoclonal antibodies with defined epitopes of P44 major surface proteins neutralize Anaplasma phagocytophilum by distinct mechanisms. Infect. Immun. 74, 1873-1882. doi: 10.1128/IAI.74.3.1873-1882.2006

Webster, K. A., and Mitchell, G. B. B. (1988). Use of counter immunoelectrophoresis in detection of antibodies to tickborne fever. Res. Vet. Sci. 45, 28-30.

Wicki, R., Sauter, P., Mettler, C., Natsch, A., Enzler, T., Pusterla, N., et al. (2000). Swiss Army Survey in Switzerland to determine the prevalence of Francisella tularensis, members of the Ehrlichia phagocytophila genogroup, Borrelia burgdorferi sensu lato, and tick-borne encephalitis virus in ticks. Eur. J. Clin. Microbiol. Infect. Dis. 19, 427-432. doi: 10.1007/s100960000283

Wielinga, P. R., Gaasenbeek, C., Fonville, M., de Boer, A., de Vries, A., Dimmers, W., et al. (2006). Longitudinal analysis of tick densities and Borrelia, Anaplasma, and Ehrlichia infections of Ixodes ricinus ticks in different habitat areas in The Netherlands. Appl. Environ. Microbiol. 72, 7594-7601. doi: 10.1128/AEM.01851-06

Willardsen, P. (2004). Anti-tick vaccines. Parasitology 129, S367-S387. doi: $10.1017 / S 0031182003004657$

Wilson, M. L., Telford, S. R., Piesman, J., and Spielman, A. (1988) Reduced abundance of immature Ixodes dammini (Acari: Ixodidae) following elimination of deer. J. Med. Entomol. 25, 224-228.

Wójcik-Fatla, A., Szymañska, J., Wdowiak, L., Buczek, A., and Dutkiewicz, J. (2009). Coincidence of three pathogens (Borrelia burgdorferi sensu lato, Anaplasma phagocytophilum and Babesia microti) in Ixodes ricinus ticks in the Lublin macroregion. Ann. Agric Environ. Med. 16, 151-158.

Woldehiwet, Z. (2007). "Tickborne diseases," in Diseases of Sheep, 4th Edn. ed I. D. Aitken (Oxford: Blackwell publishing), 347-355.

Woldehiwet, Z. (2010).The natural history of Anaplasma phagocytophilum. Vet. Parasitol. 167, 108-122. doi: 10.1016/j.vetpar.2009.09.013

Woldehiwet, Z., Horrocks, B. K., Scaife, H., Ross, G., Munderloh, U. G. Bown, K., et al. (2002). Cultivation of an ovine strain of Ehrlichia phagocytophila in tick cell cultures. J. Comp. Pathol. 127, 142-149. doi: 10.1053/jcpa.2002.0574

Woldehiwet, Z., and Scott, G. R (1993). "Tick-borne (pasture) fever," in Rickettsial and Chlamydial Diseases of Domestic Animals, eds Z. Woldehiwet and $\mathrm{M}$ Ristic (Oxford: Pergamon Press), 233-254.

Woldehiwet, Z., and Yavari, C. (2012). Evaluation of an indirect enzymelinked immunosorbent assay (ELISA) for the detection of antibodies against Anaplasma phagocytophilum in sheep. J. Comp. Pathol. 146, 116-121. doi: 10.1016/j.jcpa.2011.04.004

Wuritu, Ozawa, Y., Gaowa, Kawamori, F., Masuda, T., Masuzawa, T. et al. (2009). Structural analysis of a $p 44 / m s p 2$ expression site of Anaplasma phagocytophilum in naturally infected ticks in Japan. J. Med. Microbiol. 58, 1638-1644 doi: 10.1099/jmm.0.011775-0

Xiong, Q. M., Wang, X. Q., and Rikihisa, Y. (2007). High-cholesterol diet facilitates Anaplasma phagocytophilum infection and up-regulates macrophage inflammatory protein2 and CXCR2 expression in apolipoprotein E-deficient mice. J. Infect. Dis. 195, 1497-1503. doi $10.1086 / 514819$

Yabsley, M. J., Murphy, S. M., Luttrell, M. P., Little, S. E., Massung, R. F., Stallknecht, D. E., et al. (2008). Experimental and field studies on the suitability of raccoons (Procyon lotor) as hosts for tickborne pathogens. Vector Borne Zoonotic Dis. 8, 491-503. doi 10.1089/vbz.2007.0240

Yago, T., Leppanen, A., Carlyon, J. A., Akkoyunlu, M., Karmakar, S., Fikrig, E., et al. (2003). Structurally distinct requirements for binding of P-selectin glycoprotein ligand-1 and sialyl Lewis $\mathrm{x}$ to Anaplasma phagocytophilum and P-selectin.
J. Biol. Chem. 278, 37987-37997. doi: 10.1074/jbc.M305778200

Yang, J., Liu, Z., Guan, G., Liu, Q., Li, Y., Chen, Z., et al. (2013). Prevalence of Anaplasma phagocytophilum in ruminants, rodents and ticks in Gansu, north-western China. J. Med. Microbiol. 62, 254-258. doi: 10.1099/jmm.0.046771-0

Yaxue, Z., Hongtao, J., Qiuyue, W., Zhixin, F., Hongwei, G., Pengpeng, L., et al. (2011). Molecular detection of Anaplasma phagocytophilum in Ixodid ticks in Hebei Province, China. Vector Borne Zoonotic Dis. 11, 1323-1327. doi: 10.1089/vbz.2010.0253

Ybañez, A. P., Matsumoto, K., Kishimoto, T., Yokoyama, N., and Inokuma, H. (2012). Dual presence of Anaplasma phagocytophilum and its closely related Anaplasma sp. in ixodid ticks in Hokkaido, Japan, and their specific molecular detection. J. Vet. Med. Sci. 74, 1551-1560.

Ybañez, A. P., Tagawa, M., Matsumoto, K., Kishimoto, T., Yokoyama, N., and Inokuma, H. (2013). Specific molecular detection of Anaplasma sp. closely related to Anaplasma phagocytophilum in Ixodid ticks and cattle in a pastureland in Hokkaido, Japan. Vector Borne Zoonotic Dis. 13, 6-11.

Yoshiie, K., Kim, H. Y., Mott, J., and Rikihisa, Y. (2000). Intracellular infection by the human granulocytic ehrlichiosis agent inhibits human neutrophil apoptosis. Infect. Immun. 68, 1125-1133. doi 10.1128/IAI.68.3.1125-1133.2000

Yoshimoto, K., Matsuyama, Y., Matsuda, H., Sakamoto, L., Matsumoto, K., Yokoyama, N., et al. (2010). Detection of Anaplasma bovis and Anaplasma phagocytophilum DNA from Haemaphysalis megaspinosa in Hokkaido, Japan. Vet. Parasitol. 168, 170-172. doi: 10.1016/j.vetpar.2009.10.008

Zeidner, N. S., Burkot, T. R., Massung, R., Nicholson, W. L., Dolan, M. C., Rutherford, J. S., et al. (2000). Transmission of the agent of human granulocytic ehrlichiosis by Ixodes spinipalpis ticks: evidence of an enzootic cycle of dual infection with Borrelia burgdorferi in Northern Colorado. J. Infect. Dis. 182, 616-619. doi: 10.1086/ 315715

Zele, D., Avbersek, J., Gruntar, I., Ocepek, M., and Vengust, G. (2012). Evidence of Anaplasma phagocytophilum in game animals from Slovenia. Acto Vet. Hung. 60, 441-448. doi: 10.1556/AVet.2012.038 
Zeman, P., and Pecha, M. (2008). Segregation of genetic variants of Anaplasma phagocytophilum circulating among wild ruminants within a Bohemian forest (Czech Republic). Int. J. Med. Microbiol. 298, 203-210. doi: 10.1016/j.ijmm.2008.03.003

Zhan, L., Cao, W. C., Chu, C. Y., Jiang, B. G., Zhang, F., Liu, W., et al. (2009a). Tick-borne agents in rodents, China, 2004-2006. Emerg. Infect. Dis. 15, 1904-1908. doi: 10.3201/eid1512.081141

Zhan, L., Chu, C. Y., Zuo, S. Q., Wu, X. M., Dumler, J. S., Jia, N., et al. (2009b). Anaplasma phagocytophilum and Borrelia burgdorferi in rabbits from southeastern China. Vet. Parasitol. 162, 354-356. doi: 10.1016/j.vetpar. 2009.03.003

Zhan, L., Cao, W. C., de Vlas, S., Xie, S. Y., Zhang, P. H., Wu,
X. M., et al. (2008). A newly discovered Anaplasma phagocytophilum variant in rodents from southeastern China. Vector Borne Zoonotic Dis. 8, 369-380. doi: 10.1089/vbz.2007.0211

Zhan, L., Cao, W. C., Jiang, J. F., Zhang, X. A., Wu, X. M., Zhang, W. Y., et al. (2010). Anaplasma phagocytophilum in livestock and small rodents. Vet. Microbiol. 144, 405-408. doi: 10.1016/j.vetmic. 2010.02.018

Zhang, L., Liu, H., Xu, B., Lu, Q., Li, L., Chang, L., et al. (2012a). Anaplasma phagocytophilum infection in domestic animals in ten provinces/cities of China. Am. J. Trop. Med. Hyg. 87, 185-189. doi: 10.4269/ajtmh.2012. 12-0005

Zhang, X. C., Zhang, L. X., Li, W. H., Wang, S. W., Sun, Y. L., Wang, Y. Y., et al. (2012b). Ehrlichiosis and zoonotic anaplasmosis in suburban areas of Beijing, China. Vector Borne Zoonotic Dis. 12, 932-937. doi: 10.1089/vbz.2012.0961

Zhang, L., Wang, G., Liu, Q. Chen, C., Li, J., Long, B., et al. (2013). Molecular Analysis of Anaplasma phagocytophilum isolated from patients with febrile diseases of unknown etiology in China. PLOS ONE 8:e57155. doi: 10.1371/journal.pone.0057155

Zygner, W., Górski, P., and Wedrychowicz, H. (2009). Detection of the DNA of Borrelia afzelii, Anaplasma phagocytophilum and Babesia canis in blood samples from dogs in Warsaw. Vet. Rec 164, 465-467. doi: 10.1136/vr. 164.15.465

Conflict of Interest Statement: The authors declare that the research was conducted in the absence of any commercial or financial relationships that could be construed as a potential conflict of interest.

Received: 28 April 2013; accepted: 30 June 2013; published online: 22 July 2013.

Citation: Stuen S, Granquist EG and Silaghi C (2013) Anaplasma phagocytophilum - a widespread multihost pathogen with highly adaptive strategies. Front. Cell. Infect. Microbiol. 3:31. doi: 10.3389/fcimb.2013.00031

Copyright (C) 2013 Stuen, Granquist and Silaghi. This is an open-access article distributed under the terms of the Creative Commons Attribution License, which permits use, distribution and reproduction in other forums, provided the original authors and source are credited and subject to any copyright notices concerning any third-party graphics etc. 